\title{
A atenção à saúde da pessoa portadora de deficiência no sistema de saúde no município de São Paulo: uma questão de cidadania.
}

FATIMA CORRÊA OLIVER

Dissertação apresentada ao Departamento de Prática de Saúde Pública da Faculdade de Saúde Pública da USP, para obtenção do título de mestre em saúde pública.

Orientadora: Prof. Associado Evelin Naked de Castro Sá

São Paulo 
A Lamartine e a Olívia, que aguardaram, pacientemente, o final deste trabalho 


\section{APRESENTAÇÂO}

O motor inicial deste trabalho foi o fato de ter participado da elaboração do projeto de sistema de atendimento da saúde e reabilitação às pessoas com deficiência como membro do grupo de trabalho que o delineou. Isso acontecia no mesmo momento em que iniciava minha formação em Saúde Pública, inseria-me no programa de Mestrado na área e na carreira docente, como auxiliar de ensino do Curso de Terapia Ocupacional da USP.

Poder observar e contribuir para avaliação de uma proposta com a qual se colaborou diretamente é criar um momento de reflexão privilegiado em que, sem dúvida, repropõe uma avaliação profissional.

Também foi decisivo para a realização desse trabalho o fato de estar trabalhando há quase dez anos no serviço público, sendo que seis dos quais na assistência direta à população, mesmo que não especificamente, com a população portadora de deficiência.

O percurso de um trabalhador da saúde é muitas vezes árduo e, na maior parte do tempo, conta-se apenas com a solidariedade dos companheiros de trabalho e da população, que são capazes de transformar as condições objetivas de trabalho.

Nesta trajetória foram muitas as pessoas que percorreram o mesmo caminho em especial: Eucenir Fredini Rocha, Elisabete Ferreira Mângia e Roseli Esquerdo Lopes.

A realização deste trabalho só foi possível graças à contribuição direta das pessoas que participaram do Grupo Especial do Programa de Saúde do Deficiente e de todas aquelas 
que se dispuseram, pacientemente, a oferecer seus depoimentos.

A disponibilidade e o esforço na transcrição das fitas, de pessoas como Elisa Teixeira Rugai, Marisa Samea e Stella Maris Nicolau, deram condição objetiva de análise a tudo quanto se recolheu de informações.

Para mim é bastante difícil a transformação das ideias e reflexões em material concreto e objetivo. É difícil desprezar, ou melhor deixar de lado alguns pontos, optar por ser mais concisa. O que apresento agora como resultado dessas reflexões só se tornou palpável, real e mais objetivo graças ao trabalho conjunto, que foi permeado de uma relação muito fraternal com Evelin Naked de Castro Sá, orientadora e companheira.

Meus agradecimentos a todas essas pessoas que considero como que co-autores deste trabalho.

O Conselho Nacional de Desenvolvimento Tecnológico e Científico financiou parte dos custos deste trabalho. 
“...Há, enfim, uma terceira ótica sob a qual considerar a doença, a mais negligenciada: a doença individual quase sempre é o sintoma de fenômenos sociais de alcance mais amplo. É um sinal de alarme, que ressoa no corpo e na psique dos indivíduos. A medicina e, particularmente o hospital, fazem todo o possível para atenuá-lo como um silenciador."

Outra questão "é, a contraposição entre fenômenos biológicos e sociais e a polêmica contra a conduta terapêutica que "corta, substitui, trata este ou aquele pedaço". As vezes, isso é preciso! O tema é retomado contrapondose o que ocorre no interior do corpo e o que ocorre em torno. As vezes, perdem a conexão entre os dois fenômenos. O que acontece com o corpo é, frequentemente consequência do que acontece no ambiente. Além disso, atenuando o sofrimento, reconstituindo as funções corporais e mentais, podemos amiúde tornar mais visível o que acontece em torno e influir sobre seu desenvolvimento". 


\section{RESUMO}

A inserção da atenção à saúde da pessoa portadora de deficiência no sistema de saúde é o objeto da presente dissertação, tomando-se como universo de estudo seu desenvolvimento no Município de São Paulo.

Considera-se que o desenvolvimento dos serviços de atenção a essa população depende do delineamento das políticas sociais, que refletem diferentes concepções de cidadania.

O tema é estudado por meio da discussão das políticas sociais e suas repercussões e da análise dos depoimentos de profissionais envolvidos com a proposição e execução do atendimento à pessoa portadora de deficiência, nos serviços públicos, filantrópicos e beneficentes.

Pode-se verificar que o problema da incapacidade e da deficiência tem relevância no âmbito da saúde pública. E, ainda, que a assistência a essa população se insere marginalmente no sistema de saúde, depende do modelo assistencial proposto e do estágio de implantação do Sistema Único de Saúde que permitem revelar, no âmbito do setor saúde, a cidadania possível das pessoas portadoras de deficiência. 


\section{SUMMARY}

Bringing the problems of the health assistance to the handicapped people to the attention of the Public Health Services is the object of the present work. Its universe of study is the development of the above mentioned problem in the S. P. municipality.

We consider that the development of specific services of heath assistance to the handicapped people depends on the delineation of social policies, wich, by their turn, reflect different conceptions of citizenship.

This subject is studied through the discussion of different social policies and their repercussions, as well as through the analysis of reports made by profissionals involved with the planning and performing of the assistance to the disabled people within beneficent, philanthropic and public services.

We may observe that both the problems of disability and handicap are relevant to the Public Health Services.

We may also see that the assistance to these people inserts itself - marginally - into the Public Health Services, and depends on the proposed assistance model and on the level of implantation of the new Health System, wich allow us to unveil, within the public heath secton wich citizenship is possible to the disabled people. 
II - O PROBLEMA DA DEFICIÊNCIA E DA INCAPACIDADE 18

1 - A prevalência de incapacidades e deficiência

2 - Caracterização da população portadora de incapacidade e deficiência

3 - Acidentes de trabalho

III - OBJETIVOS

IV - UNIVERSO, METODOLOGIA E PROCEDIMENTO

V - CIDADANIA, POLITICAS SOCIAIS E O DESENVOLVIMENTO DOS SERVIÇOS DE ATENÇÃO A SAÚDE DA PESSOA PORTADORA DE DEFICIÊNCIA

1 - A questão da cidadania e as políticas sociais.

2 - A atenção à saúde como direito da pessoa portadora de deficiência e o Sistema Único de Saúde

2.1 - O direito à saúde e o Sistema Único de Saúde

2.2 - O modelo assistencial e suas repercussões

2.3 - Os serviços de atenção à população portadora de deficiência, no Município de São Paulo

2.4 - A atenção à saúde da pessoa portadora de deficiência na rede pública. Uma experiência

VI - ENTREVISTAS

1 - Apresentação e discussão

1.1 - Entrevistas realizadas com profissionais da Secretaria de Estado da Saúde

1.2 - Entrevistas realizadas com profissionais das instituições que, tradicionalmente atendem à clientela 
1.3 - Entrevistas realizadas com profissionais da área federal

1.4 - Entrevistas realizadas com profissionais da área municípal

2 - Análise dos resultados e conclusão

VII - CONSIDERAÇÕES FINAIS

VIII · BIBLIOGRAFIA

1 - Referencias bibliográficas

2 - Bibliografia consultada

\section{ANEXO}

Roteiros de Entrevistas 
1 - Pessoas deficientes e população residente, por diferentes regiões do país, 1981

2 - População deficiente e população residente, por grupos de idade, no Brasil, no Estado de São Paulo e na região metropolitana de São Paulo, 1981

3 - Pessoas deficientes, segundo tipo de deficiência ou incapacidade, no Brasil, no Estado de São Paulo e na região metropolitana de São Paulo, 1981

4 - Pessoas deficientes, por vinculação a associação ou instituição de assistência, no país, no Estado de São Paulo e na região metropolitana de São Paulo, 1981.

5 - Pessoas deficientes que receberam assistência, por tipo de assistência, no Brasil, no Estado de São Paulo e na região metropolitana de São Paulo 1981

6 - Acidentes de trabalho no Brasil, de 1978 a 1986

7 - Acidentes de trabalho liquidados na área urbana, segundo a classificação, de 1980 a 1987, Brasil

8 - Benefícios por acidentes de trabalho em cadastro, por espécie e clientela em 31/12/87

9 - Acidentes liquidados segundo a consequência, no Estado de São Paulo, 1978 a 1986 
10 - Entrevistas realizadas, segundo tipo de instituição e roteiro de entrevistas

11 - Diferentes serviços de atenção à pessoa deficiente, no município de São Paulo, 1987.

12 - Nível de implantação do atendimento à saúde da clientela, segundo as regiões de saúde da Secretaria de Estado de Saúde, no município de São Paulo , dezembro de 1989

13 - Condições de espaço físico destinado ao atendimento à saúde da clientela e de disponibilidade de profissionais contratados; segunda as regiões de saúde, no município de São Paulo, dezembro de 1989

14 - Tempo de graduação e experiência profissional dos técnicos que atendem a clientela nos SUDS, dezembro de 1989

15 - Respostas dos profissionais que atendem à clientela à questão: Qual é a sua vinculação ao programa de atendimento à pessoa portadora de deficiência, dezembro de 1989 
I - INTRODUÇÃO 
Ao apresentar e propor a discussão sobre a problemática da atenção à saúde das pessoas deficientes, depara-se com um tema extremamente complexo, que exige uma avaliação preliminar sobre o significado de ser deficiente e também sobre qual é essa população.

A OMS, Organização Mundial da Saúde, considera que mesmo que seja pouco provável que se consiga uma série de definições ideais para os termos incapacidade e deficiência, é importante que se divulgue ao máximo algumas definições operativas sobre esses termos. Então, sugere que se possa compreender que existe uma série de fenômenos ligados à doença como deficiência, incapacidade e invalidez que poderiam ser definidos como:

"deficiência: levando em conta a experiência obtida nas atividades sanitárias, deficiência é toda perda ou anormalidade da estrutura ou da função psicológica ou anatômica.

incapacidade: 
O grupo de especialistas da OMS que tem trabalhado nessa questão "adverte para o fato de que as deficiências e as incapacidades podem ser visíveis ou não, temporárias ou permanentes, regressivas ou progressivas. A invalidez não é sempre resultado de uma incapacidade, algumas vezes as deficiências causam invalidez sem passar necessariamente pela etapa intermediária da incapacidade. Além do que nas limitações individuais, em consequência de deficiência ou de incapacidade, existem fatores sociais e ambientais que podem aumentar ou reduzir os estados de invalidez." (25) A avaliação sobre a condição dessa parcela da população também é algo complexo, pois faz retomar constantemente conceitos como normalidade, anormalidade, saúde e doença, eficiência e deficiência. O estudo e discussão desses conceitos apresentam, prioritariamente, a sua condição de relação, isto é, a doença tem como parâmetro de normalidade, de respeito à norma e à regra, que representa o que é mais comum e mais aceito. A deficiência traz em sí uma condição de impossibilidade de desenvolver determinadas 
habilidades ou capacidades, a impossibilidade de ser eficiente, isto é, de dar conta de um perfil de desempenho esperado e condicionado no contexto social.

Assim, ser anormal ou deficiente pode significar possibilidades de desenvolvimento humano limitadas que se dão não apenas pelas dificuldades ou impossibilidades físicas ou mentais, mas também por aquelas advindas do contexto social (26). Dessa forma a deficiência deve ser entendida historicamente, seu significado e magnitude dependendo do contexto e manifestando-se também como problemas sociais.

A atenção à saúde das pessoas deficientes é uma das faces da problemática dessa população e caminha em estreita relação com os outros aspectos da vida dessas pessoas, como educação, lazer e inserção social.

Quando se fala em atenção à saúde da pessoa deficiente está presente a necessidade de adoção de um sistema de atenção à saúde com o objetivo de facilitar a prevenção de incapacidades e oferecer ou proporcionar oportunidades de reabilitação como direito social desse indivíduos.

Em seus textos oficiais a OMS discute a necessidade de criação de um sistema de atenção primária de saúde com o objetivo de prevenir incapacidades e criar formas de reabilitação. No entanto, o próprio órgão reconhece a dificuldade dessa tarefa e se pergunta como traduzi-la na prática dos serviços comunitários de atenção primária e como integrá-la nos sistemas nacionais de saúde e de outros setores (25). Isto porque, é reconhecida a diversidade dos estágios de desenvolvimento das políticas de saúde nos países em geral, e em especial, nos países do Terceiro 
Mundo, onde se concentra a maior parte da população mundial e, também, aquela submetida às piores condições de vida e de trabalho.

O programa de Reabilitação Baseada na Comunidade da OMS, que vem se desenvolvendo em alguns países do Terceiro Mundo, na África e na América Latina, é uma forma de incluir nos serviços de saúde e na atenção primária, as ações básicas de prevenção de incapacidades e deficiências, bem como de identificação precoce das pessoas que possam estar com seu desenvolvimento neuropsico-motor potencialmente comprometido. Também é objetivo do programa criar ações de tratamento e reabilitação em nível comunitário utilizando recursos simples e de fácil adaptação. (20)

Este trabalho pretende abordar o tema da atenção à saúde da pessoa portadora de deficiência no sistema de saúde no município de São Paulo* como uma questão de cidadania.

Apresenta no capítulo I a concepção de incapacidade, deficiência e invalidez da Organização Mundial da Saúde - OMS e a atenção à saúde das pessoas portadoras de deficiência como um dos aspectos da problemática dessas pessoas.

No capítulo II aponta os problemas da incapacidade e da deficiência com base em dados estatísticos disponíveis, mesmo que de 1981. Ressalta a importância dos acidentes de trabalho na constituição das estimativas de população com incapacidade ou deficiência.

\footnotetext{
* para a realização deste trabalho levou-se em conta os limites geográficos desse município e os serviços de saúde nele situados. É importante salientar que os seus equipamentos sociais atendem à população de quase toda a região metropolitana e que isso lhes confere características próprias.
} 
Nos capítulos III e IV apresenta os objetivos do estudo e os procedimentos utilizados respectivamente.

No capítulo $V$ aponta a questão da atenção à saúde da população portadora de deficiência como aspecto importante da cidadania dessas pessoas apresentando os textos constitucionais federal, estadual e alguns dispositivos legais que tratam do tema, avaliando-os com base no desenvolvimento das políticas sociais em especial da saúde.

No capítulo VI apresenta e analisa as entrevistas realizadas nos diferentes serviços de saúde que atendem essa população, ilustrando assim os aspectos já levantados da assistência a essa população, isto é, a quase que inexistência de serviços dirigidos a essas pessoas e as dificuldades de implantação de proposta de atendimento a uma população que, tradicionalmente, não é atendida pelos serviços públicos.

No capítulo VII são apresentadas as considerações finais e algumas sugestões para melhor entender e operacionalizar a constituição de ações de saúde junto a essa população. 
II - O PROBLEMA DA DEFICIÊNCIA E DA INCAPACIDADE 
Neste capítulo procurar-se-á caracterizar o problema da deficiência e incapacidade a partir da apresentação de alguns dos dados disponíveis relativos à distribuição das pessoas incapacitadas ou portadoras de deficiência na população em geral.

A incidência e prevalência das incapacidades e deficiências serão apresentadas em termos estimativos, exploratórios e com base em alguns dados estatísticos. Segundo a própria OMS, “...uma cifra de $10 \%$ seria a proporção de pessoas incapacitadas entre a população mundial..." e "que...aproximadamente $1,5 \%$ do total consta que sejam pessoas incapacitadas que poderiam receber o benefício de reabilitação" (25).

Isto significa que "só na Cidade de São Paulo deve haver por volta de 1,5 milhões de deficientes e no Estado cerca de 03 milhões. Além disso, se considerarmos a constelação familiar, pode-se calcular em 12 milhões o número de pessoas envolvidas, direta ou indiretamente com a questão da deficiência" (33).

PANTANO (26) na Argentina, refere que a tarefa de quantificação das pessoas com deficiência ou incapacidade é um problema internacional que se coloca, inclusive, pela dificuldade de reconhecimento das pessoas que estão comprometidas. Assim, sugere que os levantamentos e estudos devam ser utilizados como instrumentos para avaliar e priorizar ações específicas. A autora faz em seu trabalho referência a diversos levantamentos de população de diferentes países. No caso da Argentina especificamente, a autora refere que é antiga a preocupação em obter esses dados, tanto que eles aparecem em diferentes censos, desde 1869, porém em cada um deles com problemas diferentes, 
dificultando um melhor uso sequencial dos mesmos.

No México, IBARRA (21) informa que existe um Registro Nacional de Inválidos do qual analisou 24.375 casos novos registrados no período de 1975 a 1978. Os dados do Registro foram coletados junto a diferentes dos casos que chegaram até os serviços em busca de atendimento. Ou seja, vem existindo uma preocupação crescente com a identificação e conhecimento da população que apresente algum tipo de incapacidade ou deficiência.

Sabemos que as principais causas de deficiências incapacitantes, nos países em desenvolvimento, estão ligadas às condições de vida impostas à maior parte da população, pelo modelo econômico predominante, que é altamente concentrador de renda, e que apresenta as prioridades de caráter social como mero discurso.

Assim, aparecem como principais causas de deficiência as consequências na área da saúde, desse modelo concentrados: má nutrição, alto índice de doenças transmissíveis, baixa qualidade de assistência pré, peri e pós-natal, altos índices de acidentes de trabalho entre outras.

A própria OMS (25) declara que nos países desenvolvidos as causas de incapacidades estão restritas às áreas de concentração da população urbana mais pobre. Nesses países os acidentes aparecem como responsáveis pelo aumento do número das incapacidades, ao lado daquelas incapacidades advindas do processo de envelhecimento, decorrentes de uma esperança de vida maior e dos avanços conseguidos na assistência médica. 
No Brasil, pela conformação de seu modelo econômico e pelas características do desenvolvimento do processo de atenção à saúde, percebe-se um perfil epidemiológico que reflete tanto as condições que favorecem 0 aparecimento de doenças $e$ incapacidades dos países em desenvolvimento quanto, aquelas de países desenvolvidos, ou seja altas taxas de morbi-mortalidade por doenças crônico-degenerativas, cardiovasculares, doenças do trabalho e acidentes.

\section{1 - A Prevalência de Incapacidades e Deficiência}

No Brasil, são poucos os estudos de que se dispõe sobre prevalência de incapacidades. É importante considerar essa prevalência a partir do reconhecimento da existência de condições objetivas de vida e trabalho que são resultado do tipo de inserção social possível num determinado período histórico.

Esse reconhecimento implica assumir que as doenças ou os agravos à saúde, inclusive as incapacidades, distribuem-se de forma diferenciada nos grupos sociais.

Assim, é bastante esclarecedor o resultado da pesquisa realizada em 1985 por SANTOS JR. e LESSA (28), na cidade de Salvador, sobre a prevalência de incapacidades em dois diferentes grupos sociais. Segundo os pesquisadores, que estudaram moradores favelados e não favelados, a partir dos 7 anos de idade, "a prevalência global de incapacidade foi de $8,0 \%$ para os favelados e de $\mathbf{2 , 5 \%}$ para os não favelados. As principais causas para os favelados são incapacidades física $(6,2 \%)$ e mental (1,8\%) enquanto que para os não favelados as prevalências foram de $1,9 \%$ e $0,7 \%$, respectivamente. As prevalências foram de 1,9\% e $0,7 \%$ respectivamente. As prevalências foram maiores para os homens favelados em relação às mulheres do mesmo grupo, 
enquanto que entre os não favelados não houve diferença de sexo. As incapacidades do aparelho locomotor foram mais prevalentes, seguindo-se as mentais e as dos órgãos dos sentidos" (28). Esta pesquisa demonstrou a relação entre as incapacidade e os diferentes grupos sociais.

No Brasil, os dados estatísticos gerais, de que se dispõe sobre deficiência, foram coletados pela Fundação Instituto Brasileiro de Geografia e Estatística-IBGE, através da Pesquisa Nacional por Amostra de Domicílios de 1981, PNAD 81. Este também foi o Ano Internacional da Pessoa Deficiente.

Nesse ano, a pesquisa priorizou a coleta de dados sobre saúde, incluindo levantamento sobre deficientes segundo os critérios que a seguir estão transcritos:

“Em relação às pessoas portadoras de deficiências, segundo a percepção do entrevistado, foi indagada a natureza da deficiência, o tipo de assistência recebida e vinculação a alguma associação ou instituição."

As deficiências relatadas foram classificadas dentro das seguintes categorias:

Cegueira - para a pessoa que apresentava incapacidade de ver (cegueira dos dois olhos) ocasionadas por problemas de visão ou ausência dos globos oculares;

Surdez - para a pessoa que apresentava incapacidade de ouvir (surdez dos dois ouvidos);

Surdo - mudez - para a pessoa que apresentava incapacidade absoluta, geralmente congênita, de ouvir e que teve como consequência a incapacidade de falar. Incluído neste item o surdo - mudo readaptado (que aprendeu a falar); 
Retardamento ou doença mental - para a pessoa que apresentava problemas de retardamento do desenvolvimento mental e motor, como por exemplo, a idiotia e o mongolismo. Incluídos neste item os casos 'percebidos' pela família como sendo de atraso no desenvolvimento mental, ou referidos como excepcionais, ainda que não tenha havido diagnóstico médico. Incluídos, também, neste item os casos de loucura, ainda que sem diagnóstico médico, paranoias, esquizofrenias, etc...;

Falta de algum membro ou parte dele - para a pessoa que, por acidente ou má formação congênita, não tinha um ou vários dos membros, ou parte deles como, por exemplo, a mão inteira, todos os dedos que provocam dificuldades funcionais de maior gravidade;

Paralisia total ou das duas pernas - para pessoa tetraplégica (paralítica dos quatro membros) ou para a pessoa paraplégica (paralítica das duas pernas);

Paralisia de um lado (1 braço e/ou 1 perna) - para a pessoa que tinha um lado totalmente paralisado (1 braço e 1 perna) ou para a pessoa que tinha paralisia de apenas um membro (1 braço ou 1 perna)(15)."

Observa-se que as categorias utilizadas possibilitam a detecção dos casos mais graves de incapacidades e deficiência. Naquela pesquisa registrou-se $1,78 \%$ da população residente do Brasil como de pessoas deficientes, o que é incompatível com as estimativas da Organização Mundial da Saúde, mas pode ser compreendido como aquele percentual que demonstra os casos mais graves.

Como os dados da PNAD 81 foram coletados por instituição de reconhecido trabalho em pesquisa, acreditamos que estes podem ser utilizados com as restrições apresentadas, contribuindo para o estudo da problemática de atenção à pessoa deficiente. 


\section{2 - Caracterização da População Portadora de Incapacidade}

\section{e Deficiência}

Seguem-se alguns dados sobre pessoas deficientes quanto ao número, faixa etária, tipos de deficiência e incapacidade, vinculação à assistência médica e de reabilitação e ao mercado de trabalho, tanto no país quanto no Estado de São Paulo e na região metropolitana de São Paulo. Estes serão apresentados sob forma de 5 tabelas organizadas a partir das informações colhidas pela PNAD 81 e publicadas pela Fundação IBGE em 1983.

De acordo com a PNAD 81 pode-se observar que a distribuição da população deficiente nas diferentes regiões do país, conforme Tabela 1, obedece aproximadamente, ao mesmo percentual que 0 da população em geral.

Tabela 1 - Pessoas deficientes e população residente, por diferentes regiões do país, 1981.

\begin{tabular}{lrrrr} 
Região & $\begin{array}{l}\text { População } \\
\text { deficiente }\end{array}$ & \multicolumn{2}{l}{$\begin{array}{l}\text { População } \\
\text { residente }\end{array}$} \\
\hline Norte & 46.224 & 2,16 & 3.235 .789 & 2,70 \\
Nordeste & 672.031 & 30,10 & 35.787 .567 & 29,90 \\
Sudeste & 977.990 & 45,82 & 53.390 .972 & 44,61 \\
Sul & 336.310 & 35,75 & 19.390 .968 & 16,20 \\
Centro-oeste & 131.771 & 6,17 & 7.886 .260 & 6,59 \\
\hline Total & 2.134 .326 & 100,00 & 119.691 .556 & 100,00 \\
\hline
\end{tabular}

Fonte - Fundação IBGE (15).

No entanto, o mesmo não ocorre quando comparamos as, populações residente e deficiente por grupos de idade conforme está apresentado na Tabela 2. 
Tabela 2 - População deficiente e população residente por grupos de idade, Brasil. Estado de São Paulo, região Metropolitana SP, 1981.

\begin{tabular}{lrrrrrr}
\hline $\begin{array}{l}\text { Grupo } \\
\text { de }\end{array}$ & \multicolumn{2}{c}{ Brasil } & \multicolumn{2}{c}{ Estado SP } & \multicolumn{2}{r}{ Reg Metrop SP } \\
Idade & Def $\%$ & Def $\%$ & Pef $\%$ & Def \% & Def \% & Def $\%$ \\
\hline $00-09$ & 10,64 & 25,72 & 8,87 & 22,39 & 7,58 & 22,03 \\
$10-19$ & 18,63 & 23,28 & 17,09 & 20,88 & 17,74 & 19,81 \\
$20-29$ & 14,02 & 16,96 & 16,13 & 19,25 & 15,72 & 20,35 \\
$30-39$ & 11,53 & 12,09 & 10,03 & 13,62 & 11,61 & 14,37 \\
$40-49$ & 11,02 & 9,03 & 12,09 & 9,97 & 13,5 & 9,96 \\
$50-59$ & 10,86 & 6,56 & 11,48 & 7,23 & 12,7 & 7,28 \\
60 - + & 23,3 & 6,42 & 24,31 & 6,66 & 21,24 & 6,2 \\
TOTAL & 100 & 100 & 100 & 100 & 100 & 100 \\
\hline
\end{tabular}

FONTE: FUNDAÇÃO IBGE $(15,16,17)$

Observa-se, na Tabela 2, que entre os $0-29$ anos de idade estão $65,94 \%$ da população e $43,29 \%$ da população deficiente do país. O mesmo ocorre no Estado de São Paulo, com 42,09\% da população deficiente nessa faxia etária e na Região Metropolitana de São Paulo com 41,04\% da população deficiente nesse grupo. Isto pode significar que as deficiências ou incapacidades mais graves detectadas nessa pesquisa desenvolvem-se no decorrer do processo de trabalho e de vida.

É a partir dos 40 anos que o índices de pessoas deficientes são superiores aos da distribuiçãa da população em geral, com especial destaque para a faixa dos 60 anos e mais, o que demonstra um processo de desgaste da força de trabalho, possivelmente, decorrente das condições de vida e trabalho e não apenas do processo de envelhecimento.

$\mathrm{Na}$ Tabela 3, observa-se que no Brasil temos 31,31\% da população portadora de deficiência na categoria retardamento ou doença mental, enquanto que para as categorias que congregam 
incapacidades, prioritariamente, da funcionalidade motora definidas nos itens 5,6,7 e 8 encontra-se $41,54 \%$ das pessoas portadoras de deficiências. O mesmo ocorre para o Estado de São Paulo e para a região Metropolitana. Pode-se considerar que essas categorias apresentem os resultados mais próximos da realidade, pois são mais objetivas e, portanto, mais facilmente referidas pelos entrevistados, o que talvez não ocorra com a categoria de retardamento ou doença mental. Assim, é provável que não tenham sido referidos adequadamente os problemas de função motora ou mental de menor gravidade.

Tabela 3 - Pessoas deficientes, segundo o tipo de deficiência ou incapacidade, no Brasil, Estado de São Paulo, Região Metropolitana de São Paulo, 1981.

\begin{tabular}{|c|c|c|c|}
\hline $\begin{array}{l}\text { Tipo de deficiência } \\
\text { ou incapacidade }\end{array}$ & Brasil \% & $\begin{array}{l}\text { Pessoas def. } \\
\text { Est. São Paulo }\end{array}$ & $\begin{array}{l}\text { Reg. Metrop. } \\
\text { SP } \%\end{array}$ \\
\hline 1 - Cegueira & 8,21 & 6,81 & 6,22 \\
\hline 2 - Surdez & 8,76 & 7,9 & 6,91 \\
\hline 3 - Surdo-mudez & 4,24 & 2,35 & 1,37 \\
\hline $\begin{array}{l}4 \text { - Retardamento ou } \\
\text { doença mental }\end{array}$ & 31,31 & 33,34 & 34,9 \\
\hline $\begin{array}{l}5 \text { - Falta algum } \\
\text { membro/parte }\end{array}$ & 6,62 & 7,84 & 8,14 \\
\hline $\begin{array}{l}6 \text { - Paralisia } \\
\text { total/pernas }\end{array}$ & 5,04 & 5,14 & 3,93 \\
\hline $\begin{array}{l}7 \text { - Paralisia um } \\
\text { lado - perna }\end{array}$ & 12,2 & 11,4 & 15,34 \\
\hline $\begin{array}{l}8 \text { - Outro tipo inc. } \\
\text { paralisia }\end{array}$ & 17,68 & 20,25 & 18,2 \\
\hline 9 - + de 01 tipo & 3,94 & 4,94 & 4,39 \\
\hline Total & 100 & 100 & 100 \\
\hline
\end{tabular}

FONTE: FUNDAÇÃO IBGE $(15,16,17)$ 
Outro aspecto importante a ressaltar é a atividade econômica dessa população. No Brasil, em 1981, observa-se que $23,27 \%$ das pessoas deficientes eram economicamente ativas, enquanto que $53,41 \%$ da população brasileira era economicamente ativa nessa época (15).

No Estado de São Paulo temos 55,70\% da população geral é economicamente ativa. Essa proporção não se mantém para a população de deficientes, pois apenas $22,56 \%$ destes participam da atividade econômica (16).

O mesmo ocorre na Grande São Paulo onde temos 20,64\% da população deficiente economicamente ativa, para $55,83 \%$ da população em geral (17). Isto pode ser entendido como maior dificuldade que 0 mercado de trabalho, predominantemente industrial e de serviços, tem de absorver a população portadora de deficiência.

Quanto à vinculação dessa população à assistência pode-se observar, na Tabela 4, que o percentual de pessoas portadoras de deficiência vinculadas a associação ou instiuição de assistência varia em torno dos $8,5 \%$ a $12,0 \%$ sendo que o melhor índice de

Tabela 4 - Pessoas deficientes, por vinculação a associação ou instituição de assistência, seg, país, Estado de São Paulo - Região Metropolitana de SP, 1981.

\begin{tabular}{lccrr}
\hline Local & \multicolumn{2}{l}{$\begin{array}{l}\text { Pessoas Deficientes } \\
\text { Vinculadas Não Vinculadas }\end{array}$} & S/ declaração & \\
\hline Brasil & 8,45 & 91,49 & 0,06 & 100 \\
Estado de & 9,21 & 90,69 & 0,1 & 100 \\
$\begin{array}{l}\text { São Paulo } \\
\text { Região }\end{array}$ & 11,79 & 89,97 & 0,24 & 100 \\
metr. de SP & & & & \\
\hline
\end{tabular}

FONTE: FUNDAÇÃO IBGE $(15,16,17)$ 
$11,79 \%$ de pessoas vinculadas corresponde à Região Metropolitana de São Paulo, que dispõe de um número maior de serviços de saúde em geral, e de atenção a essa população, em particular.

$\mathrm{Na}$ tabela 5, sobre a assistência, observa-se que entre as pessoas que receberam assistência, a que é predominante é a assistência médica. Surpreende 0 fato de que na Região Metropolitana de São Paulo temos o menor índice de tratamento de reabilitação, mas isso talvez possa ser explicado pelo fato de existir um índice maior para a associação de mais de um tipo de assistência.

Ainda é importante notar que a assistência de reabilitação profissional é praticamente inexistente, o que pode ajudar a entender a vinculação dessa população a atividades econômicas como já foi colocado anteriormente.

Tabela 5 - Pessoas deficientes que receberam assistência, por tipo de assistência, no Brasil, Estado de São Paulo e Região Metropolitana de São Paulo, 1981.

\begin{tabular}{lrrrrrrr}
\hline Pessoas Deficientes que Receberam Assistência \\
\hline Loca & Médica & Trat. \\
Reab. & Reab. Outro & $\mathbf{+ 1}$ tipo S/ decl Total \\
\hline Brasil & 81,95 & 10,33 & 0,18 & 2,03 & 5,38 & 0,13 & 100 \\
Est. SP & 77,41 & 9,52 & - & 4,36 & 8,71 & - & 100 \\
Metrop. SP & 79,5 & 8,85 & - & 2,95 & 8,7 & - & 100 \\
\hline
\end{tabular}

FONTE: FUNDAÇÃO IBGE $(15,16,17)$

A apresentação axaustiva dos dados sobre as incapacidade e deficiência revela que, praticamente, inexistem oportunidades de atenção à saúde e reabilitação dessa população.

A luz do conhecimento já acumulado na área de intervenção 
em saúde podemos concluir que as categorias apresentadas como deficiência mais comuns são manifestações que exigem, na maior parte das vezes, ações de saúde interdisciplinares, seja em saúde mental, seja em reabilitação ou tratamento de disfunções físicas. Assim, trabalharemos com a hipótese de que existe insuficiência de serviços de saúde preparados para o atendimento dessa população.

O fato da grande maioria das pessoas deficientes não estarem inseridos formal ou informalmente no mercado de trabalho, também traduz a dificuldade de inserção social, que em nossa sociedade se dá prioritariamente através do trabalho. O mesmo processo de trabalho e produção, que é uma das únicas vias de inserção social, cria trabalhadores sem condições de nele permanecer, expulsa-os da produção de riqueza, deixando em seus corpos e mentes sinais dessa violência.

Vale ressaltar aqui a importância dos acidentes de trabalho como um dos fatores que determinam as condições de saúde da população e a origem de incapacidades e deficiências já apontadas anteriormente. As estatísticas desses acidentes demonstram a violência de que se reveste o processo de produção da riqueza em nosso país. A riqueza é produzida a partir da expropriação da saúde dos trabalhadores.

A seguir apresemtam-se alguns dados sobre esses acidentes no Brasil. Estes demonstram a magnitude e a importância do problema em nível de saúde pública.

\section{3 - Acidentes de Trabalho}

Conforme dados do Instituto Nacional da Previdência Social INPS, trabalhados pela Fundação Rogério Duprat Figueiredo de 
Segurança e Medicina do Trabalho - FUNDACENTRO e apresentados na tabela 6 , é flagrante a diminuição do percentual dos acidentes registrados nos períodos de 1978 a 1986, sugerindo intensificação de políticas de prevenção. No entanto, o próprio INPS reconhece que há subnotificação das declarações de acidentes de trabalho (1). Contribui para que isso ocorra, o dispositivo legal, implantado a partir de 1976, que altera a sistemática quanto à conceituação, pagamento de benefícios e normas de registro de acidentes (13).

Tabela 6 - Estatística de acidentes de trabalho ocorridos no Brasil, no período de 1978 a 1986.

\begin{tabular}{rrrr}
\hline Ano & \multicolumn{1}{l}{$\begin{array}{l}\text { № de trab. } \\
\text { segurados }\end{array}$} & \multicolumn{1}{l}{$\begin{array}{l}\text { № de acid. } \\
\text { ocorridos }\end{array}$} & Porcentagem \\
\hline 1978 & 17.108 .237 & 1.551 .501 & 9,09 \\
1979 & 18.134 .731 & 1.444 .627 & 7,97 \\
1980 & 19.222 .815 & 1.464 .211 & 7,62 \\
1981 & 19.761 .054 & 1.170 .465 & 6,43 \\
1982 & 20.057 .468 & 1.178 .472 & 5,88 \\
1983 & 20.258 .045 & 1.003 .115 & 4,95 \\
1984 & 20.260 .438 & 961.575 & 4,75 \\
1985 & 20.452 .109 & 1.077 .861 & 5,27 \\
1986 & 22.211 .680 & 1.207 .868 & 5,44 \\
\hline
\end{tabular}

FONTE: FUNDACENTRO. Bol. Estatístico, São Paulo. 13:48-56, 1987.

É importante que as informações apresentada sobre os acidentes possam ser explicitadas, demonstrando quais acidentes foram atendidos apenas por assistência médica e quais geraram, além disso, incapacidade temporária ou permanete. Esses dados estão colocados na Tabela 7 que refere o número de acidentes liquidados, isto é, queles que tiveram processos encerrados administrativamente, depois de completado 0 tratamento $\mathrm{e}$ indenizadas as sequelas (1). 
Tabela 7 - Distribuição do total de acidentes de trabalho liquidados na área urbana, segundo a classificação, no período de 1980 a 1987, no Brasil.

\begin{tabular}{llllllll}
\hline \multicolumn{7}{c}{ Número de acidentes } \\
\hline Anos & $\begin{array}{l}\text { Assist. } \\
\text { médica }\end{array}$ & \multicolumn{2}{c}{$\begin{array}{c}\text { Incapacidade } \\
\text { temporária }\end{array}$} & $\begin{array}{l}\text { Incap. } \\
\text { perm. }\end{array}$ & Óbitos Total \\
\multicolumn{7}{c}{$\mathbf{- 1 5 d i a s}$} & $+\mathbf{1 5 d i a s}$ \\
\hline 1980 & 207.371 & 791.504 & 473.964 & 27.925 & 4.824 & 1.505 .588 \\
1981 & 166.613 & 679.581 & 428.612 & 29.921 & 4.808 & 1.309 .535 \\
1982 & 140.123 & 635.316 & 407.171 & 31.816 & 4.496 & 1.218 .922 \\
1983 & 124.134 & 527.825 & 364.138 & 30.179 & 4.214 & 1.050 .490 \\
1984 & 131.179 & 492.742 & 352.459 & 28.628 & 4.508 & 1.009 .516 \\
1985 & 153.209 & 528.537 & 378.296 & 27.281 & 4.384 & 1.091 .707 \\
1986 & 164.033 & 585.350 & 414.930 & 24.190 & 4.680 & 1.193 .183 \\
1987 & 170.613 & 571.976 & 403.873 & 23.150 & 5.238 & 1.174 .850 \\
\hline
\end{tabular}

FONTE: ACIDENTES do trabalho. Prev Dados

R. Janeiro, 3 (4) : 27-38, 1988

Podemos observar que, em 1987, a maior parte dos acidentes são de curta duração (49,8\%), enquanto que os de mais de 15 dias também apresentam dados significativos (34,5\%).

Entre 1980 e 1981 observa-se uma redução no percentual de acidentes que geraram incapacidades temporária, mas um aumento daqueles que produziram incapacidade permanente, o mesmo ocorrendo entre 1981 e 1982 . Entre 1983 e 1984 percebe-se uma diminuição do percentual geral, e da incapacidade temporária e permanete e um aumento no número de óbitos. Isto sugere que a subnotificação é real, pois torna-se mais difícil deixar de registrar os casos que levam a óbito.

Entre 1985 e 1986 crescem os acidentes que geram incapacidades temporárias e também o número de óbitos, o que pode demonstrar que vem existindo uma tendência a acidentes de maior gravidade, mesmo que os percentuais gerais tenham diminuído. Em 
1987, ocorreram 5.238 óbitos por acidentes de trabalho o que significa em torno de 14 obitos por dia.

O próprio Ministério da Previdência e Assitência Social através de suas publicações reitera que "no período de 1980 a 1987 os maiores níveis de crescimento são verificados para os acidentes que geraram incapacidade permanente"(1).

Quando os trabalhadores ficam incapacitados permanetemente a Previdência Social realiza a concessão dos seguintes benefícios: auxílio suplementar, auxílio acidentário e aposentadoria por invalidez.

Cabe esclarecer que auxílio suplementar é aquele recebido pelo trabalhador acidentado que teve redução de sua capacidade funcional, sem estar impedido de desenvolver a atividade profissional anterior ao acidente. O auxílio acidentário é aquele recebido pelo trabalhados acidentado que está impossibilitado de desempenhar a atividade profissional anterior, mas não o está para alguma outra que possa vir a desenvolver (1).

A tabela 8 demonstra que, entre os benefícios urbanos, o de

Tabela 8 - Total de benefícios por acidente de trabalho em cadastro, por espécie e clientela em 31/12/87.

\begin{tabular}{lrrrr}
\hline Benefícios & Quantidade & $\%$ & $\%$ Total & Valor médio (*) \\
\hline 1 - Aposent. & 56.982 & 15,1 & 14,8 & 1,27 \\
por invalidez & 84.377 & 22,3 & 21,9 & 1,34 \\
2 - Pensão & 143.074 & 37,9 & 37,2 & 0,52 \\
3 - Aux. Acid. & 93.322 & 24,7 & 24,3 & 0,25 \\
4 - Aux. Supl. & 377.755 & 100 & 98,2 & 0,75 \\
\hline Benef. Urbanos & 4.672 & 66,3 & 1,2 & 0,47 \\
\hline 1 - Aposent. & & & & 0,6 \\
Invalidez & 2.380 & 33,7 & 0,6 & 0,47 \\
2 - Pensão & 7.052 & 100 & 1,8 & 0,47 \\
\hline Benef. Rurais & 384.807 & & 100 & 0,74 \\
\hline Total &
\end{tabular}

FONTE: ACIDENTES do trabalho. Prev Dados, R. Janeiro, $3(4): 27$ - 38, 1988.

(*) Valor médio em número de pisos salariais de dezembro de 1987. 
maior incidência é o auxílio acidentário $(37,9 \%)$ e, entre os rurais, o maior é a aposentadoria por invalidez (66,3\%).

Ainda segundo os dados da Tabel 8, pode-se inferir que a condição de vida do indivíduo que se acidentou e recebe o auxílio acidentário $(0,54 \%$ do piso salarial) está bastante prejudicada, pois recebe um auxílio que inviabiliza uma vida digna e, com certeza, terá sérias dificuldades para sua reinserção em um mercado de trabalho que dispões de extenso exército de reserva.

Do contato com a equipe técnica do Centro de Reabilitação Profissional do Instituto Nacional de Previdência Social, durante pesquisa de campo por mim realizada em 1988, pode-se observar que os próprios técnicos, responsáveis pela reabilitação profissional, referem que é flagrante a dificuldade de reinserção no trabalho, principalmente quando em função diferente daquela exercida no momento do acidente. Referem, ainda, que os próprios trabalhadores desejam ser aposentados por invalidez, pois na realidade estão inválidos para o trabalho formal, isto é, têm dificuldades para obter empregos e acabam por dedicar-se a atividades no mercado informal de trabalho, que, inclusive, não tem o mesmo reconhecimento social.

$\mathrm{Na}$ Tabela 9, que demonstra a distribuição dos acidentes segundo a consequência, no Estado de São Paulo, pode-se observar que é sempre crescente o número de concessões de auxílio suplementar,com esceção do período de 1985 e 1986, enquanto que a concessão de auxílio-acidentário foi crescente entre 1978 e 1979, 1980 e 1981 e 1982 e 1983, sendo acompanhada pela aposentadoria por invalidez. Entre 1984 e 1986, observa-se uma queda no número de concessões de auxílio, tanto suplementar 
quanto acidentário e por invalidez, e um acréscimo de acidentes que levam à simples assistência médica e incapacidade temporária, acompanhando o aumento do número de acidentes.

Tabela 9 - Acidentes liquidados segundo a consequência simples assistência médica, incapacidade temporária, permanente e óbitos no Estado de São Paulo, no período de 1978 e 1986.

\begin{tabular}{|c|c|c|c|c|c|c|c|c|}
\hline \multirow[b]{2}{*}{ Ano } & \multicolumn{3}{|c|}{ Incapac. Tempor. } & \multicolumn{2}{|c|}{ Incapacidade } & \multicolumn{2}{|c|}{ Permanente } & \multirow[b]{2}{*}{$\begin{array}{l}\text { Total acid } \\
\text { líquid. }\end{array}$} \\
\hline & $\begin{array}{l}\text { Assist. } \\
\text { médica }\end{array}$ & $\begin{array}{l}\text { até } 15 \\
\text { dias }\end{array}$ & +15dias & $\begin{array}{l}\text { Aux. } \\
\text { suplem. }\end{array}$ & $\begin{array}{l}\text { Aux. } \\
\text { acid. }\end{array}$ & $\begin{array}{l}\text { Após. } \\
\text { inval. }\end{array}$ & Óbitos & \\
\hline 1978 & 128.014 & 302.920 & 225.308 & 1.699 & 5.038 & 1.184 & 1.119 & 666.186 \\
\hline 1979 & 113.184 & 316.190 & 207.773 & 1.848 & 6.269 & 1.647 & 1.275 & 648.562 \\
\hline 1980 & 126.143 & 339.216 & 198.827 & 2.293 & 5.322 & 1.531 & 1.231 & 674.563 \\
\hline 1981 & 101.782 & 290.087 & 167.971 & 2.410 & 5.595 & 1.923 & 1.261 & 571.029 \\
\hline 1982 & 82.019 & 279.654 & 162.781 & 3.000 & 4.983 & 1.993 & 1.218 & 535.648 \\
\hline 1983 & 71.309 & 238.955 & 146.784 & 4.209 & 4.990 & 1.907 & 1.096 & 468.250 \\
\hline 1984 & 82.608 & 234.232 & 147.901 & 4.382 & 4.883 & 1.801 & 1.164 & 473.971 \\
\hline 1985 & 86.798 & 237.976 & 167.408 & - & $9.429 *$ & * $\quad-$ & 1.234 & 502.845 \\
\hline 1986 & 89.383 & 261.403 & 176.106 & 3.626 & 3.586 & 1.114 & 1.330 & 536.548 \\
\hline
\end{tabular}

Fonte: FUNDACENTRO. Bol. Estatístico, SP 13:48-56, 1987.

* para esse ano, quanto à incapacidade permanete admitiu-se que o número de ocorrências fosse equivalente ao de banafícios concedidos no ano

O aumento do número de óbitos é flagrante entre 1978 e 1979 e entre 1983 e 1986, significando, provavelmente, uma subnotificação e aumento da gravidade dos acidentes, conforme já foi colocado.

Não são apresentados os índices relativos às doenças do trabalho, pois, no Brasil, apenas um número pequeno de doenças são consideradas ligadas ao trabalho. Isso leva à pequena notificação de doenças profissionais, que acabam sendo computadas 
nos dados gerais de morbidade da população, não se estabelecendo o nexo causal com a atividade profissional. POSSAS (27) refere que "anualmente cerca de 3.000 substâncias são introduzidas na indústria. Nos EUA, onde a aplicação da legislação é mais rigorosa que no Brasil, existem normas de exposição permissível para menos de 500 substâncias tóxicas de uso corrente...”(...) “ no caso brasileiro a norma regulamentadora 15 do Ministério do Trabalho estabelece limites de tolerância para somente 200 substâncias". Isso revela a gravidade da condição de trabalho a que estão submetidos grande parte dos trabalhadores.

Os dados colocados, sobre acidentes de trabalho pretendem compor - juntamente com aqueles relativos à incidência e prevalência de incapacidade - o quadro geral das condições de saúde da população, de modo a oferecer a base para o entendimento das estimativas da população portadora de deficiência ou de incapacidade no país, de acordo com as estimativas dos organismos internacionais de saúde.

Compreender as razões da quase inexistência de serviços de saúde que prestam assistência às pessoas portadoras de deficiência, é procurar desvendar uma das faces de sua problemática, que tem estreita relação com outros aspectos da vida, como a educação e o lazer. 
III - OBJETIVOS 


\section{1 - Geral}

Estudar a inserção da atenção à saúde da pessoa portadora de deficiência no sistema de saúde, no Município de São Paulo.

\section{2 - Específicos}

2.1 Caracterizar as propostas de atenção à saúde da pessoa portadora de deficiência no contexto da atual política de saúde. 2.2 Caracterizar, em especial, a proposta do sistema de atendimento à saúde e reabilitação das pessoas portadoras de deficiência da Secretaria do Estado da Saúde de São Paulo.

2.3 Contribuir para a avaliação das propostas de atenção à saúde da pessoa portadora de deficiência frente à necessidade de atenção dessa parcela da população.

2.4 Contribuir para a elaboração de propostas de treinamento e preparação de profissionais envolvidos no desenvolvimento das ações de saúde junto a essa população.

2.5 Sugerir estratégia para a inserção da atenção à pessoa portadora de deficiência na implantação do Sistema Único de Saúde 
IV - UNIVERSO, METODOLOGIA E PROCEDIMENTO 


\section{1 - Universo}

O universo desta monografia é constituído das políticas e propostas de atenção à saúde da pessoa portadora de deficiência e da já existente rede de atendimento de saúde a essa população, tanto pública quanto privada, no Município de São Paulo.

\section{2 - Metodologia e Procedimentos}

Foram utilizadas duas fontes de dados:

1 - a pesquisa documental para contextualizar no desenvolvimento da política de saúde, os aspectos relativos aos serviços de atenção à pessoa portadora de deficiência.

2 - as entrevistas estruturadas com profissionais que trabalham na organização e desenvolvimento de ações de saúde junto à população portadora de deficiência nas diferentes esferas de prestação de serviços: federal, estadual, municipal e privada de caráter filantrópico.

A escolha das instiuições e o consequente número de entrevistas teve por pano de fundo referencial retratar um universo onde se priorizasse a instiuição com uma proposta de criação de sistema de atendimento à saúde daquela população, segundo os princípios básicos do sistema único de saúde apontados no texto constitucional.

A instiuição que apresenta essas características é a Secretaria do Estado de Saúde, que tem elaborado essa proposta desde 1984, e que será melhor detalhada no decorrer deste trabalho.

Assim, foram realizadas 51 entrevistas (Tabela 10) seguindo roteiros diferentes por instiuição e/ou situação funcional, conforme modelos em anexo. Foram gravadas 36 entrevistas e as 
demais não o foram por opção dos entrevistados. As entrevistas tiveram duração média de 45 minutos sendo transcritas para posterior análise de suas informações. Essas entrevistas foram distribuidas da seguinte forma:

Tabela 10 - Entrevistas realizadas segundo tipo de instituição e roteiro de entrevistas.

\section{Instituição}

Roteiro no № de entrev.

\section{Estadual}

1-Gepro * Saúde da Pessoa Deficiente

$1 \quad 5$

2-Gepro * de Problemática Afins

5

6

3-Membro da Direção Regional-SUDS

4-Coordenador do Programa na Região

24

5-Membro da Direção da UBS ${ }^{* *}$ onde

3

4

24

se desenvolve o programa

6-Profissionais que Atendem a Clientela

7-Membro da Direção da Divisão de

4

14

Reabilitação Profissional Vergueiro

6

1 do HC da Faculdade de Med. USP

Total 38

Federal

1-Membro da Direção do Centro de Reabilitação Profissional do INPS - SP

2-Profissional da Equipe de Posto de Assistência Médica

$6 \quad 1$

62

\begin{tabular}{lll}
\hline Municipal & Total & 3 \\
\hline 1-Membro de Assessoria Técnica & & \\
2-Membro da Dir. de Hospital Geral & 6 & 1 \\
3-Coord. Do Atend. Em Hospital Geral & 6 & 1 \\
\hline & Total & 3 \\
\hline
\end{tabular}

\section{Privada}

1-Represent. De Instituição que atende 6 2 à pessoa com incapacidade física

2-Represent. De Instituição que atende

6

3

à pessoa com deficiência mental

3-Deficiência visual

4-Disturbio de Comunicação

$\begin{array}{cc}6 & 1 \\ 6 & 1 \\ \text { Total } & 7\end{array}$

* GEPRO - Grupo especial de Programas, criados em 1986 como assessorai técnica ligada ao CADAIS Centro de Apoio às Ações Integradas de Saúde, que assessora, diretamente, o Secretário de Saúde. 
O número tão extenso de entrevistas com representantes da instituição estadual é devido ao fato de se tentar caracterizar, em especial, essa proposta de atendimento. No desenvolvimento das entrevistas houve necessidade de ampliar seu número, principalmente no Gepro Saúde da Pessoa Deficiente de 02 para 05 entrevistas e entre os profissionais que prestam atendimento direto à clientela de 05 para 14, pois as pessoas referiam não dispor de informações suficientes que pudessem retratar o trabalho que era realizado. Ao mesmo tempo, o número de regiões de saúde, de coordenadores do programa e de unidades de saúde que desenvolvem ações de saúde junto a essa clientela era maior do que o previsto anteriormente.

As entrevistas realizadas com representantes dos serviços ligados ao INAMPS foram diferenciados daquelas da esfera estadual, pelo fato de ainda apresentarem uma dinâmica de trabalho própria, apesar de já fazerem parte da regionalização proposta pelo SUDS *, sendo cada um deles referência para algumas regiões. O serviço do Centro de Reabilitação Profissional do INPS é o únco que se mantém ligado realmente à esfera federal, onde permanece como serviço ligado à Previdência Social.

* SUDS - Sistema Unificado e Descentralizado de Saúde, que tem por responsabilidade propor, coordenar e organizar as ações de saúde naquela determinada área geográfica. No município de São Paulo, em agosto de 1989, existiam os seguintes SUDS:

$\begin{array}{ll}1 \text { - Sé } & 5 \text { - Itaquera } \\ 2 \text { - Lapa } & 6 \text { - Mandaqui } \\ 3 \text { - Vila Prudente } & 7 \text { - Freguesia do O } \\ 4 \text { - Penha } & 8 \text {-Santo Amaro }\end{array}$


As entrevistas realizadas com representantes dos serviços privados buscaram retratar diferentes entidades que atendem a parcelas diferenciadas de pessoas portadoras de deficiência. As entidades foram recolhidas por representarem aquelas que, tradicionalmente, atendem essa clientela. Apesar de ser serviço ligado à instiuição estadual para a DRPV - Divisão de Reabilitação Profissional Vergueiro, ligada do Hospital de Clínicas (que é hospital-escola) foi utilizado o mesmo roteiro das demais instiuições privadas, porque a mesma funciona mais com essa característica.

Os entrevistados foram apontados como representantes de seus serviços e instituições pelos próprios serviços, a não ser nos casos em que representavam o grupo como um todo, tal como no Gepro * da Saúde da Pessoa Deficiente, Diretores de SUDS, Coordenadores do Programa ou Coordenadores de outros Gepros afins.

Todas as entrevistas tiveram como base roteiro com perguntas abertas para que fosse possível o aparecimento de diferentes enfoques e prioridades, segundo a intenção das pessoas entrevistadas.

A análise das entrevistas foi feita a partir de inferência qualitativa. Inicialmente foram levantados os principais aspectos de cada uma e posteriormete fez-se seu agrupamento segundo as

* Essa era a denominação utilizada até fevereiro de 1990 para os grupos especiais de programas. A partir de fevereiro de 1990 houve alteração no trabalho desenvolvido na Secretaria de Estado. Foram formadas cinco grandes áreas de ação: saúde da criança, saúde da mulher, saúde do adulto, saúde mental e saúde bucal. Os antigos Gepros afins com essas áreas foram incorporados a elas e outros permaneceram como programas especiais como é o caso do Gepro Saúde da Pessoa Deficiente. Neste trabalho será mantida essa denominação porque era a utilizada no interior dos serviços. 
instituições priorizadas e os seus subgrupos, tendo como referência as perguntas colocadas.

Optou-se pela apresentação até exaustiva das entrevistas, como forma de registras essas informações, para que outros profissionais também possam avaliar os resultados.

Num segundo momento analisamos de maneira mais geral as entrevistas, caracterizando os diferentes aspectos das reflexões colocadas e tentando integrá-las às questões gerais do delineamento das propostas de atenção à clientela e da caracterização de cidadania por elas revelada.

A sequência escolhida para a apresentação dos resultados das entrevistas, está explicitada no capítulo VI.

No decorrer do trabalho ocorrem mudanças da legislação, algumas extremamente importantes tais como a regulamentação deo S.U.S. a elaboração da(s) lei(s) orgânica(s) do(s) município(s). Assim, podem ocorrer eventuais afirmações não atualizadas quanto à subordinação de orgãos e aspectos semelhantes. É o caso, por exemplo, da citação concomitante do SUDS e do SUS. 
V - CIDADANIA, POLÍTICAS SOCIAIS

E O DESENVOLVIMENTO DOS

SERVIÇOS DE ATENÇÃO À SAÚDE

DA PESSOA DEFICIENTE 


\section{1 - A questão da cidadania e as políticas sociais}

A atenção à saúde das pessoas incapacitadas é um problema complexo, cuja solução depende da estruturação de serviços de atenção à saúde para a população em geral, e não exclusivamente para essa população, bem como de todas as outras ações que estão implícitas no conceito amplo de saúde.

Sabe-se, conforme já exposto no capítulo II, que se conta com um número insuficiente de serviços que atendam à pessoa deficiente, os quais em sua quase totalidade encontram-se na iniciativa privada de caráter beneficente e filantrópico. Essas instituições, em sua grande maioria, desenvolvem serviços em que se empregam procedimentos de alto custo e abrangência, conforme depoimentos colhidos nas entrevistas.

Segundo já exposto anteriormente, essa população também se encontra excluída, inclusive, do próprio processo de produção da riqueza, apesar de ser frutos dele. Não se constitui sequer como exército de reserva, o que dificulta, ainda mais, o seu processo de inserção social, propugnado pelos organismos internacionais como objetivo final do tratamento de reabilitação.

O número insuficiente de serviços de atenção à saúde da pessoa portadora de deficiência guarda, a meu ver, estreita relação com a formulação e desenvolvimento das políticas sociais, tanto as de assistência social quanto as de saúde.

Pode-se compreender o estabelecimento das políticas sociais através das medidas de proteção social implementadas pelo Estado a partir da discussão do que seja a concepção de cidadania e de como esta se desenvolve nos diferentes períodos histórico. Trabalhar com o conceito de cidadania é resgatar, a condição em 
que se encontram os atores sociais, é analisar a relação entre cidadão e o Estado, que se estabelece sobre um série de direitos, os direitos sociais.

É através das políticas sociais que se tornam manifestas as medidas de proteção social.

No processo de desenvolvimento da sociedade capitalista observam-se diferentes perfis de saúde e doença conforme a inserção de seus indivíduos no processo de produção (22).

Essa questão pode ficar melhor explicitamente observando-se alguns indicadores, como por exemplo, a concentração de renda: em 1986 os $10 \%$ mais ricos se apropriam de $46,2 \%$ da renda total e os $50 \%$ mais pobres de $13,6 \%$. Enquanto a PNAD 84 revelou que " $52,6 \%$ das famílias brasileiras encontram-se na linha da pobreza ( até 02 salários mínimos) sendo que $28,3 \%$ recebem de zero a 01 salário mínimo e $\mathbf{2 4 , 3} \%$ de um a dois salários mínimos, o que também ocorre em 61,2\% da População Economicamente Ativa. Cabe mencionar, ainda, que 68 milhões de brasileiros vivem em famílias com renda inferior a três salários mínimos e 18 milhões de trabalhadores recebem menos de um salário mínimo" (36).

Outros dados alarmantes são relativos ao déficit alimentar. Embora o problema permaneça atual, dados de 1975 demonstram que a desnutrição da população até 18 anos era de ordem de 58\% (36).

Conforme TEIXEIRA (36), esses dados refletem a dimensão das necessidades sociais de nossa população, apesar de não deixar tão explícitas as características da pobreza, faltando-nos informações sobre como se articulam demandas sociais e necessidades.

Com esse perfil de necessidades sociais entendem-se, em 
parte, os percentuais de incidência e prevalência de incapacidade ou deficiência entre a população de países do Terceiro Mundo esperados pelos orgãos internacionais de Saúde.

No Brasil, com um modelo de desenvolvimento extremamente concentrador de renda, a reposição das energias consumidas pelos trabalhadores no processo de produção pode se dar, parcialmente, através de acesso a bens e serviços como saúde, educação, transporte, habitação, lazes, entre outros. No entanto, os baixos salários já descritos impossibilitam esse acesso.

Isto significa que o Estado, através das políticas sociais, será responsável pelo desenvolvimento de medidas de proteção social em saúde, habitação, transporte, educação como forma de dar à população acesso a esses bens e serviços e garantir a manutenção e reprodução da força de trabalho.

As políticas sociais são historicamente determinadas e, no entender de TEIXEIRA (36), tendem a expressar-se através daquilo que se pode denominar por assistência social, seguro social e seguridade social.

Aqui tentar-se-à traçar um paralelo entre a concepção dessas formas de proteção social e algumas medidas importantes estabelecidas no âmbito do atendimento à saúde das pessoas portadoras de deficiência.

$\mathrm{Na}$ primeira forma, a assistência social, existe 0 reconhecimento de necessidades dos indivíduos e a consequente proposição de seu atendimento. É onde os cidadãos serão as familias carentes, os menores abandonados, os idosos desamparados, os deficientes, entre outros. Todos devem provar através de atestados de pobreza, de saúde ou de pequena renda 
familiar a sua própria miséria e sofrimento. Assim, a autora considera que se cria uma relação denominada de cidadania invertida, onde o indivíduo é beneficiário pelo fato de não conseguir exercer a condição de cidadão. Sua relação com o Estado se inicia quando se reconhece como não - cidadão. Essa concepção norteou a criação de proposta de atenção, tanto do Estado quanto da sociedade civil, às pessoas portadoras de deficiência e incapacidades. Essas propostas foram desenvolvidas diretamente pelo Estado no atendimento aos doentes mentais e psicopatas e pela sociedade civil no atendimento dos deficientes físicos e mentais. SPOSATTI et al (25) referem que "a primeira instituição de assistência social será a LBA - Legião Brasileira de Estado em 1942. Organismo que assegura estatutariamente sua presidência às primeiras - damas da República. Representa a simbiose entre a iniciativa privada e a pública, a presença da classe dominante enquanto poder civil e a relação benefício / caridade - beneficiário / pedinte, conformando a relação básica entre Estado e classes subalternas".

É também a partir da década de 40 que, conforme relata SOARES (34), foram criadas "instituições filantrópicas - sem fins lucrativso - e particulares por iniciativa da sociedade civil."... “O atendimento aos deficientes foi divulgado pelo Rotary Internacional que patrocinou a criação da Sociedade Internacional de Crianças Lesadas (1919) e da Sociedade Internacional para o Bem-Estar dos Lesados (1922). Estas se encarregaram de organizar congressos, cursos e cultivar a opinião pública favorável aos programas de intervenção". 
Outra instiuição responsável por consolidar medidas de proteção social à infância, foi a FUNABEM - Fundação Nacional do Bem Estar do Menor, criada em 1964. No entanto desde 1893 houve diferentes iniciativas relacionadas à assistência ao menor, que foram reformuladas e repropostas até a criação da FUNABEM (36).

Inicialmente a LBA tinha como prioridade a defesa da maternidade e da infância, mas houve alterações em seus estatutos em 1966 e em 1979, onde se tentou adequar essa instiuição às mudanças que ocorreram após a unificação dos diferentes institutos de aposentadorias e pensões pela Lei Orgânica da Previdência Social, e após a criação do SINPAS - Sistema Nacional de Previdência e Assistência Social em 1977 (36).

Assim, LBA e FUNABEM passam também a integrar o SINPAS e estre os diferentes programas dessas duas instituições estão programas de atenção às pessoas portadoras de deficiência.

A regulamentação mais recente sobre a prestação de assistência às pessoas portadoras de deficiência proposta pelo Ministério da Previdência e Assistência Social é datada de 27 de março de 1987, pela Ação Normativa SAS no 01/87 onde se propõe a assitência prestada pela LBA e pela FUNABEM (18). Nessa norma está prevista assistência através do desenvolvimento de ações em programas preventivos ou terapêuticos.

A população alvo dessas ações seriam os indivíduos, famílias, grupos e comunidades, assim como grupos específicos como gestantes e bebês de alto risco, pessoas portadoras de deficiências que se beneficiariam de tratamento de habilitação/reabilitação, menores (órfãos, abandonados, infratores) portadores de deficiência. Esse atendimento seria 
desenvolvido diretamente por meio de encaminhamento às entidades conveniadas ou contratadas, do acompanhamento da programação terapêutica com objetivo de sua conclusão, acompanhamento de programas e projetos específicos ou ainda da adoção de medidas que garantam padrão de qualidade no atendimento como reavaliação, supervisão, assessoria técnica, treinamento e reciclagem de pessoal próprio ou de recursos humanos na comunidade. $\mathrm{O}$ atendimento indireto seria por meio de convênio ou contrato com entidades especializadas públicas ou privadas através do pagamento de bolsas per capita, isto é por pessoa atendida.

Segundo a própria LBA, em agosto de 1989 o valor dessas bolsas variava de 8,0 BTN para bolsas de manutenção até 91,4 BTN para tratamento precoce. Nesse período havia 245 entidades conveniadas que atendiam 108.248 clientes no Estado de São Paulo.

Ainda nessa perspectiva do desenvolvimento de assistência à pessoa portadora de deficiência, o Fundo Social de Solidariedade ligada ao Governo do Estado de São Paulo, também sob a presidência da primeira - dama do Estado, tem acompanhado alguns projetos de trabalho junto a essa população. Estes vêm sendo desenvolvidos em 168 municípios também sob a responsabilidade da primeira - dama de cada uma dessas cidades. Atualmente, tem-se trabalhado com ações preventivas da saúde visual junto aos alunos de pré-escola, $1^{\underline{a}}$ e $2^{\underline{a}}$ séries das escolas municipais e estaduais. $O$ professor aplica testes de visão e encaminha ao médico especialista aqueles alunos que apresentarem problemas. Quando necessário o Fundo Social de Solidariedade faz o financiamento dos óculos. Até 30 de dezembro de 1989, haviam sido tratadas 
1.175.103 crianças, sendo que 121.111 passaram por consulta médica, 61.265 tiveram seus óculos financiados e 1.998 foram encaminhados a cirurgia ou concessão de lentes especiais. Segundo dados colhidos em entrevista com profissional ligado ao Fundo, essa seria uma das ações junto à população portadora de deficiência.

O Fundo Social de Solidariedade ainda tem a perspectiva de em 1990 dar início a um projeto de treinamento e profissionalização de pessoas deficientes, a partir dos 14 anos, recém-saídos das classes especiais ou de instituições especializadas. $O$ trabalho será realizado em conjunto com a LBA de São Paulo que investirá NCz\$93 milhões de cruzados novos nesse projeto de profissionalização de deficientes físicos. $O$ objetivo do projeto é permitir aos deficientes criarem suas próprias micro empresas.A LBA também firmou outro convênio com a FOS - Federação de Obras Sociais, que congrega três mil entidades de cunho social, e que recebeu NCz\$218 milhões de cruzados para investimento na montagem de 200 microempresas sociais (19). No entanto a data de estabelecimento do convênio LBA - Fundo Social de Solidariedade é dezembro de 1988 e a previsão para início do trabalho é em 1990, a morosidade para início desse trabalho é explicada pela necessidade de reformas no prédio sede do projeto.

Assim, as entidades particulares e filantrópicas vão se expandindo à medida em que os orgãos governamentais como a LBA e a FUNABEM passa a the fornecer subsídios pelos serviços prestados em saúde e/ou educação especial, seja ao menor, seja ao deficiente físico, mental ou sensorial, bem como ao idoso. É a 
tradução concreta das iniciativas que trazem e reforçam a concepção da cidadania invertida.

A segunda forma de entender a questão da cidadania, ainda segundo TEIXEIRA, passa a se dar a partir do reconhecimento dos trabalhadores como atores sociais. Aqui se fala de cidadania regular onde, através da constribuição dos assalariados, se cria o seguro social. Nesse seguro os benefícios são proporcionais à contribuição recolhida e não às necessidades. Como a organização e funcionamento dos serviços dessa natureza dependem da contribuição dos trabalhadores e não existe qualquer outra forma de subsídio, seja orçamentária seja de outro tipo, perpetuam-se as desigualdades que se estabelecem na organização da forma de produção. Assim, da década de 40 até início de 60, as categorias profissionais mais organizadas e que detinham maior renda tinham seus Institutos de Previdência em condições de oferecer melhor qualidade nos atendimentos prestados, como entre os industriários e bancários. Isso trouxe reflexos na atenção à saúde da pessoa deficiente, pois passaram a ser atendidos também aqueles indivíduos desgastados pelo processo de trabalho que adoeceram ou sofreram acidentes de trabalho. Esta seria uma forma de garantir, via serviços de saúde, a manutenção e reprodução da força de trabalho que prioriza aqueles que tenham vínculo empregatício, que participam, diretamente, da produção da riqueza. No entanto, o atendimento das pessoas deficientes, que não estavam inseridas na produção, continua sendo desevolvido, prioritariamente, pelas instituições de assistência social quer privadas, quer filantrópicas, ou por alguns poucos serviços públicos ligados às Universidades, como no Hospital das Clínicas da Faculdade de 
Medicina da USP, através do Instituto de Reabilitação desde 1956 e, posteriormente, da Divisão de Reabilitação Profissional Vergueiro desde 1975.

Após a Lei Orgânica da Previdência Social e a unificação dos institutos de aposentadoria e pensões das diferentes categorias profissionais no Instituto Nacional de Previdência Social (INPS) ocorre um crescimento dos serviços de reabilitação, que são incorporados aos hospitais gerais privados e conveniados com a Previdência Social através de serviços de fisioterapia. Esses serviços conforme SOARES (34) priorizavam e ainda priorizam o atendimento de indivíduos que apresentem sintomas biológicos mais comuns como dores, perda da capacidade respiratória ou da mobilidade advindos do processo de trabalho. Assim se amplia a parcela da população atendida através dessa unificação.

É também da década de 70 a formação dos Centros de Reabilitação Profissional do INPS para seus segurados, sendo o primeiro na cidade de São Paulo e, posteriormente, em Campinas, Santos e Bauru. Ainda hoje, o Centro de São Paulo é o que atende ao maior número de segurados no Estado e no país.

O Ministério da Previdência e Assitência Social através da Secretaria de Previdência Social divulgou portaria de ํo 07 de maio de 1987 onde dispunha sobre a reabilitação profissional “ como a assistência de readaptação profissional que visa proporcionar aos beneficiários da previdência social, quando doentes, inválidos ou de algum modo físico ou mentalmente deficientes, independentemente de período de carência, com a amplitude que as possibilidades administrativas, técnicas e financeiras e as condições locais permitirem, os meio de 
reeducação ou readaptação profissional indicados para que possam retornar à atividade laborativa" (24). Nessa portaria todos têm direito à reabilitação profissional, preferencialmente os segurados acidentados do trabalho ou em gozo de benefício por incapacidade. Ao mesmo tempo essa portaria detalha obrigatoriedade de que as empresas com 20 ou mais empregados, reservam de $2 \%$ a $5 \%$ dos seus cargos para receber os casos de beneficiários reabilitados onde:

$\begin{array}{ll}\text { "até } 200 \text { empregados } & 2 \% \\ \text { de } 201 \text { a } 500 & 3 \% \\ \text { de } 501 \text { a } 1.000 & 4 \% \\ \text { de } 1.000 \text { em diante } & 5 \% "(24)\end{array}$

No entanto, os depoimentos de profissionais do próprio Centro de Reabilitação do INPS de São Paulo referem que existe grande dificuldade de fixação, no mercado de trabalho dos segurados que passaram por reabilitação profissional, dada a extensa massa de trabalhadores que compões o exército de reserva.

Assim, a iniciativa de assistência pública em reabilitação profissional, que é das poucas que o setor público oferece diretamente à pessoa portadora de deficiência, isto é, com recursos próprios, não dependendo de convênio está restrita apenas aos segurados, não é extensiva aos seus dependentes. Isto vem ilustrar o que se chamou cidadania regular.

$\mathrm{Na}$ concepção de cidadania plena caberia ao Estado gerir os recursos socias no sentido de consolidar a seguridade social, que se baseia no fato de que existem direitos sociais inerentes à condição de cidadania que devem ser garantidos e onde é necessário maior distribuição de renda e de justiça social para que se possa exercer esses direitos e não apenas políticas 
sociais voltadas para o bem estar daqueles que não têm acesso a salários e condições de vida dignos. Esta concepção se diferencia das demais que se baseavam na demonstração da necessidade ou na existência de um contrato de trabalho regido pelas normas trabalhistas.

A conquista da cidadania plena se dá num processo, processo este de luta da sociedade civil para conquista de direitos políticos e sociais. Assim, as pessoas portadoras de deficiência também participaram desse processo da sociedade civil na luta por seus direitos. Na década de 80 começam a consolidar-se movimentos de defesa da pessoa portadora de deficiência, que congregam os próprios portadores de deficiência, isto é, eles próprios são os interlocutores com o poder público, no sentido de apontar as necessidades e apresentar as duas reinvindicações, como parcela da população marginalizada, sem acesso a direitos mínimos como de transporte, educação e saúde entre outros.

Em 1981 - Ano Internacional da Pessoa Deficiente houve uma série de debates entre essas entidades representantes de pessoas deficientes e o poder público, federal, estadual e municipal, onde se apontou mais uma vez a necessidade de uma diretriz política para a questão da problemática da pessoa portadora de deficiência.

Uma das iniciativas de consolidação dessa diretriz política foi a criação do Conselho Estadual para Assuntos da Pessoa Deficiente pelo Decreto lei no 23.131/84 de 19/12/84. Esse Conselho composto por representantes de instituições prestadoras de serviços para essa população e por representantes de entidade de pessoa portadoras de deficiência tem papel de assessoria do 
governo estadual, tem produzido e reproduzido material didático para divulgação de formas de prevenção, detecção precoce e tratamento de deficiêntes.

Em 1985 pelo Decreto lei municipal no 21.509 de 25 de outubro foi criado o Conselho Municipal da Pessoa Deficiente que de 1986 a 1988 esteve desativado, sendo que em 21 de agosto de 1989 o decreto lei no 28.044 reativa e dá nova constituição ao Conselho que passa a contar com a participação de representantes de entidades e movimentos sociais de pessoas deficientes. Esse Conselho vem trabalhando sobre alguns temas básicos como: transporte, educação e reabilitação, esportes, barreiras arquitetônicas, admissão no serviço público municipal e criação de alternativas aos hospitais de retaguarda (11).

Representando os esforços a nível federal para a integração da pessoa deficiente em 29 de outubro de 1986, foi criada a CORDE Coodenadoria para a Integração da Pessoa Portadora de Deficiência, pelo Decreto lei no 93.481, que nesse período esteve ligada à Secretaria de Planejamento e Coordenação da Previdência da República (6).

A CORDE dispunha de Conselho Consultivo com representantes do antigo MEC - Ministério de Educação e Cultura, representante da LBA, FUNABEM, INAMPS, INPS, Ministério do Trabalho e da Saúde, e de instituições ligadas à prestação de serviços para essa população. Nesse período a CORDE lança um primeiro Plano de Ação composto por quatro programas: programa de conscientização, programa de prevenção de deficiência, programa de atendimento às pessoas portadoras de deficiência no mercado de trabalho. A 
intenção desse plano é de oferecer "uma diretriz politicamente firme e socialmente transformadora que dê unidade e integre as ações de atendimento, previdência e assistência, num só esforço e nele incorpore governo e sociedade no mesmo movimento" (14).

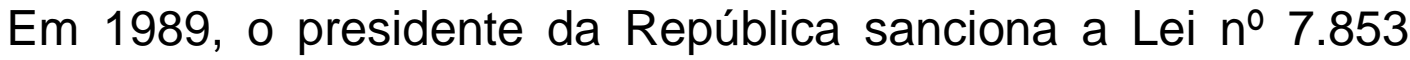
de 24 de outubro que dispõe sobre o apoio às pessoas portadoras de deficiência, e sua integração social como também sobre a CORDE instituindo, também, a tutela jurisdicional de interesses coletivos ou difusos dessas pessoas, disciplinando a atuação do Ministério Público e definindo crimes (19). Essa lei vem sendo divulgada nos meios de comunicação de massa. Nesse texto legal cabe aos orgãos e entidades da administração direta e indireta dispensar tratamento prioritário e adequado para viabilizar medidas na área da educação como por exemplo oferta obrigatória e gratuita da Educação Especial nos estabelecimentos públicos de ensino e a matrícula compulsória em cursos regulares de estabelecimentos públicos e particulares de pessoas portadoras de deficiência capazes de se integrar no sistema regular de ensino. No âmbito da saúde a lei refere-se a necessidade da promoção de ações preventivas de deficiências, de desenvolvimento de programas de prevenção de acidentes, da criação de rede de serviços especializados em reabilitação e habilitação, de garantir a essa população acesso aos serviços de saúde públicos e privados com tratamento adequado. Além de sugerir que os programas de saúde sejam realizados com a participação dessa população.

No âmbito da formação profissional e do trabalho sugere a promoção de ações eficazes para inserção dessa população no setor 
público e privado; o apoio à formação profissional, a adoção de legislação específica para criação de reserva de mercado de trabalho para essas pessoas no setor público e privado entre outras.

Ainda sugere ações para formação de professores e de técnicos de nível médio para habilitação e reabilitação, bem como formação profissional.

Também está referido nessa lei que o Ministério Público, a União, os Estados, os Municípios, as associações de pessoas portadoras de deficiência entre outras instituições, poderão propor ações civis públicas destinadas à proteção de interesses coletivos ou difusos das pessoas portadoras de deficiência.

Também a lei refere em seu artigo 8ํㅜ , que constitui crime punível com reclusão de 01 a 04 anos e multa dificultas, sem justa causa, inscrição de aluno em estabelecimento de ensino público ou privado em razão de sua deficiência; negar emprego ou trabalho; dificultar a prestaçaõ de assistência médica entre outras.

Ainda segundo a lei, será necessária a proposição de Política Nacional para Integraçaõ da Pessoa Portadora de Deficiência junto à Presidência da República, que será função da CORDE, que passará a ser reestruturada como orgão autônomo.

Essa lei representa uma possibilidade para que as próprias entidades representativas dessa parcela da população pressionem os poderes públicos e o setor privado para que esta não se transforme em mais de uma iniciativa vazia. É preciso dela se utilizar para dar corpo, trazes à tona e responsabilizar pessoas ou instituições por qualquer espécie de discriminação sofrida por 
essa população. De qualquer forma, é dispositivo legal que vem novamente referendar o texto constitucional que afirma que todos são iguais perante a lei, sem distinção de qualquer natureza. $O$ texto constitucional também assegura o direito à saúde, educação e a habilitaçãoe reabilitação, bem como à promoção de sua integração à vida comunitária; ao mesmo tempo que propõe um salário mínimo como benefício mensal a essa população e aos idosos que comprovem não possuir meios de prover a própria manutenção, mas depende de lei que o detalhe (3).

Assim, a garantia do exercício desses direitos é questão que deve ser alvo das discussões das organizações de pessoas portadoras de deficiência, ou seja, será resultado da pressão social que se conseguir exercer junto ao poder executivo, legislativo e judiciário federal, municipal e estadual. A luta pela cidadania plena transcende as questões específicas de saúde.

\section{2 - A atenção à saúde como direito da pessoa portadora de deficiência e o Sistema Único de Saúde}

\section{1 - O direito à saúde e o Sistema Único de Saúde}

Este é um momento fundamental para o estabelecimento de um sistema de saúde no Brasil, onde se possa pensar claramente o papel das diferentes instiuições prestadoras de serviços quer públicas, quer privadas, de caráter banaficiente ou não. O texto constitucional federal, apresenta a questão do direito à saúde como direito social, juntamente com os direitos a: educação, o trabalho, o lazer, a segurança, a proteção à maternidade e à infância, a assitência aos desamparados (4).

No título Da Ordem Social da constituição federal e da 
Estadual encontram-se os capítulos relativos à seguridade social onde se circunscreve a questão da sáude. A saúde é considerada direito de todos e dever do Estado que a garantirá, conforme artigo 219 da Constituição Estadual (30), mediante o estabelecimento de políticas sociais, econômicas e ambientais; o acesso universal e igualitário às ações e ao serviço de saúde em todos os níveis; o direito à obtenção de informações sobre saúde individual e coletiva; o atendimento integral da pessoa que engloba promoção, preservação e recuperação de sua saúde.

Segundo as constituições, as ações e os serviços de saúde devem ser executados pelos orgãos públicos federais, estaduais e municipais, constituindo o Sistema Único de Saúde que terá como diretrizes e bases, no Estado de São Paulo:

A descentralização com direção única estadual e municipal, a municipalização dos recursos, serviços e ações de saúde; a integração das ações e serviços com base na regionalização e hierarquização do atendimento, segundo o perfil epidemiológico; a universalização da assistência e a gratuidade dos serviços (30).

Também será competência do SUS a assistência integral à saúde onde se respeite as especifidades dos segmentos da população; a identificação e controle dos fatores determinantes da saúde indivídual e coletiva com ações de: vigilância sanitária e epidemiológica, saúde do trabalhador, idoso, da mulher, da criança e do adolescente e dos portadores de deficiência. Além dos tópicos relativos ao meio ambiente, inclusive o ambiente de trabalho; os componentes famacêuticos, medicamentos e produtos químicos, imunobiológicos entre outros.

Os textos constitucionais ainda trazem questões das pessoas 
Portadoras de deficiência nos temas sobre a assistência social, da constituição federal e sobre a proteção especial na constituição estadual.

No artigo 203 da Constituição Federal se define que a assistência social tem por objetivos:

“I - a proteção à família, à maternidade, à infância, à adolescência e velhice;

II - a amparo às crianças e adolescentes carentes;

III - a promoção da integração ao mercado de trabalho;

IV - a habilitação e reabilitação das pessoas portadoras de deficiência e a promoção de sua integração à vida comunitária;

V - a garantia de um salário mínimo de benefício mensal à pessoa portadora de deficiência e ao idoso que comprovem não possuir meios de prover à propria manutenção ou de tê-la provido por sua família, conforme descreve a lei" (2)

No texto da Constituiçção Estadual em seu Artigo 277 é tarefa do poder público e da família priorizar a criança, o adolescente, o idoso e os portadores de deficiência no direita à vida, à alimentação, à educação, ao lazer, à profissionalidade, à cultura, à dignidade, ao respeito, a liberdade e à convivência familiar e comunitária (29).

Nos artigos 279, 280 e 281, dessa mesma constituição chegase a grande detalhamento:

"Artigo 279 - Os Poderes Públicos estadual e municipal assegurarão condições de prevenção de deficiência, com prioridade para a assistência pré-natal e à infância, bem como integração social de portadores de deficiência, mediante treinamento para o trabalho e para a convivência, mediante:

I - criação de centros profissionalizantes: para treinamento, habilitação e reabilitação profissional de portadores de deficiências, oferecendo os meios adequados para esse fim aos que não tenham condições de frequentar a rede regular de ensino;

II - Implantação de sistema "Braille" em estabelecimento da rede oficial de ensino, em cidade polo regional, de forma a atender às necessidades educacionais e sociais dos portadores de deficiência. 
PARÁGRAFO ÚNICO - As empresas que adaptarem seus equipamentos para o trabalho de portadores de deficiências, poderão receber incentivos na forma de lei:

ARTIGO 280 - É assegurado, na forma da lei, aos portadores de deficiência e aos idosos 0 acesso adequado aos logradouros e edifícios de uso público, bem como aos veículos de transporte coletivo urbano.

ARTIGO 281 - 0 Estado propiciará, por meio de financiamento, aos portadores de deficiências, aquisição dos equipamentos que se destinem a uso pessoal e que permitam a correção, diminuição e superação de suas limitações, segundo condições a serem estabelecidas por lei" (29).

Pode-se perceber, que os textos constitucionais apresentam a pessoa portadora de deficiência como plena de direitos nas mais diversas esferas de sua vida e em situação de semelhança e igualdade às demais pessoas. $O$ fato dos textos se referirem tão diretamente a sua problemática pode revelar, inclusive, o grau de abandono em que se encontram essas pessoas. No estanto, essa referência tão explícita também é fruto das discussões, da organização e da pressão social dessa população sobre a sociedade e sobre as autoridades. Revelam também que as pessoas portadoras de deficiências estão dispostas a lutar pelo exercício de seus direitos e portanto de sua cidadania.

Esse exercício poderá ser ampliado ou cerceado à medida que se estruturam o Sistema Único de Saúde e as medidas de proteção social implementadas por instituições como a LBA e FUNABEM, entre outras que delineiam os caminhos possíveis para a implementação da atenção à essa população. Houve reestruturação ministerial apresentadas ao Congresso Nacional em março de 1990 através da medida provisória número 150 e do Decreto número 99.179. Esta delineia funções e transfere para o Ministério do Trabalho e da Previdência Social as atribuições do Instituto Nacional da 
Previdência Social - INPS, para o Ministério da Saúde as atribuições do Instituto Nacional de Assistência Médica - INAMPS e para o Ministério da Ação Social a Coordenadoria Nacional para Integração da Pessoa Portadora de Deficiência - CORDE e a Fundação Legião Brasileira de Assistência - LBA. Essas mudanças aliadas àquelas de caráter político e econômico mais geral também definirão os rumos a serem tomados no delineamento de todas as políticas, principalmente as de caráter social.

\section{2 - O modelo assistêncial e suas repercussões}

Para se discutir a inserção da atenção à saúde da pessoa portadora de deficiência no Sistema Único de Saúde é importante fazê-lo inclusive, a partir de uma discussão sobre o que seja modelo assistencial e como este se desenvolve.

No entender de CAMPOS (12) "modelo assistencial deveria ser conceituado como o modo como são produzidas as ações de saúde e a maneira como os serviços de saúde e o Estado se organizam para produzí-las e distribuí-las".

O autor aponta a existência de principalmente três modelos assistenciais, consequência de diferentes políticas de saúde e que ainda estão no cotidiano da política atual.

Esses modelos seriam 0 liberal - privatista, 0 racionalizador - reformista e o do sistem único de saúde que ainda está por ser construído. No primeiro modelo, liberal privatista é o mercado que organiza os serviços de saúde e não as necessidades de saúde. Esse modelo traz grande desigualdade de acesso dos consumidores aos serviços de saúde ou seja os de 
maior poder aquisitivo têm serviços altamente especializados, os demais ou seja aqueles para quem o Estado compra serviços têm acesso a apenas uma rede de pronto atendimento onde a atenção é de baixa resolutibilidade e impessoal. Para os dois consumidores se priorizou uma organização de atenção médica centralizada no atendimento individual e curativo. Nesse modelo o papel do Estado foi sempre priorizar e comprar os serviços e prestar atendimento à população que não estava incorporada ao mercado formal de eficácia e de legitimidade; mas tem amplo apoio dos empresários, parte dos profissionais e tamém da população com maior poder aquisitivo.

No segundo modelo, racionalizador - reformista oriundo do interior do próprio Estado tentar-se-ia corrigir as distorções mais gritantes do modelo liberal, mas sem terminar com a medicina de mercado. Assim, surgiram diversos projetos entre eles as Ações Integradas de Saúde que posteriormente teriam melhores condições de consolidação através da criação do SUDS - Sistemas Unificados e Descentralizados de Saúde nos Estados, conforme exposição de motivos para sua criaçãono Decreto lei no 94.657 de 20 de julho de 1987. Este considerava que as "AIS deveriam ser reconceitualizadas numa outra perspectiva qualitativa que transcenda sua proposta como instrumento de racionalização ou de transferência e integração de recursos, mediante convênios entre instituições públicas” (7) Estas AIS passariam a "significar um movimento de reorganização setorial no sentido da Reforma Sanitária que permita caminhar, gradativamente, para

a superação 
da atual organização sanitária, centralizada e desordenada..."(7). Assim o próprio decreto propõe a redefinição das atribuições dos três níveis federativos; federal, estadual e municipal.

As alternativas das AIS e SUDS, segundo CAMPOS (12) terminaram ampliando a capacidade de produzir serviços de saúde do Estado tanto em saúde pública quanto em atenção hospitalar e ambulatorial; e incorporaram o planejamento em saúde como instrumento mais adequado do que a lógica do mercado, ao mesmo tempo que foram uma referência contra o modelo anterior.

Apesar dessa proposta, que amplia o papel do Estado, o autor considera que os princípios da organização liberal dos serviços de saúde acabam se apresentando como os predominantes na própria organização dos serviços públicos. Ou seja, os antigos Centros de Saúde passam a se tornar pronto - atendimento; os hospitais públicos passa a se organizar dentro da mesma lógica privada e continua o financiamento público para os serviços privados. 0 autor ainda aponta que nesse modelo a rede básica de saúde não tem conseguido se desenvolver principalmente porque os recursos "continuam sendo investidos com outras finalidade" (12).

No terceiro modelo que seria o do Sistema Único de Saúde, que está por ser construído, o principal critério para organizá-lo deveria ser o do planejamento em saúde, isto é, a partir das necessidades de saúde da população e não do poder aquisitivo das pessoas. Esta seria, segundo o autor, a maneira de tratar a saúde como direito, onde 0 "atendimento será universal - todos poderiam utilizar o sistema, gratuito e organizado, a partir de uma 
racionalidade técnica e política; hierarquizado segundo a complexidade da atenção e regionalização conforme a distribuição populacional e o quadro de morbimortalidade das comunidades. É claro que essa alternativa é antagônica à medicina de mercado, que poderia existir apenas enquanto prática alternativa custeada diretamente apenas pelos que optassem por tal modalidade de assistência" (12).

O autor aponta que para que esse modelo se consolide é necessário uma ampla rede de unidades básicas de saúde que justamente com os pronto socorros dariam o primeiro atendimento às pessoas. Também sugere que essa rede deveria prover 0 atendimento ambulatorial básico às intercorrência clínicas de todas as faixas etária e, concomitantemente, desenvolver ações de saúde pública. Nessa rede as equipes teriam formação para atenção à criança, mulher e adulto em geral, o paciente sairia o mínimo possível de sua região e, progressivamente, o máximo de atividades seriam oferecidas todos os dias e em todos os períodos do dia. Ao mesmo tempo que é "parte essencial desse modelo tanto a preocupação com a consciência sanitária dos usuários e da comunidade como com a humanização do atendimento" (4).

Nessa monografia se considera que o modelo assistencial que deve ser implementado para que as pessoas portadoras de deficiência possam ter acesso à atenção a sua saúde, deve ser aquele do Sistema Único de Saúde e que vem sendo construído; porque este poderia dar condições para que os serviços de saúde se ampliassem a ponto de abranger essa clientela.

No entanto, é importante explicitar como vêm se delineando os serviços de atenção a essa população no município de São 
Paulo, para que possa fazer uma discussão com referências mais concretas entre os serviços existentes e a perspectiva do S.U.S.

\section{3 - Os serviços de atenção à população portadora de deficiência no Município de São Paulo}

Conforme já foi mencionado, os serviços de saúde e reabilitação para as pessoas deficientes foram constituídos em sua grande maioria por iniciativa da sociedade civil e são, geralmente, de caráter filantrópico, com subsídios do setor público.

Para melhor visualizar a questão foi utilizado catálogo da APAE - Associação dos Pais e Amigos dos Excepcionais -, que em 1987 organizou uma listagem dos serviços de atenção à pessoa deficiente, que foi publicada em conjunto com a Secretaria de Estado da Saúde. Nesse catálogo estão discriminadas por regiões da cidade as clínicas de atendimento que contam com equipe especializada, as escolas e classes especiais, as oficinas de preparação profissional e as oficinas protegidas; bem como as instituições mantidas por associações de pais e de pessoas sensibilizadas pela problemática do deficiente.

$\mathrm{Na}$ Tabela 11, os serviços de atenção à pessoa deficiente estão apresentados de $A$ a $G$ e representam deferentes propostas de atenção a essa clientela com as seguintes características:

\section{A - INSTITUIÇÕES}

Entidades de atendimento mantidas por associações de pais ou amigos da pessoa, de caráter beneficente. A maior parte delas recebe subsídios do setor público através de verbas da Fundação Legião Brasileira de Assistência. Também mantém 
convênios com empresas privadas e com serviços de saúde de servidores públicas, como por exemplo: Hospital do Servidor Público Municipal e Estadual, Banco do Brasil, Metrô entre outros.

\section{B - AMBULATÓRIOS DE SAÚDE MENTAL}

são serviços próprios da Secretaria de Estado da Saúde que prestam atendimento às pessoas com sofrimento psíquico. Geralmente também mantém atendimento medicamentoso às pessas deficientes mentais.

\section{C - CLÍNICAS}

serviços particulares, que oferecem atendimentos multidisciplinares, que podem ser conveniados com o setor público e com empresas, utilizando o critério de classificação sócio-econômico para pagamento.

\section{D - ESCOLAS ESPECIAIS}

serviços privados financiados pelos familiares dos alunos, dispondo, às vezes, de equipe multidisciplinar para tratamento. Geralmente as mensalidades são definidas através de classificação sócio-econômica da família.

\section{E - CLASSES ESPECIAIS}

que funcionam nas escolas públicas estaduais de primeiro grau, para onde são encaminhados grande parte das crianças das classes comuns, mas que tenham problemas de aprendizagem. Existem classes especiais para crianças com deficiência mental (DM), com deficiência auditiva (DA), com deficiência física (DF) e com deficiência visual (DV)

\section{F - OFICINAS}


que desenvolvem atividades de caráter pedagógico e de pré profissionalização ou então atividades ocupacionais de caráter protegido.

\section{G - LAZER}

centros educacionais e esportivos vinvulados à Secretaria Municipal de Esportes, que desenvolvem, em algum período da semana, programação especial para pessoas deficientes. Instituições de caráter privado que organizam atividades culturais e de lazer. Aqui não está referido o Movimento Fé e Luz, da igreja católica, que congrega 50 paróquias visando a integração social do deficiente mental através de passeios e reuiniões em convivência com pessoas não deficientes.

Os serviços oferecidos, no município de São Paulo, estão caracterizados na Tabela 11.

TABELA 11 - Dos diferentes serviços de atenção à pessoa deficiente no Município de São Paulo, 1987.

\begin{tabular}{|c|c|c|c|c|c|c|c|c|c|c|}
\hline \multicolumn{11}{|c|}{ SERVIÇOS DE ATENÇÃO A PESSOA DEFICIENTE ** } \\
\hline \multirow[t]{2}{*}{ Região } & \multirow{2}{*}{$\begin{array}{c}\text { A } \\
\text { Institui- } \\
\text { ções }\end{array}$} & \multirow{2}{*}{$\begin{array}{c}\text { B } \\
\text { Amb. Saúde } \\
\text { mental * }\end{array}$} & \multirow{2}{*}{$\begin{array}{c}\text { C } \\
\text { Clinicas }\end{array}$} & \multirow{2}{*}{$\begin{array}{c}\text { D } \\
\text { Escolas } \\
\text { Esp. }\end{array}$} & \multicolumn{4}{|c|}{$\begin{array}{c}E \\
\text { Classes especiais }\end{array}$} & \multirow[t]{2}{*}{$\begin{array}{c}\mathbf{F} \\
\text { Oficinas }\end{array}$} & \multirow[t]{2}{*}{$\begin{array}{c}\text { G } \\
\text { Lazeı }\end{array}$} \\
\hline & & & & & DM & DA & DF & DV & & \\
\hline Norte & 1 & 4 & 3 & 5 & 108 & 11 & 7 & 1 & - & - \\
\hline Sul & 5 & 3 & 26 & 32 & 183 & 36 & 4 & 6 & 5 & 3 \\
\hline Leste & 2 & 4 & 5 & 6 & 115 & 28 & - & 3 & 1 & 1 \\
\hline Oeste & 2 & 2 & 9 & 2 & 11 & 3 & - & - & - & - \\
\hline Centro & - & 1 & - & 1 & 9 & 9 & - & - & - & 2 \\
\hline Total & 10 & 14 & 43 & 46 & 426 & 97 & 11 & 10 & 6 & 6 \\
\hline
\end{tabular}

FONTE: Assoc. de Pais e Amigos dos Excepcionais - APAE. Guia DM. SP.

São Paulo, Secretaria de Estado da Saúde, 1987.

${ }^{*}$ *) Nesse item o catálogo estava incompleto, foram acrescentados os ambulatórios que não estavam referidos. Os itens $A$ a $G$ foram esclarecidos anteriormente.

$\left({ }^{* *}\right)$ Não estão referidos os serviços de reabilitação do Hospital das Clínicas da FMUSP e da Santa Casa de São Paulo e as Unidade Básicas de Saúde da Secretaria de Estado de São Paulo. Cw12 
melhor equipada dispondo de todos os serviços apresentados. A região Norte, Oeste e Centro dispõe de um número bem menor de serviços, o que com certeza leva a que as pessoas dessas regiões, que necessitem de atendimento, tenham que se locomover para as regiões onde estão localizados, levando a longos e difíceis deslocamentos pela cidade.

O fato das regiões Sul e Leste disporem de serviços não significa que a demanda venha sendo atendida, pois mesmo assim os serviços são em números insuficiente. $O$ que significam 06 escolas especiais numa região de grande concentração populacional como a região Leste. E o fato de não haver, até 1987, nenhuma classe especial para a criança com problemas motores.

Mesmo na região Sul, que dispõe de 32 escolas especiais, 25 são destinadas a portadores de deficiência mental e problemas psiquiátricos e, as demais a crianças com problemas neuromotores e auditivos. É nessa região que está localizada a Escola Municipal Helen Keller para crianças com distúrbios auditivos. Isto significa que as crianças com distúrbios motores, que representam, segundo dados da PNAD 81, cerca de $24 \%$ das crianças deficientes de 0 a 09 anos em 1981, têm maior deficuldades de acesso à educação.

Existe um número maior de escolas com classes especiais para crianças com distúrbios visuais e auditivos apesar desses problemas acometerem um percentual menor de crianças na faixa dos 0 aos 09 anos de idade. Segundo dados do PNAD 81 (14), 7,58\% das pessoas com deficiência na região metropolitana de São Paulo têm entre 0 e 09 anos de idade, isto é, 14.109 crianças. As 534 classes especiais para essas criançasm referidas na Tabela 11, 
seriam insuficientes, mesmo porque desde então esse número de crianças vem crescendo.

As oficinas têm como objetivo lidar com a questão da profissionalização das pessoas. O fato de existirem apenas 6 , no município em 1987, demonstra que, possivelmente, a atenção prestada à população deficiente está centrada no tratamento, em especial até o final da adolescência. * $\mathrm{Na}$ fase adulta as pessoas, mesmo as que se submeteram a acompanhamento especializado, permanecerão no ambiente familiar apenas.

Ou seja, a insuficiência de serviços disponíveis para atenção à saúde, educação, lazer e profissionalização da pessoa deficiente demonstra o grau de dificuldade para a inserção dessas pessoas no contexto da vida social.

Nos serviços prestados apresentados na Tabela 11 não estão incluídos aqueles conveniados com a Previdência Social que prestam assistência médica e fisioterápica aos segurados, principalmente aqueles que sofreram acidentes de trabalho e que tenham desenvolvido doença profissional. Não dispomos de informações acerca dos serviços de atendimento de uma grande parcela da população em idade produtiva, que se constitue em cerca de $75 \%$ das pessoas deficientes, conforme demonstrou a Tabela 2.

Os serviços conveniados são responsáveis pela quase totalidade dos atendimentos prestados aos trabalhadores acidentados seja como simples assitência médica, seja junto a Secretaria de Estado da Saúde aqueles que estão incapacitados temporariamente. 
A previdência Social através do INPS - Instituto Nacional de Previdência Social - é responsável pelo atendimento de reabilitação profissional dos segurados que estão incapacitados temporária ou permanentemente. Para isso dispõe de apenas um Centro de Reabilitação Profissional para atender a região metropolitana de São Paulo e mais Sorocaba, São José dos Campos, Tatuí e Itapetininga entre outros municípios.

Ou seja, praticamente quase toda a atenção prestada a população deficiente é desenvolvida por serviços privados. Não estão garantidos pelo Estado os direitos sociais como: saúde, educação, trabalho entre outros. A possibilidade do exercício da cidadania ainda se dá nos moldes da cidadania invertida e regular, já apresentados.

\section{4 - A atenção à saúde da pessoa portadora de deficiência na rede pública - uma experiência}

Quando se fala em cidadania plena se fala também na luta pela garantia dos direitos mínimos que, em sí, representa uma forma de conquista dessa condição. Essa é uma luta que deve ser da grande parcela da população brasileira tendo em vista suas condições de vida e de acesso aos bens mínimos para a sobrevivência. Assim, entendemos que a possibilidade de se contar com um número maior e melhor de serviços de saúde, que atendam à população deficiente depende, diretamente, da ampliaçãodos serviços de saúde em número e em grau de resolutibilidade, isto é, serviços que desenvolvam o atendimento integral à saúde. Estes serviços de atenção à saúde da pessoa deficiente são parte dos serviços de saúde não devendo estar 
desvinculados destes, pois devem estar próximos dos locais de trabalho e moradia dessa população tendo condições de oferecer atendimento o mais próximo possível da realidade dessas pessoas e não favorecendo sua segregação.

Vem reforçar essa idéia o exemplo do Centro de Reabilitação da Santa Casa de Misericórdia de São Paulo que, em 1981, observou que dos 190 pacientes atendidos nos meses de agosto e setembro apenas 64 eram moradores da capital, os demais eram procedentes de cidades do interior, de outros estados e até de outros países da América Latina. Entre as dificuldades para continuidade do tratamento encontradas pelos pacientes moradores da capital as maiores estavam relacionadas com o transporte da moradia até o Centro (23).

A necessidade de criação de serviços descentralizados e regionalizados para pessoas portadoras de deficiência não é uma preocupação nova, mas de certa forma é recente no interior dos serviços públicos de saúde.

A partir de dezembro de 1984, como resultado de diferentes debates e discussões acerca da problemática das pessoas deficientes no âmbito da saúde, educação, trasnporte e lazer organizados pelos movimentos de defesa das pessoas deficientes e por grupos de profissionais que trabalham com o tema, a Secretaria de Estado de Saúde criou um grupo de trabalho para estudar, propor e implantar política de sistema de atendimento à saúde das pessoas com deficiência física e/ou sensorial (31).

Este Grupo de Trabalho fundamentou sua proposta na concepção de sistema de saúde descentralizado, regionalizado e hierarquizado, como forma de viabilizar uma rede mais ágil e que não se limitasse às ações mais comuns: de vacinação, 
acompanhamento de gestantes e crianças até 1 ano de idade e controle e tratamento de tuberculose e hanseníase. Assim, propos um sistema de atendimento dos deficientes em consonância com essa concepção mais geral (32).

O objetivo geral da proposta era, e ainda é, contribuir para a melhoria da qualidade dos serviços de saúde, desenvolvendo programas de prevenção da deficiência bem como do agravamento da mesma quando de sua instalação. Isto seria realizado mediante ações de atenção primária de saúde, detecção precoce, diagnóstico e procedimentos básicos de reabilitação e de integração social (33).

Essa é uma proposta, fruto das lutas dos movimentos em defesa da pessoa deficiente que tenta colocar na prática, com os limites muito objetivos dos serviços de saúde da rede estadual, a possibilidade do exercício da cidadania, no que tange aos aspectos da saúde, dessa população. É uma experiência bastante recente, com muitas dificuldades de implantação, que aponta como uma possibilidade de inserção do atendimento a essa população no sistema de saúde.

O estudo do desenvolvimento na prática dessa experiência, juntamente com as desenvolvidas no âmbito federal e municipal no Município de São Paulo oferecerá condições para reflexão sobre a inserção da atenção à saúde dessa população no sistema de saúde.

A seguir serão apresentadas as entrevistas realizadas nas diferentes esferas de atendimento a partir de onde se buscou construir um quadro sobre essa inserção. 
VI - ENTREVISTAS 


\section{1 - Apresentação e Discussão}

As entrevistas buscaram registrar as principais reflexões de profissionais inseridos em diferentes instituições e com diferentes responsabilidades no seu interior.

Os roteiros de entrevistas, em anexo, foram organizados de forma a poder proporcionar um perfil ampliado do pensamento desses profissionais e mostrarem-se adequados para delineamento desse perfil. Nesses roteiros foram levantados os seguintes aspectos:

política de saúde: - sua concepção

- concepção que está delineada na instituição

papel da instituição no sistema de saúde e na política de saúde atuais

inserção da atenção à saúde da pessoa portadora de deficiência no sistema de saúde

trabalho que é desenvolvido no interior dessa instituição e a relação com o atendimento a essa clientela

principais questões que se colocam para as instituições e para os profissionais que desenvolvem atendimento a essa clientela

sugestões para a implementação do trabalho da instituição

Iniciar-se-à a apresentação dos resultados a partir das entrevistas com profissionais da Secretaria do Estado, pois considerou-se que esta dispõe de proposta de sistema de atendimento à saúde e reabilitação da população portadora de deficiência, já delineada, com Grupo de Trabalho especialmente constituído para isso, desde 1984. A partir de 1985 esse Grupo vem apresentando essa proposta para a rede de serviços estaduais de saúde. 
Foi adotado o seguinte ordenamento:

1 - Entrevistas realizadas com os profissionais da Secretaria de Estado da Saúde.

1.1. Membros do Núcleo Operativo do Gepro Saúde da Pessoa Deficiente

1.2. Representantes dos Gepros afins

1.3. Diretores de SUDS onde se desenvolvem ações de saúde com a população portadora de deficiência

1.4. Coordenadores do programa nos SUDS

1.5. Diretores de UBS onde se desenvolve o programa

1.6. Profissionais que atendem diretamente a população

2 - Entrevistas realizadas com profissionais representantes das instituições que tradicionalmente, atendem à população portadora de deficiência.

3 - Entrevistas realizadas com profissionais representantes da área federal

4 - Entravistas realizadas com profissionais representantes da rede municipal.

Segue-se a apresentação das reflexões apresentadas nas entrevistas.

1.1. Entrevistas Realizadas com Profissionais da Secretaria de Estado da Saúde

\subsubsection{Entrevistas com os Membros do Núcleo Operativo do Gepro Saúde da Pessoa Deficiente}

Iniciamos com esse grupo porque é o responsável pelo delineamento e acompanhamento da proposta de atenção a essa população. Foram entrevistados os 5 profissionais vinculados ao Núcleo Operativo do Gepro Saúde da Pessoa Deficiente a partir do roteiro de entrevistas 1.

Observamos que a concepção de política de saúde predominante 
é aquela com as diretrizes gerais do sistema único de saúde: universalização do direito à saúde, com ações desenvolvidas de maneira unificada, descentralizada e regionalizada. Está presente 0 fato de que o SUDS é uma proposta que se implanta lentamente, com problemas de cobertura da população e qualidade dos serviços prestados. No entanto, apenas uma pessoa reconhece como política de saúde algo que extrapola o setor saúde, que está ligada às condições de produção de saúde e não restrita às ações com relação às doenças, que é delineada de uma maneira global como proposta de governo, integrada pelos esforços de diferentes Secretarias. Também foi observado que um dos entrevistados tem concepção de política de saúde que se refere às consequências do não estabelecimento de uma política voltada para a realidade e que se apresentou mais como uma apreciação ao desenvolvimento de política de saúde em particular. Ao mesmo tempo existe a concepção de que a política de saúde é o conjunto dos pensamentos de quem trabalha no setor sobre as necessidades de atendimento à saúde da população. Ou seja - a política seria a somatória dos diferentes pensamentos, onde cada profissional teria o mesmo acesso a sua definição.

\section{Sobre a política de saúde que permeia a Secretaria de}

Estado as opiniões se dividem entre a Secretaria não ter uma política de saúde única (visto trabalhar tradicionalmente com alguns grupos: como crianças e gestantes e atualmente tentar incorporar as ações curativas que vem mudando o perfil das UBS inclusive, como forma de responder à pressão da população) e a tentativa de implementação do SUDS (que para eles seria uma somatória de 
diferentes concepções dos seus princípios básicos e que vem se desenvolvendo com insuficiência de recursos tanto humanos quanto materiais).

Sobre a concepção de política de saúde necessária ao desenvolvimento do programa observamos que a maioria concorda que não deve existir concepção de política de saúde especial. Que, se o SUDS fosse levado a cabo, seria produtivo para o desenvolvimento do programa. Ao mesmo tempo que os demais consideram que é fundamental que a concepção de saúde seja integral, não apenas para a pessoa deficiente e que a atenção à saúde tenha como suporte a não fragmentação e especialização que dificultam 0 atendimento da pessoa deficiente em suas necessidades gerais, pois se priorizam apenas as especiais.

É importante salientar que pelas respostas a esta questão, fica patente que 0 mais produtivo para o programa seria que 0 SUDS fosse implementado, apesar de se reconhecer na questão anterior que este se apresenta como uma somatória de diferentes concepções de integração interinstitucional, descentralização e regionalização. Também seria produtivo ao programa, e talvez ao próprio SUDS propor ações de saúde a partir de uma concepção integral, pois as ações curativas, como as de pronto-atendimento e pronto-socorro invibializariam o trabalho junto a essa população.

$\mathrm{Na}$ questão seguinte sobre a relação existente entre 0 programa de saúde da pessoa deficiente e os demais programas reconhece-se que, em termos teóricos, existe relação com os demais programas, mas que na prática o que ocorre é um 
discurso de integração, pois os Gepros tem peso político diferente nas diferentes esferas de poder da Secretaria. Também se reconhece que a relação entre os programas está colocada para as ações preventivas, principalmente no que diz respeito à origem das deficiências. Também existe a concepção de que não deveria haver um programa específico para as pessoas portadoras de deficiência, pois ele se constitui de ações que são parte de diferentes programas. Um programa específico torna-se necessário pelo fato de que nunca foi realizado trabalho com essa clientela, mas o passo posterior seria a integração trabalhando-se numa programação única.

Observamos nessas respostas uma concepção equivocada de integração, onde esta passaria, necessariamente pelo trabalho conjunto dos Gepros. No entanto, consideramos que a integração é algo que deve ocorrer na prática das UBS, no cotidiano do trabalho, e não resultado da somatória dos diferentes grupos.

O atendimento desenvolvido deve considerar o individuo integralmente, existindo também espaço para ações específicas. Assim sendo, a inclusão do atendimento à pessoa portadora de deficiência na rotina das UBS não pode ser vista apenas pelo desenvolvimento de ações preventivas como: vacinação, acompanhamento do desenvolvimento infantil, atenção pré e pós natal de qualidade entre outras. A inclusão do atendimento às necessidade específicas dessa população não pode ser considerada simplesmente como resultado do desenvolvimento das ações preventivas pois há que se dar respostas próprias a essas necessidades específicas incorporadas práticas até aqui não 
desenvolvidas na UBS.

É na avaliação da implantação do programa onde se observa que existe uma certa unanimidade em considerar que este tem maior deficuldade no município de São Paulo pelo fato da prioridade ser a constituição dos Núcleos de Atenção Integral (NAI) junto dos SUDS, da municipalização não ter-se concretizado e da existência de muitas instituições que, tradicionalmente, vem atendendo essa população, mesmo que com pequena cobertura populacional. A não prioridade do programa leva à destinação de recursos insuficientes nos diferentes SUDS para contratação de profissionais, compra de equipamento, reformas para adaptação de espaço físico como também a um esforço redobrado por parte do Gepro no trabalho de sensibilização dos derigentes das regiões para a questão.

$\mathrm{Na}$ avaliação do programa no tocante a insumos e recursos disponíveis é reconhecida a necessidade de contratação e treinamento de profissionais para atendimento dessa clientela priorizando uma abordagem de saúde coletiva. Também é reconhecida a necessidade de UBS com espaço físico adaptado ao uso da clientela e suficiente para incorpotação das equipes de reabilitação, o que somente ocorreu naquelas que foram projetadas e construídas pelo Programa Metropolitano de Saúde e que respeitaram a destinação de área física para atendimento em reabilitação. Quanto a recursos financeiros acredita-se que se tenha a mesma escassez que nos demais programas e que existe grande descoordenação entre as orientações do Gepro para compra 
de equipamentos e materiais e o processo de sua aquisição em nível regional.

Os membros do Gepro apontam, como necessidades a serem satisfeitas para melhor desenvolvimento do programa: 0 constante trabalho de sensibilização das autoridade sanitárias, das direções regionais, locais e das equipes das UBS para a problemática da pessoa deficiente; maior investimento do serviço público na área; supervisão e acompanhamento constante dos locais que atendem essa população; como também a contratação de profissionais e seu treinamento. Além disso é necessário que haja espaço físico adaptado nas UBS e que a proposta SUDS se consolide. Ou seja apontam para a necessidade de delineamento de uma política de atendimento à saúde dessa população, pois a existência dessa proposta de programa não tem se consolidado na prática dos serviços das regiões de saúde.

\subsection{2 - Entrevistas com Representantes dos Gepros que estão Relacionados à Problemática da Pessoa Portadora de Deficiência.}

Foram entrevistados um representante de cada um dos seguintes Gepros: Saúde da Criana, Saúde do Trabalhador, Doenças Crônico-Desenerativas, Saúde Mental, Ortopedia e Traumatologia e Hanseníase, usando o roteiro de entrevista 5.

Quando questionados sobre a sua concepção de Política de Saúde, referem que esta representa a pressão da sociedade, que deve ser suprapartidária para se evitar seu uso político, que 
depende da concepção de saúde e de sistema único de saúde, que é aquela que está delineada nos documentos oficiais pois se referem às necessidades reais da população. Isto é, apresentam sua concepção de forma extremamente ampla sem caracterizá-la ou então apresentam-na, já um pouco mais delineada, como aquela que contém os princípios básicos da regionalização, hierarquização e universalização ou aquela que se assemelha ao SUDS, que deve ter bases epidemiológicas. Ou então, como o conjunto das diretrizes que vão estabelecer ações executivas para a melhoria das condições de saúde e da qualidade de vida de uma população. Ou ainda, a partir do delineamento do papel da rede pública (atendimento aos agravos que envolvam maiores custos) e da rede privada e da necessidade de ser aplicada ao modelo político do país. Ou seja, as concepções são genéricas e reduzem política de saúde à prestação de serviços de saúde e à sua operacionalização. Não incorpotam a política de saúde como resultante da política econômica e das políticas de diferentes setores como meioambiente, alimentação, educação entre outros.

\section{Quanto à política de saúde desenvolvida pela Secretaria} observamos que igualmente se reconhece que é aquela baseada nos princípios de universalização e hierarquização esbarrando em interesses ideológicos, sendo desenvolvida com dificuldades; que evolui das AIS (Ações Integradas de Saúde) para o SUDS; que prioriza a municipalização; que inicialmente pretendia absorver todas as atividades de saúde, mas que atualmente percebe a necessidade de maior espaço para iniciativa privada e que assume ações curativas que não eram desenvolvidas anteriormente. 
Observamos que essas diferentes respostas abragem os principais aspectos da Política de Saúde dos documentos oficiais.

Na questão como deve se inserir a atenção à saúde da pessoa portadora de deficiência, percebemos que prevalece a idéia da não discrimnação do deficiente; do direito universal à saúde; da necessidade do Estado criar oportunidades de reabilitação ao mesmo tempo que um entrevistado entende que a inserção depende do conceito de deficiência, seu significado epidemiológico, da pressão social dessa população, da política que a sociedade tem para com essa população, além dos recursos disponíveis. Ou seja, é como se não fosse conhecida a importância epidemiológica da deficiência e a pressão social não fosse suficiente para o delineamento de um tipo de inserção e a consequente liberação de recursos. Isto é, mantém-se uma postura de questionamento, sem definição de proposta para o problema.

Quanto à relação entre o programa e 0 trabalho desenvolvido pelo respectivo Gepro, observamos que igualmente se aponta a necessidade de maior integraçao entre os Gepros; que já foram realizadas algumas ações conjuntas e que é necessário maior integração dos diferentes programas para que o atendimento à clientela seja mais integrado e esta não deja discriminada.

No entanto sobre a relação do programa com os demais programas reconhe-se que as pessoas com deficiência têm os mesmo problemas de saúde que as demais, devendo participar dos mesmos serviços para não serem marginalizadas; e que não se conhece o trabalho do Gepro Saúde da Pessoa Deficiente, o que por 
sí só seria um impedimento para a necessária integração apontada na questão anterior. Ao mesmo tempo, também fica claro que é preocupação prioritária deste Gepro o intercâmbio com os demais.

Quanto às sugestões apresentadas, reforça-se a necessidade de que se estude o tema; de maior integração entre os Gepros e de maior incentivo à participação da pessoa portadora de deficiência no delineamento de propostas de atendimento e na pressão social sobre os serviços. Metade das pessoas não apresentou sugestões.

É importante salientar que pelas respostas às questões fica claro que, apesar do discurso da maior integração no trabalho dos diferentes Gepros e da necessidade de inserção da clientela portadora de deficiência entre os usuários dos serviços de saúde, a integração não é uma questão fundamental, nem está colocada como um problema a ser lidado no interior dos Gepros, situados que são na propria assessoria direta do Secretário.

\subsection{3 - Entrevistas com os Diretores de SUDS onde se Desenvolvem Ações de Saúde com a População Portadora de Deficiência.}

Foram entrevistadas 4 diretores de SUDS utilizando-se 0 roteiro de entrevista 3.

A concepção de política de saúde dester diretores se coloca igualmente como: as diretrizes que o governo apresenta para garantir o direito à saúde, como fruto do discurso técnico das corporações, mas que na prática é resultante da correlação das forças políticas em cada momento histórico. Ou então como aquela 
que contém os princípios clássicos da atenção integral como garantia do direito à saúde devendo buscar ações e estratégias que garantam a concretização dos princípios. Ou ainda como o conjunto das ações a serem desenvolvidas pelo orgão gestor federal, estadual ou municipal - com base no perfil epidemiológico e respeitando as questões regionais, que serão lidadas segundo a capacidade de financiamento e investimento levando em conta as ações de maior impacto possível.

$\mathrm{Na}$ questão sobre a política de saúde da Secretaria, reconhece-se que é aquela que tenta lidar com a implantação do SUDS, desde 1986, onde a UBS é a porta de entrada, com um modelo assistencial calcado na atenção integral, que tem dificuldade de implantação, pois é necessário um volume maior de investimento para diminuir o sucateamento e a capacidade ociosa dos serviços público e onde se prioriza a integração e regionalização dos serviços. No entanto, a prática real da regionalização tem que ser conquistada porque o poder ainda está centralizado. Aponta-se também que se vive um momento de transição onde os objetivos ainda não foram alcançados. Ao mesmo tempo existe a concepção de que a política desenvolvida é aquela que está de acordo com as necessidades reais da população que hoje se traduziria na implantação dos pronto atendimento em todas as UBS do Estado.

Quanto à inserção da atenção à saúde dessa população no sistema de saúde predomina a idéia de que deva se dar da mesma forma que para todas as pessoas, onde se deve discutir desde a prevenção até a reabilitação, tendo como perspectiva a integralidade das ações. Reconhece-se que não é necessário nem 
produtivo o atendimento verticalizado, mas deve-se respeitar as especificidades dessa população. Também se considera que a atenção à essa população tem destaque por questões culturais, pelo abandono em que se encontra e pelo fato de que não está inserida na atenção à saúde em geral.

No que diz respeito à relação do programa com as demais ações de saúde foi referida a resistência que as equipes das UBS têm em atender a essa clientela. Quando o atendimento ocorre tanto a equipe quanto a própria clientela sofrem um certo isolamento como nos Programas de Saúde Mental e Saúde do Trabalhador. Para lidar com isso serial necessários programas de treinamento para as equipes. Alguns já foram iniciados com grupos de pediatras no SUDS 6, tratando sobre a detecção precoce de deficiência. Também foi levantada a existência de ações gerais de saúde junto a pessas hipertensas e diabéticas, que teriam caráter preventivos de incapacidade e deficiência, no entanto, é necessário incorporar outros profissionais (como fisioterapeutas e terapeutas ocupacionais) nos serviços para dar maior resolutibilidade às ações de tratamento. Metade dos diretores não conhecia o detalhamento do programa, mas sugeriu que fosse consultado o seu coordenador na região.

Quanto à avaliação do programa na região reconheceu-se igualmente, que não existe desconhecimento ou preconceito do SUDS em relação à proposta, mas sim falta de recursos; que é necessário maior previsão orçamentária para planejar essa proposta de programa, que as ações junto a essa clientela ainda estão à margem dos serviços públicos. Ao mesmo tempo também se 
Apontou que os projeto-piloto do SUDS 6 e 7 são precários e não cobrem a demanda; que estão em fase de implantação que esta é bastante demorada devido à lentidão para a admissão de profissionais e para realização de adaptação no espaço físico. Também se reconheceu que é grande a rotatividade de profissionais e que estes não têm experiência em saúde pública havendo necessidade de se investir na sua formação.

Nas sugestões apresentadas apontou-se a necessidade de que o sistema de saúde realmente funcione com número mínimo de leitos hospitalares, com maior controle das causas de deficiência entre outras para que seja possível oferecer atendimento a essa clientela. Também se coloca a importância de não se criar atendimento verticalizado e de que em cada SUDS houvesse 0 programa com Centro de Reabilitação de referência e equipe de profissionais nas UBS.

Percebemos que os diretores de SUDS reconhecem a necessidade de atendimento à saúde dessa população de forma integrada nos serviços de saúde e que é preciso implantar a proposta SUDS como requisito para o desenvolvimento do programa, mas não falam em prazos, metas estabelecidas juntamente com os coordenadores de programa. Parece até que este é tão prioritário quanto os demais ou então não ocupa o terreno das preocupações desses gerentes, pois toda demora e lentidão é justificada e em nenhum momento se analisa esse fato. 


\subsection{4 - Entrevistas com os Coordenadores do Programa nos SUDS}

Foram realizadas 4 entrevistas utilizando-se o roteiro de entrevistas 3.

Os coordenadores consideram que: política de saúde são os caminhos escolhidos em nível federal, estadual ou municipal pelos quais se delimita as ações de saúde, seu financiamento e custeio. Ou ainda, seria atender às necessidades locais de saúde a partir de um diagnóstico de saúde e também responder às expectativas das necessidades de saúde de uma determianada população. A metade deles considera que a estratégia utilizada pela instituição para implantar uma sistemática assistencial, seria a das diretrizes da VIII Conferência Nacional de Saúde para implantação da atenção primária, da relionalização, da descentralização e da universalização.

Estas são concepções bastante gerais e que algumas vezes confundem princípios com execução de programas.

Na questão sobre qual é a política de saúde da Secretaria, as opiniões se dividiam igualmente entre: aquela que tenta agilizar alguns pontos da VIII Conferência como a incorporação da assitência médica curativa ao setor público, aquela que reconhece que é uma política que tem um cunho empresarial e que está dificultada pelas pressões tanto internas quanto da inicitiva privada. Também se aponta que houve um retrocesso na constituição das regiões e dos distritos, pois há maior empenho nas ações centralizadas (Gepros) e que a política tem levado a menor participação dos técnicos nas decisões, que continuam 
Centralizadas. Outra opinião é que a política viria do SUDS como caminho para o SUS, através da reforma administrativa (ERSAS) com maior descentralização de poder. Ainda outra, que seria mais teórica onde a prioridade é a atenção global, mas na prática é o incentivo à produtividade com qualidade questionével e com maior volume de recursos disponíveis para o sistema.

A última opiião seria que, anteriormente, a política seria para as ações preventivas e hoje a maior prioridade é a contração de equipe médica e compra de equipamentos para as ações curativas. Ou seja, existe cerca unanimidade de que a prioridade dessa política são as ações curativas e onde o SUDS aparece como o arcabouço para a implantação da política, mesmo que sem poder real.

No entender dos coordenadores a atenção à população portadora de defiência deve se inserir no sistema de saúde como a atenção à saúde de qualquer outra pessoa, pois uma inserção diferenciada a implementação das ações. No entanto, existe necessidade de pensá-las nos diferentes níveis de complexidade como corpo técnico próprio e recursos materiais articulados, apesar de se reconhecer que existem obstáculos por parte das equipes de profissionais das UBS para 0 atendimento dessa clientela nas questões mais usuais de saúde. Existe opinião contrária à criação de programa específico, pois mais racional seria separar os programas por especialistas e trabalhar pensando em diferentes grupos populacionais como crianças, mulheres e adultos. 
$\mathrm{Na}$ questão sobre a relação do programa com as demais ações de saúde metade dos coordenadores defende a incorporação dos profissionais da equipe de reabilitação à UBS e não a um programa. Outro coordenador propõe que não se contrate para programa e sim para UBS como em sua região e outro refere que como em sua região ainda não existe o programa completo, existem algumas ações desenvolvidas conjuntamente com os demais programas como gestantes, hanseníase, etc...

Na avaliação da implantação do programa na região: nas duas regiões do SUDS 4 e 3 , Penha e Vila Prudente respectivamente, vem se trabalhando no levantamento de dados para diagnóstico da situação há mais de um ano e ainda não existe perspectiva de implantação, pois a prioridade é o atendimento médico dos pronto-atendimentos. No SUDS 7 - Freguesia do Ó apenas uma UBS tem equipe incompleta; mas a partir de fevereiro de 1990 haveria equipe completa em diferente UBS.

No SUDS 6 - Tucuruvi, a avaliação é positiva, existe uma equipe de referência para um módulo*. Aponta-se que a hegemonia do atendimento médico nas UBS tem dificultado a implementação do trabalho.

As tabelas 12 e 13 demonstram a situação geral do programa quanto ao nível de implantação e quanto a recursos humanos e espaço físico disponível para o seu desenvolvimento, nos diferentes SUDS do Município de São Paulo.

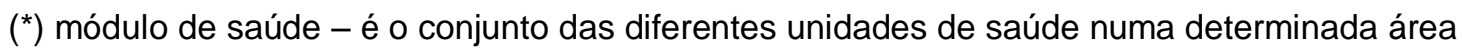
geográfica. Cada SUDS é composto por diversos módulos. 
TABELA 12 - Nível de implantação do atendimento à saúde da clientela, segundo as regiões de saúde da Secretaria de Estado da Saúde, no município de São Paulo, dezembro de 1989.

\section{Nível de implantação}

- com discussão em nível regional $x$

- com coordenador(a) das ações de reabilitação designado(a) em nível regional

- com profissionais contratados que desenvolvem algumas ações junto à clientela

- com equipe de reabilitação

* SUDS - Sistema unificado e descentralizado de saúde, corresponde a uma região (área geográfica) da cidade 1 - Sé

2 - Lapa, Perdizes, Butanta

3 - Vila Prudente

5 - Itaquera

6 - Mandaqui

4 - Penha
SUDS*

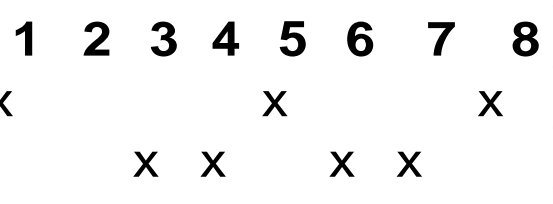

X X X

A maior parte das regiões de saúde da Secretaria de Estado tem algum tipo de ação junto a essa clientela, mas desenvolvida em espaço físico inadequadoe com equipes incompletas de profissionais vinculados ao programa.

As sugestões apresentadas falam da necessidade de implantação de uma política salarial mais adequada que fixe os profissionais nas UBS mais periféricas, que em cada SUDS houvesse coordenador do programa com interesse na área, que nas UBS escolhidas para implantação do programa as direções tenham interesse real na questão pois serão enfrentados muitos obstáculos e que se amplie o quadro de recursos humanos para 0 programa. Além do que se considera que o sucesso da proposta depende da prioridade estabalecida pelo SUDS, da cobrança e pressão da população. 

atendimento à saúde da clientela e de disponibilidade de profissionais contratados; segundo as regiões de saúde da Secretaria de Estado da Saúde no Município de São Paulo, dezembro de 1989.

\begin{tabular}{lrrrrr}
\hline Disponibilidade de profissionais & SUDS & & \\
e de espaço físico & 2 & 3 & 4 & 6 & 7 \\
\hline
\end{tabular}

1 - com profissionais ligados ao programa

de prevenção de incapacidades em

hanseníase

a) com fisioterapia

b) com terapeuta ocupacional

2 - Espaço físico

a) adequado *

b) inadequado **

$x \quad X$

$\mathrm{X} X$

3 - Com equipe para o programa de

atendimento à pessoa portadora de deficiência

a) completa

com espaço físico adequado

com espaço físico inadequado

b) incompleta ${ }^{\star \star \star \star}$

em espaço físico adequado

$x^{x}$ em espaço físico inadequado

pelo menos com duas salas de atendimento

** apenas uma sala de atendimento para todos os profissionais

*** com fisioterapeuta, fonoaudiólogo, psicólogo e terapeuta ocupacional

**** onde falta ou fisioterapeuta, ou fonoaudiólogo ou terapeuta ocupacional

\subsection{5 - Entrevistas com Diretores de UBS onde se desenvolve o}

\section{Programa}

Foram realizadas 4 entrevistas através do roteiro de entrevistas 3.

Os diretores de UBS consideram que política de saúde é a linha de ação nessa área que será assumida pelo Secretário, ou aquela que é voltada para a reversão total dos agravos à saúde desde o acompanhamento curativo até preventivo; ou ainda as diretrizes da última conferência nacional de saúde onde o nível 
local tem cada vez mais responsabilidade de ação junto à população; ou então é o SUS e não o SUDS, pois é necessário que a região tenha autonomia de pensamentos, de organização e de recursos financeiros.

Para a questão sobre política de saúde da Secretaria as opiniões se dividem igualmente entre: implantar a descentralização onde os níveis local e regional têm maio poder, mas os entraves ocorrem por diferentes concepções de descentralização; seguir a visão de SUS da constituição federal apesar das diferentes concepções e das muitas implicações de origem política no SUDS que é recente e desperta resistências nas diferentes esferas estaudal, federal e municipal; dar maior ênfase ao trabalho curativo, com grande exigência de produção de serviços sem a correspondente qualidade; desenvolver o SUDS mas a nível local não define as prioridades e o pronto atendimento "engole" o trabalho dos programas e assim se mantém uma política centralizada sendo os diferentes Gepros também um exemplo disso.

Metade dos diretores considera que a inserção da atenção à saúde dessa população no sistema de saúde deve ser igual a de qualquer pessoa, mas no entanto reconhecem que existem até barrerias arquitêtonicas nas próprias UBS. Os demais diretores não se referiram a essa questão.

Quanto ao desenvolvimento do programa na UBS em apenas uma delas existe completa atendendo à demanda da unidade em hanseníase apenas; em mais duas existe equipe incompleta que desenvolve ações junto à demanda da UBS e numa outra alguns 
profissionais da equipe foram contratados, mas não dispõem de equipamento e espaço físico para atender à clientela.

A relação do programa com as demais ações desenvolvidas na UBS só ocorre onde o programa está minimamente organizado conforme resposta à questão anterior.

As sugestões apresentadas pelos diretores referem a necessidade de municipalizar os serviços de saúde, fortalecer o SUS e ter política salarial e de recursos humanos melhor definida. Além de ser necessária a descentralização real com participação de funcionários e da população. Também é preciso que existam tempo e recursos financeiros para investir em espaço físico, materiais, equipamentos e recursos humanos; é urgente que haja maior ampliação dos serviços secundários e terciários de referência para retaguarda geral das UBS. Também foi referido que seria de extrema utilidade que o Gepro preparasse material para divulgação de pequenas orientações sobre como lidar com a clientela para serem utilizadas por qualquer profissional das equipes já existentes.

Percebemos que grande parte das colocações dos diretores de UBS coincide com as dos demais entrevistados, mas percebe-se que estes se apresentam, como profissionais que são, atados às dificuldades do cotidiano do trabalho e que não revelam caminho ou propostas para a questão. Ou seja, apenas refletem sobre a realidade do programa. 


\subsection{6 - Entrevistas com os Profissionais que Desenvolvem Atendimento à Clientela}

Foram entrevistados 14 profissionais(1 assistente social, 6 fisioterapeuta, 2 fonoaudiólogo, 1 psicólogo e 4 terapeutas ocupacionais) usando-se o roteiro de entrevistas 4.

A formação e experiência profissional anterior estão descritos na tabela 14 onde se observa que a maior parte dos profissionais (42,85\%) estão graduados no período entre 03 e 06 anos; têm experiência profissional anterior junto à clientela portadora de deficiência (57,14\%). Apenas 28,57\% tinha experiência de trabalho anterior em serviços públicos de saúde.

Tabela 14 - Tempo de graduação e experiência profissional dos técnicos que atendem a clientela nos SUDS, dez. 1989.

\begin{tabular}{cccc}
\hline I - Graduado há: & Até 02 anos & 4 & $(28,6)$ \\
& 03 a 06 anos & 6 & $(42,8)$ \\
07 a 10 anos & 3 & $(21,4)$ \\
mais de 10 anos & 1 & $(7,2)$ \\
\hline Total & 14 & 100 \\
\hline II - Experiência de trabalho junto à clientela portadora de \\
deficiência, antes do ingresso em serviço público \\
Sim & 8 & $(57,1)$ \\
Não & 6 & $(42,1)$ \\
\hline Total & 14 & 100 \\
\hline III - Experiência de trabalho em serviços públicos de saúde \\
Sim & 4 & $(28,6)$ \\
Não & 10 & $(71,4)$ \\
\hline Total & 14 & 100
\end{tabular}

Para esses profissionais a concepção política de saúde se apresenta como: diretrizes gerais de saúde; série de programas criados sem consulta e que não se adaptam à realidade da clientela; sendo confusa com boas idéias que não se viabilizam na 
prática; como aquela que prioriza a assistência médica com prejuízo para o desenvolvimento de programas; ou a que se define a partir do trabalho independente e sem coordenação dos profissionais de uma mesma UBS; como não oferecendo espaço de ação para os não médicos; como não existindo política de saúde e sim de doença.

Ao mesmo tempo esses profissionais referem que política de saúde deveria ser: dar atendimento de bom nível tanto preventivo quanto curativo; pensar em todas as áreas em termos de atendimento geral porque saúde englobaria tudo; tudo o que é oferecido à população; é dar conta da saúde da população de diferentes maneiras segundo a concepção de modelo assistencial: é ter UBS com espaço físico, materiais e profissionais contratados e é também planejar e criar estratégias para implantar ações dirigidas às necessidades da comunidade; sendo também as diretrizes básicas e a vontade política do próprio governo em criar uma política geral dirigida para a saúde, com as atividades da iniciativa privada ordenadas e não privilegiando o lucro. Ou seja, são concepções que mesclam conceito de planejamento e programação em saúde com política, no sentido das diretrizes gerais. No entanto, esses profissionais referem-se quase que da mesma forma à política de saúde que os demais já referidos que têm maior inserção e responsabilidade no delineamento de ações de saúde, pois se encontram em postos de mando.

A vinculação dos profissionais ao programa está apresentada na tabela 15, onde 05 deles não conhecem o programa, 2 o conhecem, mas não estão vinvulados diretamente a ele, 3 foram 
contratados como profissionais da equipe da UBS e também desenvolvem ações junto a essa clientela.

Além desses, mais 04 foram contratados para o programa, sendo que 03 deles participam dos trabalhos da equipe da UBS e não somente do programa e 01 deles desenvolve algumas ações do programa, apesar deste não estar implantado na UBS.

Tabela 15 - Das respostas - dos profissionais que atendem à clientela - à questão: Qual a sua vinculação ao programa de atendimento à pessoa portadora de deficiência

1 - Não conhece o programa

1.1 - e ainda não atende nenhum

cliente porque não dispõe de equipamento e espaço para tal 1.2 - mas atende clientela portadora de deficiência por iniciativa própria

1.3 - mas atende aos hansenianos

e a algumas pessoas portadoras

de outras deficiências por

iniciativa própria

1.4 - e foi contratado para o atendimento ao idoso

2 - Conhece o programa

2.1 - e atende além dos hansenianos algumas pessoas portadoras de deficiência por iniciativa própria

3 - Foi contratado como profissional da

UBS e participa do atendimento dessa clientela

4 - Foi contratado como profissional do programa e desenvolve algumas ações com essa clientela apesar do programa não estar implantado na UBS 5 - Foi contratado como profissional do programa dele participando, mas atualmente a equipe da UBS prioriza o trabalho com a clientela da UBS e não o desenvolvimento de programas isolados 


\section{A contribuição que os profissionais podem dar ao}

programa está relacionado por 05 pessoas, ao desempenho de seu papel profissionalm qualidade junto a clientela e à equipe. Por outro lado 02 pessoas consideram que por não possuírem experiência com essa clientela não podem contribuir mas não dispõe de material e espaço físico para trabalhar. Existem aqueles que se dispõe a participar das discussões no SUDS sobre integração dessa população no atendimento.

Os profissionais descrevem o cotidiano como repleto de atendimento à clientela seja individualmente seja em grupos específicos com pessoas portadoras de deficiência ou em grupos de orientação e acompanhamento junto aos demais clientes como: desnutridos, hipertensos, diabéticos ou idosos. Também participam das reuniões das equipes técnicas da UBS. Alguns profissionais encontram-se desanimados, pois tem que estar constantemente "à caça" de pacientes, porque o serviço médico não tem encaminhado os pacientes para o trabalho de prevenção de incapacidades e acompanhamento.

No geral a clientela é descrita como "carente" com baixo nível sócio-econômico e em sua maioria sem condições de arcar, se quer com as despesas de transporte até a UBS. A faixa etária varia entre adultos para 0 atendimento de prevenção de incapacidades das pessoas hansenianas e também para 0 tratamento e reabilitação de pessoas com sequelas neurológicas por acidente vascular cerebral ou idosos, e crianças com atraso no desenvolvimento neuro-psico-motor, distúrbios de comunicação, paralisia cerebral ou acometidas de algumas síndromes como 
Síndrome de Down e outras mais raras.

Normalmente trabalha-se com a demanda espontânea e os profissionais não tem uma idéia muito clara do número de pacientes que são acompanhados por eles ou pela equipe da UBS, o que também confere ao programa ou às ações que nele são realizadas um caráter de acompanhamento individual, que não se diferencia daquele oferecido pelas demais instituições privadas ou filantrópicas.

As sugestões apresentadas relacionam-se à melhoria das condições salarias e de trabalho, além da contratação de novos profissionais e da ampliação do número de UBS que desenvolva ações junto a essa clientela.

1.2 Entrevistas Realizadas com Profissionais das Instituições que Tradicionamente atendem à Clientela

Foram realizadas 8 entrevistas, usando 0 roteiro de entrevistas 6.

$\mathrm{Na}$ apreciação do trabalho desenvolvido no interior da instituição pode-se perceber que estas têm uma rotina de atendimento bastante complexa, porém previamente proposta e desenvolvida onde a clientela chega após minuciosos processos de triagem. Não iremos descrever aqui essas rotinas porque não é objetivo deste trabalho deter-se neste aspecto. A maior parte destas instituições trabalha com demanda espontânea, apresenta lista de espera ou número insuficiente de vagas e também desenvolve acompanhamento tanto em saúde quanto em educação, a médio e longo prazo.

Todas as instituições filantrópicas referem extrema 
didificuldade para a sua manutenção financeira, principalmente porque trabalham com clientela de baixo poder aquisitivo e atendimento de alto custo por sua complexidade. Também apontam que o valor pago pelos convênios com instituições públicas como: bosas de Fundação Legião Brasileira de Assistência, IAMSPE Instituto de Assistência Médica do Servidor Público Estadual ou mesmo com o INAMPS, são insuficientes para a cobertura de seus custos. Todas recorrem à realização de festas ou feiras beneficentes e à adesão de associados como forma de recolhimento de fundos para financimento de suas respostas. Apenas a DRPV Divisão de Reabilitação Profissional Vergueiro, ligado ao Hospital das Clínicas da Faculdade de Medicina da USP é mantida pelo orçamento estadual em convênio com o SUDS. Atualmente, vem se desenvolvendo nessa instituição uma proposta de implantação de atendimento a particulares.

Ao abordar o papel que a instituição desempenha na atenção à saúde da pessoa portadora de deficiência, as opiniões em sua grande maioria, apontam que é seu papel desenvolver a atenção em nível terciário (reabilitação), a formação de recursos humanos (pois algumas são instituições vinculadas ao ensino); demonstrar para a comunidade a necessidade de maior consciência sobre a prevenção diagnóstico correto e tratamento da deficiência e o potencial de habilidades da pessoa portadora de deficiência. Apenas uma instituição, além daquele papel já descrito, é de parecer que sua função é prestar atendimento à essa população que não dispõe desses serviços no setor público.

No que tange a como deve se inserir a atenção a atenção à saúde dessa população no sistema de saúde, as opiniões convergem para a 
atenção integrada nos mesmos serviços de saúde que atendem à população em geral desde que em diferentes níveis de complexidade, e de forma regionalizada com equipes de profissionais capacitados. Também é apontado que o setor público não atende às questão mínimas de saúde como: vacinação e atenção à gestante entre outras e por isso necessita da colaboração interinstitucional com essas entidades que deveriam ter seus serviços custeados pelo INAMPS e seus convênios priorizados e melhor delineados. Também se apresenta a idéia clara de que a atenção à saúde deve ser desenvolvida de maneira integrada com a educação.

\section{Quanto à relação do trabalho desenvolvido pela instituição}

e a política de saúde atual percebem-se duas posturas principais: 5 das 8 instituições reconhecem que seu trabalho demonstra o que é possível realizar com essa população e se dispõem a contribuir no que se refere ao atendimento da população desde que respeitada a qualidade do trabalho, sem a imposição de restrições. Também se dispõem a contribuir com formação de profissionais e da própria comunidade. Já outras 02 instituições consideram que poderiam oferecer maior cobertura da clientela caso recebessem maiores recursos públicos o que seria menos oneroso para o Estado do que a criação de novos serviços públicos. Uma instituição entende que poderia haver melhor relação com o setor público, desde que este demonstrasse maior preocupação com a prevenção, detecção precoce e tratamento das deficiências; com a distribuição geográfica dos recursos de atendimento e com a grande rotatividade de seus 
profissionais o que tem invibializado os treinamentos e formação que são desenvolvidos em conjunto com o setor público já há alguns tempo.

Percebemos, que existe, em geral, uma postura aberta das instituições para discutir formas de colaboração com o serviço público, com o SUDS; como algumas até já vêm realizando. Enfim essa seria sua forma de inserção principal na política de saúde atual. Ao mesmo tempo existe um esforço por parte de outras para fazer com que o trabalho que desenvolvem seja integrado à política de saúde via revisão e ampliação de seus convênios com o setor público.

\section{3 - Entrevistas Realizadas com Profissionais da Área Federal}

Foram realizadas 3 entrevistas, usando 0 roteiro de entrevista 6, com representantes do Centro de Reabilitação Profissional do INPS, do PAM Várzea do Carmo, do PAM Maria Zélia do antigo INAMPS.

É importante ressaltar que desses três serviços apenas um - 0 Centro de Reabilitação Profissional do INPS -, não está vinculado ao SUDS. Os outros dois serviços estão vinculados ao SUDS, sendo referência de atendimento para algumas regiões.

O trabalho desenvolvido nos dois serviços, já regionalizados, é centrado prioritariamente na assistência médica, configurando-se como um ambulatório de especialidades.

Desde 1980, um desses serviços - o PAM Várzea do Carmo desenvolve, além do ambulatório de especialidades, um trabalho ligado à reabilitação simplificada: o Serviço Social juntamente 
com o Serviço de Fisioterapia acompanha aqueles segurados ou seus dependentes que necessitam de próteses e órteses (de membros inferiores, coletes, entre outras) e que são acompanhadas pela clínica de Fisiatria e Ortopedia. É dada preferência ao treinamento e adaptação de uso das próteses e órteses daqueles casos que apresentam sequelas simples como as resultantes de acidente vascular cerebral, paralisia infantil, escoliose e cifoses e amputações de membros inferiores; desde que não sejam consequência de acidente de trabalho.

O PAM Maria Zélia, que existia desde 1985, desenvolve o atendimento nas diferentes especialidades médicas incluindo ortopedia, fisiatria e neurologia. Conta com um setor de fisioterapia totalmente equipado para atendimento de pessoas portadoras de lesões neurológicas e ortopédicas, mas não dispõe de profissional fisioterapeuta contratado para o acompanhamento da clientela. Existiu uma tentativa de contratação do profissional pelo SUDS, mas a jornada de trabalho e o salário oferecidos pelo vínculo estadual impossibilitaram a permanência do profissional, pois este cumpria jornada de 8 horas diárias de trabalho, enquanto que os demais tinham jornada de 6 horas e salário muito superior ao oferecido pelo vínculo estadual.

O Centro de Reabilitação Profissional do INPS que funciona em prédio anexo ao do PAM Maria Zélia é responsável pela reabilitação profissional, principalmente, daqueles segurados que se acidentam no trabalho, não atendendo os seus dependentes. Atualmente vem-se realizando um esforço para incorporar ao trabalho os segurados que se encontram em auxílio-doença, isto é, afatados do trabalho por doença, seja ela de nexo causal 
reconhecidamente ligado ao trabalho ou não. Nesse centro não se desenvolvem ações de saúde e quando a clientela necessita desse atendimento é encaminhado aos postos de assistência médica.

Os entrevistados desses serviços entendem que o papel que estas instituições desempenham na atenção à saúde da pessoa portadora de deficiência está diretamente ligado ao tipo de assistência que desenvolvem, isto é: - seria papel de uma delas trabalhar com a reabilitação profissional das pessoas acidentadas de trabalho, que não apresentam grandes incapacidades como cegueira, paraplegia entre outras. Seria papel de outra realizar a assistência de saúde em geral também dessa clientela, nas especialidades médicas de que dispõe ou ainda aquela que desenvolve ações simplificadas de reabilitação teria papel de referência no município para essas ações, apesar de sua reduzida capacidade de atendimento.

$\mathrm{Na}$ questão sobre como deve se inserir a atenção à saúde da pessoa portadora de deficiência no sistema de saúde as opiniões colocam diferentes aspectos: inserção sem discriminação, em todas as UBS, pois se aponta a descentralização do atendimento como fator importante para facilitar o acesso da clientela aos serviços. Ao mesmo tempo, deve-se-ia dar prioridade a essa população; - através de maior dotação orcamentária das unidades que já desenvolvem algum tipo de ação, da contratação de profissionais e da ampliação de espaço físico de trabalho. Assim haveria uma expansão dos serviços já criados. Finalmente, a inserção dar-se-ia a partir da criação de novos serviços, que 
tenham estrutura para atendimento dessa população e não da simples adaptação ou mudança dos objetivos daqueles serviços já existentes.

Quando apresentada aos entrevistados a questão sobre qual é a relação do trabalho desenvolvido com a política de saúde atual, o técnico do Centro de Reabilitação Profissional informou que com a implantação do SUDS e a indefinição, até aquele momento, das leis ordinárias do sistema único de saúde, havia certa insegurança sobre o seu papel, pois se perdeu a referência institucional para as questões específicas do trabalho, que ora parecia ser o SUDS, ora o próprio INPS em nível federal. Existia um esforço esplícito dos profissionais do Centro de Reabilitação de permanecerem ligados ao nível federal, o que representava maior segurança quanto a continuidade do trabalho até ali desenvolvido. Ficou claro o receio de que a ligação com o nível estadual, via SUDS, descaracterizasse o Centro de Reabilitação Profissional de referência para o município o que, rapidamente, comprometeria sua dinâmica e qualidade do trabalho. Já no posto que desenvolve as ações simplificadas de reabilitação, que é serviço de refêrencia para a Grande São Paulo e algumas cidades do interior, reconheceu-se a necessidade de ampliação de sua equipe de profissionais e da criação de novos serviços para cada região do município. Dessa forma haveria possibilidade de acompanhar o trabalho geral de regionalização, hierarquização dos serviços, a que se propõe a política de saúde atual.

Ou seja observamos que as iniciativas de atendimento à saúde 
da população portadora de deficiência nos postos de atendimento médico do antigo INAMPS são fruto do trabalho de alguns profissionais ligados à questão e não são resultados de preocupação institucional com atendimento a essa população.

Já o trabalho do Centro de Reabilitação Profissional é resultado de uma diretriz institucional do próprio INPS, que regulamenta o funcionamento desses serviços, apesar de ser um único serviço no município, referência para a Grande São Paulo e algumas cidades do interior.

\section{4 - Entrevistas Realizadas com Profissionais da Rede Municipal de Saúde.}

Foram realizadas 3 entrevistas usando 0 roteiro de entrevistas 6.

Os profissionais entrevistados revelam que os serviços municipais de saúde têm compromisso com o conjunto da população, mas por outro lado dispõem de uma pequena rede de serviços com capacidade instalada para atendimento entre 7 a 10\% da população municipal, que somados aos demais serviços públicos, tanto federal quanto estadual, têm condições de oferecer atendimento a aproximadamente $20 \%$ da população da cidade.

Os serviços prestados pela rede municipal relacionam-se a atendimento de emergência: (pronto socorro, pronto-atendimento) e atividades programadas, quer por problemas de maior relevância em saúde coletiva (Saúde do Trabalhador, Saúde Mental, Saúde Bucal e AIDS) quer por faixa etária como: Saúde da Criança e ainda Saúde da Mulher.

O financiamento dos serviços é feito a partir do orçamento 
municipal sendo que o repasse de verbas federais está em atraso desde 1989 o que significa em janeiro de 1990 uma dívida de NCz\$ 350 milhões de cruzados novos. Isto sem falar na municipalização, que vem sendo protelada pela Secretaria Estadual de Saúde. A saúde é área de prioridade nesta gestão municipal, sendo a secretaria que maior número de contratações de profissionais realizou em 1989, para colocar em funcionamento a rede de serviços já existentes e as unidades recém-construídas.

Respondem que o papel que essa rede municipal desempenha na atenção à saúde da pessoa portadora de deficiência é atendê-la na rede básica em suas necessidades gerais, é desenvolver ações de prevenção e detecção precoce de deficiência na infância, principalmente, deficiência visual e problemas de aprendizagem através do trabalho das UBS e das Clínicas de atendimento psicológico. Quando é realizado o diagnóstico da deficiência essa população normalmente é encaminhada para os serviços melhor estruturados para o atendimento sejam públicos ou privados.

Existe apensa um hospital próprio do município que desenvolve ações de recuperação e tratamento de pessoas com lesoes neurológicas ou ortopédicas, somente com aquelas que passaram por internação naquele serviço. Também tem sido papel desses serviços desenvolver a discussão desse problema junto à população portadora de deficiência a partir dos princípios de equidade, universalização, descentralização das ações e participação em gestão tripartite: representante da administração, dos funcionários e da população.

Sobre como deveria se inserir a atenção a essa população 
no sistema de saúde os profissionais consideram que isto deveria ocorrer juntamente com as ações de saúde para as demais pessoas respeitando suas especificidades e priorizando as ações de prevenção, detecção precode de deficiência, bem como 0 treinamento de recursos humanos. Existe até a idéia de se assumir a proposta de atendimento da Secretaria Estadual, mas com envolvimento direto dessa população para que se possa obter os recursos necessários e algum nível de prioridade. Propõe-se que esse problema seja considerado problema de saúde coletiva, devendo ser analisado a partir do referencial epidemiológico com propostas de acompanhamento que incluam as UBS no tem e onde estas devam ser previamente preparadas para isso.

Quanto à relação do trabalho desenvolvido por essa rede e a política de saúde atual os profissionais apontaram que a própria política de saúde da administração municipal é contre-hegemônica com o nível federal, pois este tem implantado uma proposta hospitalocêntrica e medicalizadora em complexidade. Isto é, uma política que reflete $o$ setro saúde como um dos setores concentrados de capital na estrutura econômica capitalista e que por isso acumula maiores lucros à medida que incorpora maior tecnologia, ou seja ações de maior complexidade. Assim, o trabalho dessa secretaria tem sido o de implantar sua própria política através dos serviços próprios e de exercer pressão junto aos poderes legislativos e executivo para que se cumpra o texto constitucional.

Percebe-se então, que na rede municipal de saúde as ações junto à população portadora de deficiência são pontuais, não se 
apresentam de forma mais constante nas diferentes regiões e necessitam ser consideradas como um problema de saúde a ser discutido e tratado no interior da própria rede. Isto é, é necessário transformar esse tema em questão relevante para a política municipal de saúde.

\section{2 - Análise dos Resultados das Entrevistas e Conclusões}

As entrevistas realizadas revelam que o tema da atenção à saúde da pessoa portadora de deficiência está presente para a maior parte dos profissionais envolvidos, seja no interior das instituições filantrópicas; seja nos serviços públicos. No entanto, essa presença se coloca de diferentes maneiras: nas instituições públicas os profissionais dos diferentes níveis hierárquicos consideram que a atenção à saúde dessa população é tema pertinente ao serviço público, mas avaliam que as condições concretas de consolidação dessa proposta não se dão, basicamente, por falta de recursos, tanto materiais, quanto financeiros e humanos. Já nas instituições filantrópicas os profissionais consideram que a assistência, propriamente dita, se desenvolve quase que independentemente do setor público, apesar de terem parte de seus custos financiados por verbas públicas.

Em nenhum momento, exceto na fala de uns poucos profissionais que atendem à clientela, existem uma reflexão sobre a pessoa portadora de deficiência, essa clientela, essa parcela da população que pode vir a usufruir desse serviço público ou que já usufrui dos serviços filantrópicos. Quem são essas pessoas? Qual é o seu perfil? Sob quais condições de vida se encontram? Qual é a sua inserção social? 
Parece fundamental que para o melhor desenvolvimento de propostas de atenção à essa população, essas questões devam ser respondidas no interior de cada uma dessas instituições. Isto porque o pensar a política de saúde em geral, e mesmo a política de atenção a essa população em particular, tem que ter como referencial a população em cujo interior se encontram as pessoas já referidas.

O mais comum foi referir-se à clientela dos serviços, tanto filantrópicos quanto públicos, como "carente, de baixo nível socio-econômico ou sem poder aquisitivo. Isto também se aplica aos demais usuários dos serviços de saúde em geral e principalmente daqueles que têm convênios com o setor público.

Dessa forma se estabelece um padrão de relacionamento entre o serviço e o usuário a partir daquilo que ele não tem; ele não tem saúde, não têm "eficiência", por isso deficiente. Ele também não têm condições sócio-econômica para comprar ou pagar, novamente, o serviço que lhe é prestado e nem ao menos para chegar até o serviço. Então parece até normal a usual falta de recursos para o investimento neste tipo de atendimento no setor público: falta espaço físico adaptado para a clientela, faltam recursos humanos e financeiros para a criação ou mesmo para a implementação dos serviços já existentes. Ou, ainda, os valores pagos pelos convênios são insuficientes para atender uma clientela maior. As filas de espera nas instituições aumentam, não existe recursos para ampliação desses serviços, que padecem de déficits financeiros crônicos, pelo menos oficialmente.

As entrevistas ainda revelam que é quase unânime a idéia de que as pessoas portadoras de deficiência devam ter acesso aos 
mesmos serviços que as demais, tanto para as ações de saúde em geral quanto para aquelas ações que podem contribuir com a superação de suas dificuldades específicas. Isto demonstra que a questão da equidade está colocada como um dos aspectos para garantia do direito universal à saúde. No entanto, ainda predomina o argumento da falta de recursos para investimento no atendimento à saúde dessa clientela ou o argumento de que a prioridade dos serviços públicos tem sido a implantação dos pronto-atendimento nas UBS, prática que assim generalizada termina por inviabilizar quaisquer ações de saúde para as quais se supõe um nível mínimo de continuidade.

Priorizar uma rede de serviços públicos baseada no pronto atendimento é mais uma vez colocar uma negativa para o atendimento dessa população. Isto porque em suas necessidades gerais de saúde não estará sendo atendida, apenas aliviada. Ao mesmo tempo que não haverá espaço concreto para as suas necessidades de tratamento ou reabilitação.

As concepções de política de saúde, de inserção da atenção à saúde da pessoa portadora de deficiência no sistema de saúde, se apresentam de tal forma unânimes, que nem mesmo no interior do Grupo de Trabalho que lida especificamente com a saúde da pessoa portadora de deficiência aparecem traços de uma reflexão que vá para além da questão do direito à saúde, da necessidade de garantia desse direito e das dificuldades de implementação das propostas concretas da política principalmente do SUS. No máximo se identifica que existem diferentes concepções dos princípios básicos de descentralização e regionalização, mas essa discussão não é aprofundada a ponto de se perceber que as concepções 
divergentes não são relativas ao modo de operacionalização dos princípios e sim à compreensão de como se deu o processo histórico que vai incorporando os princípios, quais suas bases, seus atores, enfim seu significado na história do país. Pois o que predomina é que a partir da idéia de criação de um sistema único de saúde ou de sua concretização, via SUDS; a implantação dessa proposta só não é possível pela ausência ou insuficiência de recursos, principalmente os financeiros.

As entrevistas também procuraram rastrear questões mais específicas como a relação do programa de atendimento à saúde e reabilitação dessa população e os demais programas ou ações de saúde desenvolvidas nas unidades. As respostas revelaram que, no geral, a relação entre programas se dá através do desenvolvimento de ações conjuntas, ditas de prevenção, realizadas por grupos de profissionais, geralmente profissionais não-médicos. Estas ocorrem junto à clientela que já está na UBS sejam os desnutridos (quando se procura reconhecer aqueles com retardo no desenvolvimento neuropsicomotor e trabalhar a sua estimulação, via grupo de mães ou de atendimento às próprias crianças) sejam os hipertensos e diabéticos (quanto se procura discutir e orientar para o não aparecimento das complicações comuns a essa doença crônico-degenerativa). Esses são alguns dos exemplos relatados como de integração entre programas; integração da equipe multiprofissional nas atividades da UBS ou superação da existência de programas. Os programas em sí são considerados como práticas que isolam, não dão uma visão de saúde integral e não revelam uma prática avançada e mais moderna dos profissionais.

Mais uma vez não se enfrenta claramente essa questão da 
prevenção, pois sempre podemos realizar a prevenção seja de maiores agravos, seja de sequelas ou de incapacidades mais permanentes. No entanto, a questão da prevenção primeira, ou primária sempre permanece fora da esfera da saúde e da ação das UBS. Trabalha-se de dentro da UBS para dentro da própria UBS.

Assim, para os entrevistados parece mais moderno e avançado, na prática, trabalhar a integração e a prevenção dessa maneira pouco produtiva, onde o que termina por ocorrer é a lúcida não adesão da clientela a essas propostas que estão desvinculadas da sua realidade e desprovidas de significado, pois tornam-se encontros em que se prioriza a discussão dos hábitos de vida, mas onde, possivelmente não se discuta a vida real, de pessoas reais.

Esse discurso de integração entre programas com as práticas já apresentadas, termina po impedir que a clientela real, portadora de lesões leves ou graves, com incapacidades que limitam as atividades do cotidiano, tenha acesso aos serviços. Assim torna-se mais longínqua a possibilidade de integração dos programas, a questão da equidade, enfim do direito universal à saúde. Isto porque mais uma vez o parâmetro para o acesso ao serviço será o da normalidade ou da incapacidade leve, que facilitam o desenvolvimento de ações integrais, mas que, no entanto, impossibilitam a adesão dessa população que, pelos princípios gerais colocados nos depoimentos, deveria ter direito a assistência de forma integrada com o restante da população e inclusive nos mesmos serviços.

Essa é uma maneira velada de forçar a que essa população procure as instituições filantrópicas, que não assumem como sendo seu papel trabalhar para o desenvolvimento de uma política de 
atenção à saúde ou para sua própria integração com a política de saúde, proposta hoje. Estas instituições mantém-se estritamente no papel de investir e desenvolver o trabalho de reabilitação e de sensibilização da comunidade para a problemática da pessoa portadora de deficiência sob a sua ótica. Ao mesmo tempo algumas delas consideram que também podem contribuir, e algumas vêm contribuindo até com o próprio serviço público, para a formação de recursos humanos capacitados para o desenvolvimento da assistência a essa clientela. No entanto, essa capacitação terá como norte o próprio trabalho por elas desenvolvido, que é resultado de seu papel no contexto de atenção. Ou seja, são instituições peculiares, que representam experiências de atendimento que, muitas vezes, favorecem a segregação e a estigmatização dessa população (pois lidam apenas com essas clientela), não por intenção explícita de seus profissionais ou dirigentes; mas por sua inserção social. Não cabe a elas, porém, a responsabilidade que cabe ao pode público.

Assim, torna-se necessário que no interior do setor público se repense a integração interinstitucional como medida fundamental para o reodenamento dos serviços de saúde tanto públicos quanto privados. Isto seria a implementação do sistema único de saúde, conforme está proposto no texto constitucional. Até o presente momento a integração interinstitucional, não tem condições de se efetivar na prática, no Município de São Paulo, porque um instrumento primordial para sua consolidação seria a municipalização dos serviços de saúde, problema cuja solução, vem sendo retardada, porque envolve, entre outras questões, o embate política de concepções diferentes de sistema único de 
saúde por parte do governo estadual e municipal.

Enquanto a municipalização dos serviços de saúde, no Município de São Paulo, não for uma realidade não haverá integração das diferentes instâncias - federal, estadual e municipal, ao mesmo tempo que o papel da rede privada será determinado por ela própria, com seu grande poder de pressão, por deter a maior parte dos serviços de saúde, como vem ocorrendo nos últimos anos.

Ao mesmo tempo é urgente que se possa melhor definir o papel inclusive das UBS, que seriam a porta de entrada do sistema único, mas que, atualmente, tem se transformado nos espaços de ampliação do pronto-atendimento, como se esta fosse a maior necessidade da população em geral, conforme revelou depoimento do gerente de região de saúde. É necessário se repensar o perfil das UBS sua função no SUS e as práticas possíveis de serem desenvolvidas no seu interior, inclusive as de atenção à população portadora de deficiência. Repensar o papel das UBS é poder refletir sobre a superação da dicotomia curativo/preventivo que está representada, hoje, pela oposição entre pronto atendimento e atividades dos diferentes programas de saúde. Esse repensar deveria ser fruto da reflexão sobre as necessidades de saúde da população, qual é a sua condição de vida e o que espera desses serviços. Dessa forma poder-se-ia compreender qual é o papel de práticas hoje desenvolvidas - tanto as de pronto atendimento, quanto a dos diferentes programas, inclusive as relativas à população portadora de deficiência. Assim, seria possível fomentar ações que facilitem os esforços de integração social da população em geral e das pessoas portadoras de 
deficiência em particular. Assim, poderia ser superada a questão da integração dos diferentes programas, que da forma como foi colocada pelos entrevistados é extremamente abstrata.

Também é possível depreender-se das entrevistas, principalmente as dos profissionais que atendem a clientela, uma preocupação mais concreta com a qualidade do atendimento prestado, uma angústia constante com as condições de trabalho. A política salarial atual, que determina salários incompatíveis com a necessidade de se aperfeiçoar tecnicamente e de ter condições mínimas de vida. A política de recursos humanos possibilita a existência dos diferentes vínculos de trabalho federal e estadual com diferentes jornadas de trabalho e salários nos mesmos locais de trabalho o que inviabiliza qualquer solução mais concreta das questões de integração interinstitucional. A essas preocupações se acrescenta 0 fato de trabalharem com insuficiência de materiais e equipamentos e com equipes técnicas incompletas o que inviabiliza o atendimento da clientela com os padrões mínimos propostos pelo próprio programa de atendimento à clientela portadora de deficiência.

O fato desses profissionais não apresentarem vivência profissional em saúde coletiva é problema perfeitamente esperado, já que a iniciativa de atendimento a essa clientela nas UBS é recente. É responsabilidade das direções regionais, das coordenações de programas nos SUDS e dos grupos de assessoria do Secretário propor estratégias para lidar com a questão. Os profissionais que estão na linha de frente estão sensibilizados pela problemática da clientela e vêm criando formas de atendê-la calcados em sua experiência anterior. Se estas formas não são as 
mais adequadas, do ponto de vista da saúde coletiva, cabe aos profissionais dos outros níveis criar condições para que 0 atendimento à clientela possa se dar de outra forma. Não se pode imputar aos profissionais das equipes de reabilitação a dificuldade de implantação da proposta, porque vêm trabalhando naquilo para que foram contratados.

Sabe-se também que a perspectiva do atendimento com base nos princípios da saúde coletiva não está presente no funcionamento da maior parte das UBS e que esse mesmo problema está colocado para a maior parte dos profissionais de saúde.

Nas entrevistas, pode-se perceber que os profissionais que atendem à clientela são os que conseguem detectar com maior clareza os problemas relativos à implantação do programa e, apesar de não possuírem formação específica em saúde coletiva, definem e percebem os problemas da política de saúde e de organização dos serviços de saúde da mesma forma que aqueles que têm responsabilidade diferente no delineamento e concretização dos planos e programas de saúde: como os dos diferentes Gepros, diretores de SUDS e coordenadores do programa. Estes estão confusos entre política de saúde, programação e implantação de propostas, recursos insuficientes e falhas organizacionais; questões que quando colocadas ou percebidas indevidamente terminam por confundir a eleição de estratégias adequadas para a resolução dos problemas.

Após essa série de entrevistas pode-se perceber que a inserção da atenção à saúde da pessoa portadora de deficiência no sistema de saúde no município se dá de forma absolutamente marginal. 
Por parte da iniciativa privada de caráter filantrópico e beneficente tem ritmo próprio de funcionamento e mesmo dependendo de financiamento do setor público, este não interfere no curso de seu desenvolvimento.

Por parte do setor público, apesar de no nível da Secretaria Estadual de Saúde haver proposta de sistema de atendimento já delineada e que tem por base os princípios do SUS: (equidade, integralidade das ações, descentralização, regionalização e hierarquização dos serviços) o atendimento à clientela depende quase que, exclusivamente, da ação cotidiana de alguns poucos profissionais diretamente envolvidos nesse atendimento. Isto porque, apesar das direções regionais e coordenações de programa reconhecerem as necessidades de saúde dessa clientela, as ações concretas desses níveis hierárquicos são no sentido de viabilizar as propostas de atendimento prioritárias da Secretaria, onde não se inclui a pessoa portadora de deficiência. Assim, a proposta de atendimento a essa clientela é sempre protelada, a destinação de recursos não é pensada a curto, médio e longo prazo. No nível da Secretaria Municipal de Saúde existem apenas ações pontuais de prevenção e detecção precoce de deficiências e as ações de tratamento e reabilitação inexistem como política em sí, estando restritas a um único serviço em hospital geral.

Apesar de no nível federal existir o delineamento de uma proposta de reabilitação, mesmo que apenas profissional, a existência de um único serviço para a Grande São Paulo e algumas cidades do interior inviabiliza a possibilidade de se pensar em integrá-lo a uma proposta de sistema de atendimento como a delineada pela Secretaria de Estado da Saúde. Ou seja, não 
existem diretrizes mínimas de atendimento a essa parcela da população que a curto, médio ou longo prazo poderiam delinear uma política de atenção à saúde dessas pessoas. Além do que o Gepro Saúde do Deficiente não se configurou como o grupo de acessoria com poder para propor, organizar e viabilizar o desenvolvimento de uma política visto que a implantação do atendimento dependia muito mais da opção do nível regional (SUDS) do que do nível central. Dessa forma também foi dificultada a integração interinstitucional, pois ainda se discutia a municipalização dos serviços de saúde, quais seriam os serviços federais incorporados: tanto é que em algumas unidades de saúde, como na região do SUDS-2, havia serviço com uma chefia para os servidores estaduais e outra para os federais. As dificuldades encontradas para a consolidação do sistema único de saúde, local privilegiado para se lidar com os problemas de saúde coletiva, parecem demonstrar que existem ainda muitos obstáculos a serem transpostos. A estratégia de inserção do atendimento das pessoas portadoras de deficiência na implantação do SUS depende da caracterização das UBS nesse próprio sistema. Assim, a definição ou caracterização de seu perfil deve incluir também o atendimento da parcela da população que é portadora de deficiência, visto que magnitude e importância como problema de saúde coletiva. Dessa forma as UBS devem oferecer condições de acesso a essa população, no mínimo, ao atendimento de saúde nas áreas básicas (pediatria, gineco-obstetrícia e clínica médica).

O atendimento às necessidades específicas dessas pessoas deve obedecer planejamento e programação regionais. Considera-se que as diretrizes gerais da proposta apresentada pelo Gepro Saúde 
do deficiente são acertadas. No entanto, dependem da estruturação das regiões de saúde e da descentralização real do poder no interior da Secretaria de Estado da Saúde. Essas diretrizes devem ser apresentadas e discutidas pelos profissionais que atendem a clientela e pelos representantes das pessoas portadoras de deficiência nas regiões como uma das formas de pressão para que possa fazer parte da prática das UBS e de outras unidades de saúde das regiões. Qualquer proposta de atenção à saúde deve conter um plano de trabalho com objetivos e ações a curto, médio e longo prazo incluindo os diferentes serviços federal, estadual e municipal. Nesse plano de trabalho, que é parte do planejamento e programação de uma determinada região de saúde, devem estar explicitados os recursos humanos, materiais e financeiros próprios para tal, para que este possa se desenvolver com possibilidades mais reais de se consolidar. Segundo THOMPSON (37) só será possível a implantação e implementação de qualquer programa ou proposta de atendimento se esses requisitos básicos forem respeitados.

Muitos serão os entraves encontrados como por exemplo: problemas para integração interinstitucional pois cada serviço desejará manter suas prerrogativas, suas características anteriores; insuficiência de recursos tanto financeiros quanto materiais e humanos, uma das características de todos os programas de saúde enquanto permanecerem esses níveis de investimento no setor. Esses serão problemas a serem lidados no dia a dia da implantação e implementação da proposta pela equipe de profissionais responsáveis. No entanto, sendo proposta assumida pela região de saúde e com recursos próprios existirá 
maior autonomia e possibilidade de êxito do que o que vem ocorrendo no presente momento.

As entrevistas também apontaram a necessidade de que os profissionais que compõem a equipe de reabilitação tenham formação em saúde coletiva. Essa formação deve levar em conta, principalmente a desinformação desses mesmos profissionais sobre a complexidade da rede de serviços públicos, sobre as propostas de atendimento à saúde da população neles desenvolvidas e sobre as condições de trabalho para o desenvolvimento das ações de saúde para as quais foram contratadas. Os técnicos de saúde entrevistados também revelaram surpresa ao perceberem que foram contratados para desenvolver programa de saúde para o qual os próprios gerentes e coordenadores de programa têm pouca clareza de como estes devam ser implantados e implementados.

Assim, considera-se que a formação desses profissionais deve estar voltada para:

- compreender o desenvolvimento da política de saúde como ligada ao desenvolvimento das políticas sociais num país capitalista como o Brasil, cujo desenvolvimento econômico se dá às custas de grande concentração de riqueza e da manutenção da quase totalidade da população em precárias condições de vida e, logicamente, com seu nível de saúde comprometido.

- compreender o desenvolvimento das ações de saúde junto à população portadora de deficiência como resultado desse delineamento das políticas de saúde. Assim, torna-se mais fácil compreender 0 papel das instituições filantrópicas responsáveis pelo atendimento dessa população e pela formação profissional da maior parte dos técnicos dessa área.

- compreender que as ações de saúde e as técnicas específicas de tratamento e reabilitação dessa população têm esse contexto - portanto não são neutras nem ahistóricas.

- compreender que a proposição de ações de tratamento e de reabilitação não deve ser realizada a priori pelos 
técnicos de saúde, onde a triagem dos pacientes funcione como um "funil" tão poderoso que exclua a maior parte da clientela. Isto é, deve-se primeiramente conhecer a demanda regional para, posteriormente, propor as ações. Isto deverá ser realizado de forma a criar diferentes níveis de complexidade no atendimento a essa população para que a rotina de atendimento dos profissionais não se resuma à abertura de vagas numa agenda diária com atendimentos de 30 a 40 minutos individualizados e que se perpetuem por longos períodos, nem sempre com resultados. Os diferentes níveis de complexidade devem compreender ações de busca da população portadora de deficiência, de agrupamento das pessoas com necessidades semelhantes nessa população e de abordagem da problemática específica como por exemplo: alternativas de acompanhamento e tratamento de pessoas com sequelas de doenças neurológicas e com sequelas de acidente de trabalho. Na abordagem específica deve-se priorizar as necessidades apontadas pela clientela como aquelas que devam ser, primeiramente, lidadas, como forma, inclusive, de criar uma estratégia e uma tecnologia de saúde pública na abordagem dessa população onde 0 abandono do tratamento não deve ser visto apenas como falta de recursos financeiros para prover a locomoção até à unidade de saúde, mas também como não adesão da clientela a uma determinada proposta de tratamento.

Essas questões sobre a formação dos profissionais devem ser discutidas com aqueles que já se encontram nos serviços e a elas devem estar agregadas aquelas que esses mesmos profissionais consideram prioritárias. Deve haver um esforço para envolver as instituições de ensino e pesquisa tanto na formação quanto no registro e reflexão das experiências concretas de atendimento, talvez a partir de projetos docente-assistenciais.

A participação da população portadora de deficiência na proposição, acompanhamento e avaliação das propostas de atenção é fundamental para que se crie o espaço institucional necessário para a questão seja priorizada nos serviços de saúde. Faz-se necessário ampliar significativamente a pressão social exercida por essa parcela da população, por suas entidades representativas e pela sociedade civil, sobre o poder público em suas diferentes 
instâncias, para que a atenção à saúde dessas pessoas possa ser considerada problema de saúde. E mesmo assim, esse é apenas um dos aspectos de vida com estreita relação com os demais direitos sociais desses cidadãos. 
VII - CONSIDERAÇÕES FINAIS 
Foi possível sistematizar algumas informações acerca da atenção à saúde da população portadora de deficiência, introduzindo esse tema como uma questão de relevância para a saúde coletiva.

A inserção da atenção à saúde dessa população nos serviços públicos de saúde mostrou-se bastante frágil e marginal, dependendo do esforço individual de alguns profissionais preocupados com a questão e não sendo consequência de um planejamento específico para a área. Foi amplamente propagada como uma questão de direito, a exemplo dos textos constitucionais e dos textos oficiais definidores das ações de saúde e inclusive nos depoimentos dos profissionais nela envolvidos.

Pode-se concluir que o que tem ocorrido é o desenvolvimento da atenção como responsabilidade prioritária das instituições beneficentes e filantrópicas, que tendem, em sua grande maioria, a lidar com essas pessoas como cidadãos que têm a todo momento que provar que necessitam ser atendidos, ou por que têm uma deficiência grave e/ou porque são pessoas "carentes", de baixo poder aquisitivo. Essa lógica não corresponde a do direito social aproximando mais essas pessoas daquela concepção de cidadania invertida descrita.

Apesar dessas próprias instituições e até dos serviços públicos dependerem de financiamento público, com parcela recolhida das contribuições dos salários dos trabalhadores, ; a cidadania regular não se aproxima dessa população. Isto porque, a insuficiência de serviços acaba colocando como justificativa para o atendimento, a necessidade de classificação sócio-econômica e a limitação do número de vagas, que faz com que a população tenha 
que provar a todo momento que necessita, tanto pela impossibilidade ecônomica de custear o atendimento quanto pela gravidade objetiva da incapacidade ou deficiência. Assim, instituições pública e privada têm dinâmica semelhante.

A concepção de cidadania plena em que se baseiam os textos oficiais está deslocada da realidade do atendimento, torna-se muito mais um marco para nortear a pressão social dessa população sobre as autoridades e uma bandeira dos profissionais comprometidos com o estabelecimento de outro ordenamento de prioridades no âmbito da saúde. Ou seja, aquele que advenha das necessidades de saúde da população e não da necessidade de lucro ou reconhecimento social das instituições tanto particulares quanto beneficentes.

A inserção frágil e marginal, da atenção à saúde das pessoas portadoras de deficiência no sistema de saúde e em especial nos serviços públicos, favorece a que essa atenção se reitere cada vez mais como legitimadora de práticas que isolam e segregam essas pessoas, pois acabam por se desenrolar quase que exclusivamente no âmbito de instituições que trabalham apenas com essa população e que não conseguem, na prática, a tão propagada inserção social, meta final de suas propostas de atendimento.

O entendimento deste tema como pertinente à saúde coletiva, se dá pelo fato de que os dados epidemiológicos, mesmo que insuficiente, revelam um contigente populacional que, entre outros aspectos, não tem acesso à atenção à saúde e dela necessita. Assim, o modelo assistencial necessário para que se organize a assistência a essa população deve ser aquele que contemple o planejamento em saúde no qual as ações e os serviços 
são organizados o mais próximo possível da região de moradia das pessoas, através de uma rede de serviços que possa oferecer tanto atendimento básico quanto ambulatorial e hospitalar. Isto é o proposto pelo SUS. Nesse caso, os profissionais devem ser preparados tecnicamente para o atendimento, como também para desenvolver o que se chamou de consciência sanitária dos usuários e da comunidade juntamente com um atendimento humanizado. Dessa maneira não se pode trabalhar apenas com demanda espontânea, tanto da população em geral quanto da população portadora de deficiência como vem ocorrendo nas unidades de saúde. É necessário que a participação do usuário e da comunidade seja estimulada porque será decisiva para lutar pela garantia dos recursos humanos e financeiros para o desenvolvimento desse modelo e consequentemente para a consolidação do SUS.

Sabe-se também que essa concepção de modelo assistencial pressupõe recursos públicos para os serviços públicos. Assim, as instituições que desenvolvem, tradicionalmente, 0 atendimento às pessoas portadoras de deficiência e que recebem subsídios públicos têm que ser melhor caracterizados no contexto dessa assistência. Umda das dificuldades que se pode encontrar para 0 reordenamento dessa assistência é o fato de que as verbas públicas que subsidiam os serviços filantrópicos e beneficentes são oriundos de programas sociais como os da LBA e FUNABEM que não mais se encontram sob a responsabilidade da Previdência Social e que não são parte dos recursos federais para o setor de saúde repassados aos governos estaduais e aos municípais. Dessa forma é necessário um investimento tanto financeiro quanto material e em recursos humanos específico para a atenção a essa 
população, para que a partir daí se possa discutir o papel dos diferentes serviços, tanto públicos quanto privados no contexto da atenção. Um dos papéis possíveis para a rede de serviços filantrópicos poderia ser 0 de se responsabilizar pelo atendimento das pessoas com quadros mais graves de incapacidade e deficiências, e explicitando esse compromisso nos convênios e concessões de verbas que vêm ocorrendo e que possam vir a ocorrer. Dessa forma, caberia ao setor público trabalhar para que a outra parcela dessa população possa ser atendida, principalmente, na rede básica.

Também é urgente se considerar que o estabelecimento de atenção à saúde de um grupo da população pressupõe um nível de planejamento em saúde capaz de prever e estabelecer metal, que para sua concretização tenha definidos a priori os recursos tanto financeiros quanto humanos a curto, médio e longo prazo. Não é possível trabalhar-se apenas anexando ao quadro geral supostas prioridades que nunca se concretizam, porque não são assim consideradas e tratadas nas esferas de poder dos serviços e têm sempre que entrar na "divisão do bolo", já pequeno, dos recursos existentes.

Da mesma forma, a implementação de uma proposta de atenção à saúde da população portadora de deficiência depende, diretamente, da integração interinstitucional dos serviços que, por sua vez, só será possível a partir da municipalização dos serviços de saúde. Dessa forma, sob comando único, de forma descentralizada e hierarquizada será mais real a definição de uma política de atendimento a essa população, no município. Essa política deverá ser capaz de: 
- favorecer a integração interstitucional, rede federal, estadual e municipal respeitando a capacidade de atendimento dos serviços tanto públicos quanto privados já existentes e implementando com os recursos necessários aqueles serviços públicos com capacidade ociosa como no PAM Maria Zélia. Essa integração deve passar pelo delineamento de um tipo único de contrato e jornada de trabalho para os profissionais, pois é impossível continuar a se trabalhar com os diferentes contratos e jornadas de trabalho no interior dos mesmos serviços.

- criar os serviços necessários a essa população nos diferentes níveis de complexidade tanto nas UBS quanto em possíveis ambulatórios de especialidades, hospitais gerais e em unidades ou centros de reabilitação.

- criar condições para que as UBS estabeleçam rotinas de trabalho organizadas além da simples assistência médica absorvendo outras formas de atendimento. Por isso, torna-se fundamental a definição do papel e do perfil das UBS, conforme a necessidade de cada região, incorporando a atenção à população portadora de deficiência e superando a dicotomia preventivo/curativo presente nos serviços.

- propor e efetivar ações de saúde capazes de trabalhar com a percepção, detecção precoce, tratamento e reabilitação no contexto amplo dos serviços e da região.

- delinear na prática das unidades a integração do atendimento a essa população, e não apenas como fruto do 
trabalho de diferentes grupos de assessoria no nível central das Secretaria de Saúde. A integração deve se dar no cotidiano do atendimento.

- superar barreiras arquitetônicas.

- facilitar o acesso e disponibilidadde de recursos humanos que possam ser preparados para trabalhar na ótica da construção do SUS com visão e prática profissional no campo de saúde coletiva.

- implementar a participação das instituições de ensino e pesquisa nesses serviços e no SUS.

Finalizando, acredito que só será possível construir uma inserção, menos marginal, da atenção à saúde dessa população no sistema de saúde, quando houver vontade política de efetivar o Sistema Único de Saúde proposto pela Constituição Federal e os seus desdobramentos na Constituição Estadual. É impossível alcançar esse objetivo se as autoridades sanitárias e os profissionais responsáveis pelo delineamento da política de saúde continuarem a considerar que a proposta SUS é o desdobramento natural da proposição do SUDS e que o que se vive hoje é prioritariamente, um problema de insuficiência de recursos financeiros e não de encaminhamento política da proposta para o setor saúde.

Os textos constitucionais federal e estadual falam dos direitos das pessoas portadoras de deficiência, fazem 
proposições específicas para o atendimento em saúde, educação e profissionalização. O mesmo ocorre na Lei Federal de 1989 que dá atribuições às autarquias e serviços públicos no sentido da estruturação da atenção a essas pessoas penalizando aqueles, serviço público ou privado, que discriminam os portadores de incapacidade ou deficiência. No entanto, essas são informações restritas a pequenos grupos e às quais nem mesmo os profissionais de saúde têm acesso. É tarefa devulgá-los amplamente, inclusive no contexto do atendimento à saúde dessas pessoas, para que estas possam organizar-se e fazer cumprir os textos legais nos limites que a ordem social possibilita.

O desenho da atenção à saúde e a outras necessidades dessas pessoas é o reflexo do espaço real por elas ocupado no contexto social. Reflete como que esse grupo tem dificuldades para exercer seus direitos, dificuldade muito maior que a das demais pessoas. Para as pessoas portadoras de deficiência está colocada a luta pela não discriminação, por serviços apropriados às suas necessidades. Assim, sua luta se dá juntamente com a luta de toda a população excluída de melhores condições de saúde, educação e consequentemente de vida mais digna. 
VIII - BIBLIOGRAFIA 


\section{1 - REFERÊNCIAS BIBLIOGRÁFICAS}

1 - ACIDENTES no trabalho. Prev. Dados, Rio de Janeiro, 3(4): 2738, 1988.

2 - BERLINGUER, G. et al. Reforma sanitária: Brasil/ltália. São Paulo, HUCITEC/CEBES, 1988.

3 - BRASIL. Constituição, 1988. Constituição Federal do Brasil: promulgada em 05 de outubro de 1988. São Paulo, Icone, 1988, p. 132: Dos Direitos Sociais (arts. 203 e 204).

4 - BRASIL. Constituição, 1988. Constituição Federal do Brasil: promulgada em 05 de outubro de 1988. São Paulo, Icone, 1988, p. 129-130: Dos Direitos Sociais (arts. 6 e 11ㅇ).

5 - BRASIL. Constituição, 1988. Constituição Federal do Brasil: promulgada em 05 de outubro de 1988. São Paulo, Icone, 1988, p. 129-130: Da Saúde (arts 196 a 200).

6 - BRASIL. Leis, etc. Decreto no 93.481 de 29 de outubro de 1986: Dispõe sobre a atuação da Administração Federal no que concerne às pessoas portadoras de deficiência, institui a Coordenadoria para Integração da Pessoa Portadora de Deficiência - CORDE. Diário Oficial da União, Brasília, 30 out. 1986. p. 16217.

7 - BRASIL. Leis, etc. Decreto no 94.657 de 20 de julho de 1987: Dispõe sobre a criação de Sistema Unificados e Descentralizados de Saúde nos Estados (SUDS). Diário Oficial da União, Brasília, 15 mar. 1990. p. 5364-86.

8 - BRASIL. Leis, etc. Decreto no 99.180 de 15 de março de 1990: Dispõe sobre a reorganização e o funcionamento dos Orgãos da Presidência da República. Diário Oficial da União, Brasília, 15 mar. 1990. p. 5364-86.

9 - BRASIL. Leis, etc. Lei ํㅜ 7.853

10 - BRASIL. Leis, etc. Medida Provisória $n^{0} 150$, de 15 de março de 1990. Dispõe sobre a organização da Presidência da República e dos Ministérios. Diário Oficial da União, Brasília, 15 mar. 1990. P. 5352-59.

11 - BOLETIM DO CONSELHO MUNICIPAL DA PESSOA DEFICIENTE. São Paulo, (2), jan. 1990. 
12 - CAMPOS, G.W.S Modelo assistencial e unidades básicas de saúde: elementos para debate. In: CAMPOS, G.W.S. et al. Planejamento sem normas. São Paulo, HUCITEC, 1989. P. 53-60.

13 - $\mathrm{CONH}, \mathrm{A}$. at al Acidentes de trabalho: uma forma de violência. São Paulo, Cedec, 1985. P. 16-18.

14 - COORDENADORIA PARA INTEGRAÇÃO DA PESSOA PORTADORA DE DEFICIEENCIA - CORDE. $1^{\circ}$ Plano de ação CORDE. Brasilia, s. d. [Mimeografado].

15 - FUNDAÇÃO IBGE. Pesquisa nacional por amostra de domicílios. 1981: Brasil e grandes regiões. Rio de Janeiro, 1983. V. 5, t. 11, p.XXI-XXII, 3, 63-4, 93, 151, 179, 239, 271, 331, 361, 321, $451,511$.

16 - FUNDAÇÃO IBGE. Pesquisa nacional por amostra de domicílios. 1981: Estado de São Paulo. Rio de Janeiro, 1983. V.5, t.6, p.3, 13,63,64.

17 - FUNDAÇÃO IBGE. Pesquisa nacional por amostra de domicílios. 1981: Estado de São Paulo. Rio de Janeiro, 1983. V.5, t.12, p.459,549-50.

18 - FUNDAÇÃO LEGIÃO BRASILEIRA DE ASSISTÊNCIA. Instrução normativa S.A.S. 01/87 de 27 de março de 1987 que regulamenta a prestação de assistência às pessoas portadoras de deficiência pela LBA e pela FUNABEM. Rio de Janeiro, 1987.

19 - FUNDO SOCIAL DE SOLIDARIEDADE DO ESTADO DE SÃO PAULO. Deficiência: profissionalização e microempresas. Meta soc. (7): 40, dez. 1988.

20 - HELANDER, E. et al. Training the disabled in the community - an experimental manual on rehabilitation and disability prevention, for developing countries, Geneva, World Health Organization, 1980.

21 - IBARRA, L. G. \& PEREZ, L. S. R. El registro nacional de inválidos: informe de 24.375 casos notificados. Salud públ. México, 22 (2): 179-89, 1980.

22 - LAUREL, A. C. A saúde - doença como processo social. In: Nunes, E. D. Medicina social - aspectos históricos e teóricos. São Paulo, Global, 1983. P. 133-58.

23 - LIANZA, S. A situação atual de reabilitação no estado de São Paulo. Ver. Paul. Hosp., 30 (1/2): 5-10, 1982. 
24 - MINISTÉRIO DA PREVIDÊNCIA E ASSISTÊNCIA SOCIAL. Secretaria de Previdência Social. Portaria no 07 de 28 de maio de 1987: Dispõe sobre a atualização e sistematização das diretrizes básicas que devem fudamentar as normas e procedimentos dos Serviços Previdênciarios de Reabilitação Profissional, Serviço Social e Perícia Médica. Diário Oficial da União, Brasília, 03 jun 1987. P. 8544-6.

25 - ORGANIZACIÓN MUNDIAL DE LA SALUD. Cumité de Expertos em Prevención de Incapacidades y Rehabilitación, Ginebra, 1981. Informe. Ginebra, 1981. P.7-18. (Série de Informes Técnicos, 668).

26 - PANTANO, L. La discapacidad como problema social - un enfoque sociológico: reflexiones y propuestas. Buenos Aires, EUDEBA, 1987.

27 - POSSAS, C. A. Contribuição para a definição de um sistema nacional de informações em doenças e acidentes de trabalho. Prev. Dados, Rio de Janeiro, 2(2): 13-24, 1987.

28 - SANTOS JR., A. C. S. \& LESSA, I. Prevalência de incapacidades em dois diferentes grupos sociais em Salvador, Brasil. Bol. Ofic. Sanit. Panamer., 106(4): 304-13, 1989.

29 - SÃO PAULO. Constituição, 1989. Constituição do Estado de São Paulo: 5 de outubro de 1989, São Paulo, Atlas, 1990. P. 103-5: Da Proteção Especial (arts. 277 a 281), (Manuais de Legislação Atlas, v. 5).

30 - SÃO PAULO. Constituição, 1989. Constituição do Estado de São Paulo: 5 de outubro de 1989. São Paulo, Atlas, 1990. P.90-4: Da Saúde (arts.219 a 231). (Manuais de Legislação Atlas, v. 5).

31 - SECRETARIA DE ESTADO DA SAÚDE. Resolução no 87 de 12 de dezembro de 1984. Dispõe sobre a criação de grupo de trabalho para estudar e propor sistema de atendimento e reabilitação da pessoa portadora de deficiência. Diário Oficial do Estado de São Paulo, 13 dez. 1984. P. 48.

32 -

Documento básico sobre o sistema de atendimento à saúde e reabilitação da pessoa com deficiência. São Paulo, 1985. [Mimeografado].

33 -

- Grupo Especial de Programa de Saúde do Deficiente. Sistema de Atendimento à saúde e reabilitação da pessoa com deficiência. São Paulo, 1983. [Mimeografado].

34 - SOARES, L. B. J. Terapia Ocupacional: lógica do capital ou do trabalho? São Carlos, 1987. /Dissertação de Mestrado Universidade Federal de São Carlos/. 
35 - SPOSATTI, A. et al. Assistência na trajetória das políticas sociais brasileiras: - uma questão em análise. São Paulo, Cortez, 1987.

36 - TEIXEIRA, S. M. F. Assistência social na previdência social uma política marginal. In: Sposatti, A. et al. Os direitos (dos desassistidos) sociais. São Paulo, Cortez, 1989. P. 31-108.

37 - THOMPSON, F. J. Health policy and the bureaucracy: politics and unplementation. Cambridge, Mass., Mit Press, 1981. 
ABLON, J. Stigmatized Health Condition. Soc Sci \& Med., 15B: 59,1981.

ABRANCHES, S. H. et al. Política social e combate à pobreza. Rio de Janeiro, Zahar, 1987.

BERLINGUER, G. A doença. São Paulo, HUCITEC/CEBES, 1988. HUCITEC/CEBES, 1988.

et al. Reforma Sanitária: Brasil e Itália. São Paulo, BRAGA, J. C. S. \& GRANDA, S. G. Saúde e previdência: estudos de política social. São Paulo, HUCITEC, 1986.

CALDERON, M. V. et al. La programacion em el âmbito de la rehabilitacion, Salud publ. México, 25 (1): 83-88, 1982.

CAPISTRANO, F. D. Saúde para todos: desafio ao município. São Paulo, HUCITEC, 1985.

CARVALHEIRO, J. R. La investigación de necessidades de salud em relación com la prestacións de servicios. Cuad. Med soc., Rosario, (34): 15-23, dic. 1985.

CLARKE, A. K. Community-Based rehabilitation in England. Int. Disabil. Stud., 9 (1): 18-21, 1987.

COHN, A. Previdência social e processo político no Brasil. São Paulo, Ed. Moderna, 1980.

COSTA, N. R. et al (org). Demandas populares, políticas públicas e saúde. Petrópolis, Vozes/ABRASCO, 1989.

COUTINHO, M. Financiamento de programas sociais com especial atenção ao atendimento médico. Ver. Adm. Públ., 21 (2): 5-23, 1987.

DALLARI, D.A. Ser cidadão. Lua nova, São Paulo, 1(2): 61-4, 1984.

DALARRI, S. G. Municipalização dos serviços de saúde. São Paulo, Brasiliense, 1985.

22(1) 57-63, 1988.

. O direito da saúde. Rev. Saúde públ., São Paulo,

DEJOURS, C. Por um conceito de saúde, Rev Saúde publ., São Paulo, 54 (14): 7-11, 1986.

do trabalho. São Paulo, Oboré, 1987.

A loucura do trabalho o estudo de psicopatologia

DURAND, J. C. Profissões de saúde em São Paulo: expansão e concorrência entre 1968-1983. Cad. FUNDAP , 5(10): 4-23, 1985. 
DURHAM, E. R. Movimentos sociais: a contrução da cidadania. Novos Est. CEBRAP, (10):24-30, 1984.

EISSENHAUER, W. \& DESER, E. Post-acute in-patient rehabilitation what's its use ? a statistical view. Rehabilitation, Stuttgart, 27: 1821, 1988.

EVANS, P. et al. Prevalence and disabilities in 4 to 8 years olds with cerebral palsy. Arch. Dis. Child., 60: 940-45, 1985.

FALEIROS, V. P. Política social do estado capitalista - as funções da previdência e da assistência sociais. São Paulo, Cortez, 1987.

FEINBLATT, A. Political activism among physically disabled individuals. Arch. Phys. Med. Rehabil., 62: 360-64, 1981.

FERLAND, F. et al. Programme de sensibilisation à la personne handicapée, realisé un millieu scolaire. Canadi. J. occup. Therap., 48 (5):203-6, 1981.

FLAX. H. J. Opportunities for training of rehabilitation medicine personal in Latin América. Amer. J. phys. Med., 66(5): 244 - 248, 1987.

FRAGA, A. La invalidez - sus causas y repercussion socioeconomica. Gac med. Mexico, 118 (5): 171-85, 1982.

GENTILLE DE MELLO, C. O sistema de saúde em crise. Rio de Janeiro, HUCITEC, 1988.

GHOSH, B. N. et al. Disability prevalence in a urban community in relation to socio-economic conditions. Indian J. med. Res., 80 : 347354, 1984.

GONCALVES, E.L. (org) Administração de saúde no Brasil. São Paulo, Pioneira, 1982.

GREZA, G. The right to prevention, early detection and medical rehabilitation under national and international aspects. Int. J. Rehab. Res., 10(3): 207-275, 1987.

GRIMBY, G. et al. Evaluation of community-based rehabilitation in Punjab, Pakistan. II - The prevalence of diseases, impairments, and handicaps. Int. Disabil. Stud., 10 (2): 59-60, 1988.

HARRINGTON, C. \& NEWCOMER, R. Social/Health maintenance organizations: new policy options for the aged, blind and disabled. J. publ. Hlth Pol. (June): 205-222, 1985.

HELANDER, E. Provision to rehabilitation of the disabled on the community level. Proc roy. Soc. London, 209: 139-40, 1980. 
HERMANOVA, $\mathrm{H}$. Priorities in disability prevention and rehabilitation. Int. Disabil. Stud., 9(12): 61-4, 1987.

HERNANDEZ, A. L. Critérios para el estabelecimento de prioridades de investigación in salud. Educ. med. Salud, 21(3): 193-204, 1987.

HERPICH, M. \& STEINLE, A. Problems of general conditions of industrial integration of disabled person. Rehabilitation, Stuttgart, 22: 149-156, 1983.

INSTITUTO BRASILEIRO DE ANÁLISE SOCIAL E ECONÔMICAS (IBASE) Saúde e trabalho no Brasil, Rio de Janeiro, 1983.

IBARRA - IBARRA, L. G. \& DOMINGUES, L. M. O. Enfermedad aguda, enfermedad crónica y invalidez em la infância em el sector salud del área metropolitana. Salud. Publ. Mexico, 28(2): 161-171, 1986.

IBARRA - IBARRA, L. G. et al. Rehabilitacion del niño inválido. Bol. Med. Hosp. Inf. Mexico, 38 (6): 967-77, 1981.

ILLICH, I. A apropriação da saúde. Rio de Janeiro, Nova Brasileira, 1975.

INFANTE, N. B. Los procesos de trabajo y salud-enfermedad: uma relación dialética. Educ. med. Salud, 21 (2): 92-105, 1987.

JACK, A. et al. The prevalence of physical disability: preliminary results or a Wellington survey. New Zealand med. J., 91 (637): 24346, 1980.

JACOBI, P. Movimentos sociais e políticas públicas. São Paulo, Cortez, 1989.

KEITH, R. A. Observations in the Rehabilitation Hospital: twenty years of research. Arch. Phys. Med. Rehabil., 69 (8): 625-31, 1988.

KORNBLIT, A.L. Pasos hacia la enseñanza del modelo eco-sistemico en Medicina. Med. \& Soc., 10(4): 110-125, 1987.

LEITE, C. B. Cobertura previdenciária do acidente de trabalho. Prev. Dados, Rio de Janeiro, 2(1): 5-12, 1987.

LUZ, M. T. As instituições médicas no Brasil. Rio de Janeiro, Graal, 1979.

Natural, racional, social, razão médica e racionalidade científica moderna. Rio de Janeiro, Campus, 1988.

MARINGER, C.R.T Community-based rehabilitation - the challenge and opportunity. Int. Disabil. Stud., 10(2): 88-9, 1988.

MARSIGLIA, R. et al. Saúde Mental e cidadania. São Paulo, Mandacaru, 1987. 
MEDINA, M.C.G. A aposentadoria por invalidez. São Paulo, 1986./Dissertação de mestrado - Faculdade de Medicina da USP/.

MENENDEZ, E. L. La Salud como derecho humano. Acotaciones sobre la possibildad de una prática diferenciada. Cuad. Med. Soc., Rosano. (37): 19-26,1986.

NAVARRO, V. Classe social, poder político e o estado e suas implicações na medicina. In: TEXTOS de Apoio. Ciências Sociais 1. .2ed. Rio de Janeiro, Programa de Educação Continuada. Escola Nacional de Saúde Pública/ABRASCO, 1986. P. 83-161.

NEWACHEC, P. Y. Financing health care for disabled children. Pediatrics, 81(3): 385-94, 1988.

NOGUEIRA, R. P. Dinâmica do mercado de trabalho em saúde no Brasil, 1970-1983. Educ. med. Salud, 20(3): 335-349, 1986.

NOGUEIRA, L. M. M. D. \& MAYER, C. A. L. Reabilitação Profissional do INPS. Prev. Dados, Rio de Janeiro, 4(1): 5-22, 1989.

OLIVEIRA, F. E. B. Reforma Previdênciaria: avanço social ou ampliação de privilégios?. Ver. Adm. Publ., 21 (4): 62-93, 1987.

OLIVEIRA, G. S. et al. Terapia Ocupacional no centro de saúde de Icoaracy: nossa experiência. Ver. Ass. Bras. Psiq., 6(21): 56-63, 1984.

PAOLINELLI, L. M. Acciones de rehabilitación médica em Chile, 1952-1977. Rev. Méd. Chile, 105: 707-713, 1977.

PASTOR, A. C. Modelos de sistema de atención médica. Salud publ. México, 28 (3):230-264, 1986.

PAZ JR, A. C. Considerações sobre a problemática do incapacitado físico no Brasil. Seara méd. neurocir., 9(2): 237-242, 1980.

PHAROAH, P. O. D. The epideomiology of chronic disability in childhood. Int. Rehabil. Med., 7(1): 11-17, 1985.

PHILIP, R. et al. Prevalence estimate of physical handicap, Publ. HIth, 100: 42-43, 1986.

PINO, S. R. Estado de la nutricion em niños impedidos. Rev. Chil. Pediatr., 58(3): 213-215, 1987.

POSSAS, L. Saúde e trabalho - a crise da previdência social. Rio de Janeiro, Ed. Graal, 1981.

POSSAS, C. A. \& MARQUES, M. B. Subsídios à análise política das propostas de integração entre as instituições públicas de saúde. Rev. Bras. Educ. méd., 8 (2): 83-89, 1984. 
REZENDE, A. L. Saúde dialética do pensar e do fazer. São Paulo, Cortez, 1986.

RODRIGUES, M. I. \& VILLAREAL, R. La administración del conocimento. Lo biológico y lo social em la formación del personal de salud em América Larina. Educ. méd. Salud, 20(4): 424-439, 1986.

SÁ, E. N. C. Notas sobre o setor saúde e saneamento público do Estado de São Paulo para 1987. Ver. Saúde públ., São Paulo, 21(3): 276-278, 1987.

\& RABELLO, M. C. G. Administração por convênios: um instrumento gerencial de políticas. Ver. Saúde publ., São Paulo, 22(2): 150-8, 1988.

Análise de uma organização pública complexa no setor saúde: o conjunto Juqueri, no Estado de São Paulo. São Paulo, 1983. [Tese de Doutorado - Faculdade de Saúde Pública da USP].

SAIDE, O. O conceito de saúde e doença para um projeto de Saúde pública. Inf. Psiq., 4 (2): 27-31, 1983.

SALBREUX, R. et al. Typologie et prevalence des handicaps severes et multiples dans une population d enfants. Neuropsychiat. Enf., 27(1/2): 5-28, 1979.

SEIXAS, J.C. Sistema Nacional de Saúde. In: TEXTOS de apoio. Ciências Sociais 1. 2. Ed. Rio de Janeiro, Programa de Educação Continuada. Escola Nacional de Saúde Pública/ABRASCO, 1986, p. 59-79.

SILVEIRA, P.F. Sobre a deontologia do intervencionismo estatal no setor saúde. Rev. Saúde Publ., São Paulo, 22 (3): 221-32, 1988.

SPOSATI, A. et al. Assistência na trajetória das políticas sociais brasileiras: uma questão em análise. São Paulo, Cortez, 1987.

Paulo, Cortez, 1989.

. Et al. Os direitos (dos desassistidos) sociais. São

SOUZA, J. M. P. et al. Estudo da morbidade e da mortalidade perinatal em maternidade. III - Anomalias congênitas em nascidos vivos. Ver. Saúde publ., São Paulo, 21(1): 5-12, 1987.

STRUFFALDI, M. C. Conhecimento, opinião e conduta de médicosperitos acidentários face à programação do Centro de Reabilitação Profissional do INPS, do Município de São Paulo. São Paulo, 1988. /Dissertação de Mestrado - Faculdade de Saúde Pública da USP/.

TATE, D. G. et al. Women and Disabilities: an international perspective. Rehabil. Lit., 43 (7/8): 222-227, 1982. 
TEIXEIRA, S. M. F. Política social em crise na América Latina. Ver. Adm. Públ., 19(4): 98-129, 1985.

Públ., 20(4): 115-140, 1986.

. Cidadania, direitos sociais e estado. Ver. Adm. . O dilema reformista na reforma sanitária brasileira.

Ver. Adm. Públ.., 21 (4): 94-115, 1987.

THOMPSON, F. J. Health policy and the bureaucracy: politics and umplementation. Cambridge, Mass., Mit Press, 1981.

VASH, C. Enfrantando a deficiência - a manifestação, a psicologia, a reabilitação. São Paulo, EDUSP/Pioneira, 1988.

WALKER, D. K. et al Use and sources of payment for health and community services of children with impaired mobility. Publ. Hlth Res., 103(4):411-5, 1988.

ZAMUDIO, A. T. La paralisia cerebral en México. Salud publ. Mexico, 28(2): 125-133, 1986. 
Membros do Núcleo Operativo do Gepro de Saúde da Pessoa Deficiente

1 - Qual é sua concepção de Política de Saúde?

2 - Qual é, no seu entender, a Política de Saúde que permeia a Secretaria de Estado de Saúde?

3 - Qual é a concepção de Política de Saúde necessária para o desenvolvimento do Programa?

4 - Qual é a relação do programa de atendimento à saúde e reabilitação da pessoa portadora de deficiência com os demais programas desenvolvidos na Secretaria de Saúde?

5 - Qual é a sua avaliação da implantação do Programa e em especial no Município de São Paulo?

6 - Qual é a sua avaliação da implantação do Programa no tocante a insumos e recursos disponíveis?

7 - Quais são as necessidade que você identifica para o melhor desenvolvimento do Programa? 
ROTEIRO DE ENTREVISTAS - 02

Profissional membro da Direção da Unidade de Saúde onde se desenvolve o Programa.

1 - Qual é a sua concepção de Política de Saúde?

2 - Qual é, no seu entender, a Política de Saúde que permeia a Secretaria de Estado da Saúde?

3 - Como você entende que deva se inserir a atenção à saúde da pessoa portadora de deficiência no sistema de saúde?

4 - Como tem se desenvolvido o programa nesta Unidade?

5 - Como se dá a relação do programa de atenção à saúde da pessoa portadora de deficiência e as demais ações de saúde desenvolvidas nessa Unidade?

6 - Qual é sua avaliação da implantação do Programa nessa Unidade?

7 - Sugestões 
ROTEIRO DE ENTREVISTAS - 03

- Profissional que é membro da direção da região

- Profissional que coordena a implantação do Programa na região

1 - Qual é a sua concepção de Política de Saúde?

2 - Qual é, no seu entender, a Política de Saúde que permeia a Secretaria de Estado de Saúde?

3 - Como você entende que deva se inserir a atenção à saúde da pessoa portadora de deficiência no Sistema de Saúde?

4 - Como tem se desenvolvido o programa nesta região?

5 - Como se dá a relação do programa de atenção à saúde da pessoa portadora de deficiência e as demais ações de Saúde?

6 - Qual é a sua avaliação da implantação do Programa nesta região?

7 - Sugestões 


\section{ROTEIRO DE ENTREVISTAS - 04}

Profissionais que desenvolvem atendimento direto da clientela

1 - Qual é a sua formação profissional?

2 - Descreva a sua experiência profissional anterior

3 - O que você considera que seja Política de Saúde?

4 - Qual a sua vinculação ao programa de atendimento à pessoa portadora de deficiência?

5 - O que você espera do Programa de atendimento à saúde da pessoa portadora de deficiência?

6 - Qual é a contribuição que você pode dar ao Programa de atendimento à saúde da pessoa portadora de deficiência?

7 - Descreva o seu cotidiano de trabalho no programa

8 - Descreva a clientela

9 - Sugestões 


\title{
ROTEIRO DE ENTREVISTAS - 05
}

Coordenador de Gepro que está relacionado à problemática da pessoa portadora de deficiência

\author{
Gepro Saúde da Criança \\ Gepro Saúde do Trabalhador \\ Gepro Doença Crônico-Degenerativa \\ Gepro Saúde Mental \\ Gepro Hanseníase \\ Gepro Ortopedia e Traumatologia
}

1 - Qual é sua concepção de Política de Saúde?

2 - Qual é, no seu entender a concepção de Política de Saúde que é desenvolvida pela Secretaria de Estado da Saúde?

3 - Como você considera que deva se inserir a atenção à saúde da pessoa portadora de deficiência no sistema de saúde?

4 - Qual é a relação do programa de atenção à saúde e reabilitação da pessoa portadora de deficiência com o trabalho desenvolvido por esse Gepro?

5 - Qual é a relação do programa de atenção à pessoa portadora de deficiência com os demais programas?

6 - Sugestões 


\section{ROTEIRO DE ENTREVISTAS - 06}

- Representante das instituições que tradicionalmente atendem à pessoa portadora de deficiência

- Profissionais representantes da área federal

- Profissionais representantes da rede municipal de saúde

1 - Como se desenvolve o trabalho nesta instituiçõa quanto a clientela, tipo de atendimento oferecido, financiamento e prioridades institucionais?

2 - Qual é o papel que esta instituição desempenha na atenção à saúde da pessoa portadora de deficiência?

3 - Como deve se inserir a atenção à saúde da pessoa portadora de deficiência no sistema de saúde?

4 - Qual é a relação do trabalho aqui desenvolvido com a política e saúde atual? 